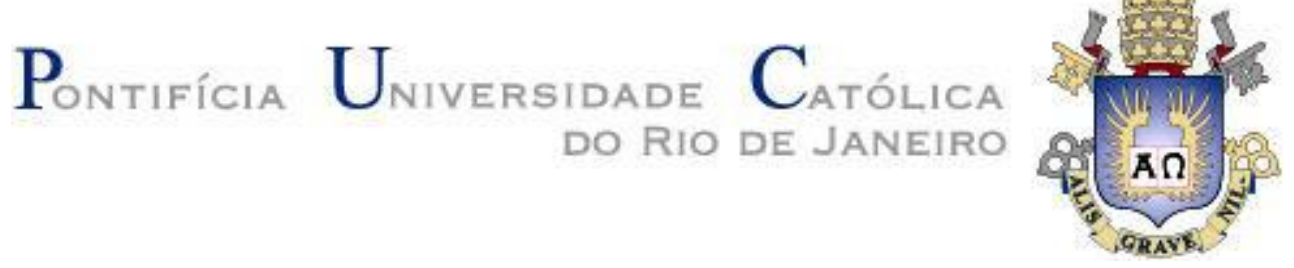

Ana Lucia Amado Saraiva Ribeiro

\title{
A leitura da sarjeta: uma análise da intermidialidade dos quadrinhos
}

Dissertação de Mestrado

Dissertação apresentada como requisito parcial para obtenção do grau de Mestre pelo Programa de PósGraduação em Literatura, Cultura e Contemporaneidade do Departamento de Letras do Centro de Teologia e Ciências Humanas da PUC-Rio.

Orientador: Prof. Karl Erik Schøllhammer Coorientadora: Profa. Danusa Depes Portas 


\title{
Pontifícia Universidade Católlica $_{\text {a }}$ DO RIO DE JANEIRO
}

\section{Ana Lucia Amado Saraiva Ribeiro}

\section{A leitura da sarjeta: uma análise da intermidialidade dos quadrinhos}

\begin{abstract}
Dissertação apresentada como requisito parcial para obtenção do grau de Mestre pelo Programa de PósGraduação em Literatura, Cultura e Contemporaneidade do Departamento de Letras do Centro de Teologia e Ciências Humanas da PUC-Rio.
\end{abstract}

\author{
Prof. Karl Erik Schøllhammer \\ Orientador \\ Departamento de Letras - PUC-Rio \\ Profa. Danusa Depes Portas \\ Coorientadora \\ Departamento de Letras - PUC-Rio \\ Prof. Miguel Jost Ramos \\ Departamento de Letras - PUC-Rio
}

Prof. Messias Tadeu Capistrano dos Santos

EBA /UFRJ

Profa. Monah Winograd

Coordenadora Setorial do Centro de Teologia

e Ciências Humanas - PUC-Rio

Rio de Janeiro, 26 de abril de 2018 
Todos os direitos reservados. É proibida a reprodução total ou parcial do trabalho sem autorização da universidade, da autora e do orientador.

\section{Ana Lucia Amado Saraiva Ribeiro}

Ana Amado fez sua graduação em Antropologia pela Unicamp e UFRJ, e especialização em Publishing management pela FGV e em Filosofia pela UNB, onde, em 2009, apresentou monografia com o tema "O silêncio nas imagens". Em 2016, iniciou seus estudos no mestrado no Programa de Pós-Graduação em Literatura, Cultura e Contemporaneidade da PUC-Rio, dando seguimento ao interesse pelo não-dito e não-mostrado no campo da imagem e do texto verbal. Hoje, atua como roteirista.

Ficha Catalográfica

Ribeiro, Ana Lucia Amado Saraiva

A leitura da sarjeta: uma análise da intermidialidade dos quadrinhos / Ana Lucia Amado Saraiva Ribeiro; orientador: Karl Erik Schøllhammer ; coorientadora: Danusa Depes Portas. - 2018.

126 f.: il. color; $30 \mathrm{~cm}$

Dissertação (mestrado)-Pontifícia Universidade Católica do Rio de Janeiro, Departamento de Letras, 2018.

Inclui bibliografia

1. Letras - Teses. 2. História em quadrinhos. 3. Sarjeta. 4. Intermidialidade. 5. Pintura. 6. Literatura. I. Schøllhammer, Karl Erik. II. Portas, Danusa Depes. III. Pontifícia Universidade Católica do Rio de Janeiro. Departamento de Letras. IV. Título

CDD: 800 
Dedico esta dissertação com amor ao meu filho Gabriel, pelo lindo aprendizado que há 18 anos temos construído. 


\section{Agradecimentos}

Agradeço à orientação de Karl Erik Schøllhammer e à coorientação de Danusa Depes Portas.

Ao CNPq e à PUC-Rio, pelos auxílios concedidos, sem os quais este trabalho não teria sido realizado.

Agradeço ao professor Alexandre Montaury e ao professor Miguel Jost, cujas aulas e o convívio em sala de aula foram valiosas em minha formação,

Agradeço ao professor Tadeu Capistrano, que gentilmente aceitou fazer parte da banca examinadora.

Agradeço a Francisco Camêlo, pelo apoio na reta final.

Agradeço a Sergio Manon, por me contagiar com seu ânimo e amor pelo trabalt Teria sido tudo mais difícil sem você. 


\section{Resumo}

Ribeiro, Ana Amado Saraiva; Schøllhammer, Karl Erik; Portas, Danusa Depes. A leitura da sarjeta: uma análise da intermidialidade nos quadrinhos. Rio de Janeiro, 2018. 126p. Dissertação de Mestrado Departamento de Letras, Pontifícia Universidade Católica do Rio de Janeiro.

A presente pesquisa busca compreender os quadrinhos como expressão que recria conteúdos e formas de outras artes. Em perspectiva interdisciplinar, assumese o viés da intermidialidade, segundo a qual a relação entre as artes é também uma relação entre mídias, para analisar os quadrinhos como forma de expressão que se constitui historicamente a partir de processos que recriam e reapresentam os procedimentos de outras artes, como a literatura e a pintura - e, não, como um sistema autônomo, cujas zonas de contato com outras artes constituem meros cruzamentos de fronteiras bem demarcadas. Objetiva-se também mostrar que a sarjeta, como expediente de montagem nos quadrinhos, oferece um ângulo privilegiado para pensar a intermidialidade, já que, em seus usos mais experimentais e fragmentários, torna menos transparente a relação que os quadrinhos estabelecem com a pintura e a literatura. Este trabalho é composto de duas partes: uma, teórica, que consiste no resgate interdisciplinar de parte da fortuna crítica disponível sobre o tema, e outra parte que constitui um experimento teórico na proposição da escritura de uma história em quadrinhos cuja relação com a pintura e seus textos traz à tona o tema da intermidialidade, e cujos procedimentos de montagem remetem às discussões propostas pela pesquisa. A HQ realizada nesta pesquisa chama-se Jardim das Sinapses - ensaio gráfico biocêntrico, e resulta do trabalho de pesquisa em parceria com o artista plástico e editor Sérgio Manon.

\section{Palavras-chave}

História em quadrinhos; sarjeta; intermidialidade; pintura; literatura. 


\section{Abstract}

Ribeiro, Ana Lucia Amado Saraiva; Schøllhammer, Karl Erik (Advisor); Portas, Danusa Depes (Co-advisor) The gutter reading: an analysis of the intermediality in comics. Rio de Janeiro, 2018. 126p. Dissertação de Mestrado - Departamento de Letras, Pontifícia Universidade Católica do Rio de Janeiro.

This research seeks to understand comics as an expression that recreates contents and forms of other arts. In an interdisciplinary perspective, it assumes the approach of intermediality, according to which the relation between the arts is also a relation between media. This research seeks to understand comics as a form of expression that is historically constituted from processes that re-create and represent the procedures of other arts, such as literature and painting - and not as an autonomous system, whose zones of contact with other arts are mere crosses of well-demarcated frontiers. It is also intended to show that the gutter, as a set-up in comics, offers a privileged angle to think of intermediality, since, in its more experimental and fragmentary uses, it renders less transparent the relation that comics establish with painting and literature This work is composed of two parts: one, theoretical, which consists in the interdisciplinary rescue of part of the available critical fortune on the subject, and another part that constitutes a theoretical experiment in the proposition of the writing of a comic book whose relation with painting and his texts bring to the surface the theme of intermediality, and whose procedures of montage refer to the discussions proposed by the research. The comics manufactured in this research is called Jardim das Sinapses - a biocentric graphic essay, and results from the research work in partnership with the artist and publisher Sergio Manon.

\section{Keywords}

Comics; gutter; intermidiality; painting, literature. 


\section{Sumário}

1. Introdução 11

1.1. Apresentação da pesquisa, como tudo 11

1.2. Estrutura do trabalho 14

2. História em quadrinhos 19

2.1. Breve panorama da dimensão histórica e cultural dos $\quad 19$ quadrinhos no Brasil

2.2. Quadrinhos e seus campos de estudo 22

3. Montagem nos quadrinhos $\quad 50$

4. Quadrinhos e Intermidialidade 68

4.1. A intermidialidade como perspectiva metodológica 68

4.2. O prisma de uma arqueologia da intermidialidade 75

4.3. A intermidialidade na leitura do intervalo dos quadrinhos: $\quad 85$ janela para uma arqueologia da intermidialidade

4.4. A montagem nos quadrinhos como remediação da pintura e 93 da literatura

5. Jardim das sinapses: ensaio gráfico biocêntrico

99

6. Conclusão 


\section{Lista de Figuras}

Figura 1 - O progresso de uma prostituta, de William Hogarth 25

Figura 2 - Lenda e vida de São Francisco de Assis. Florença - Itália. 26 Abrigado na British Library.

Figura 3 - Yellow Kid, de Richard F Outcault

Figura 4 - Zoom, filme do roteirista estreante Matt Hansen (com 32 passagem pela editora Marvel canadense), e do produtor Rodrigo Teixeira.

Figura 5 - House of cards, série do Netflix 32

Figura 6 - Brutus Calicot (1846), de Rodolphe Topffer 34

Figura 7 - Desvendando os quadrinhos, de Scott McCloud 35

Figura 8 - 676 Aparições, de Killoffer 36

Figura 9 - Zé Ninguém, de Tito na rua. Grafite em quadrinhos 37

Figura 10 - Zé Ninguém, de Tito na rua. Grafite em quadrinhos 37

Figura 11 - Desvendando os quadrinhos, de Scott McCloud 38

Figura 12 - Desvendando os quadrinhos, de Scott McCloud 38

Figura 13 - Lichtenstein e suas telas 39

Figura 14 - Les Amours de M. Vieux Bois, 1837. A trajetória absurda 40 de M. Vieux Bois em nome do matrimônio

Figura 15 - Desenhando quadrinhos, de Scott McCloud 57

Figura 16 - Desvendando os quadrinhos, de Scott McCloud 58

Figura 17 - Desvendando os quadrinhos, de Scott McCloud $\quad 59$

Figura 18 - Desvendando os quadrinhos, de Scott McCloud 59

Figura 19 - Desvendando os quadrinhos, de Scott McCloud 60

Figura 20 - Desvendando os quadrinhos, de Scott McCloud 61 
Figura 21 - Desvendando os quadrinhos, de Scott McCloud

Figura 22 - Desvendando os quadrinhos, de Scott McCloud 62

Figura 23 - Desvendando os quadrinhos, de Scott McCloud 63

Figura 24 - Desvendando os quadrinhos, de Scott McCloud 64

Figura 25 - The book of job, de William Blake $\quad 80$

Figura 26 - Struwwelpeter, Heinrich Hoffmann 96

Figura 27 - Antônio Dias. Nota sobre morte imprevista 97

Figura 28 - Selvagem, pintura técnica mista, acrílica/ óleo, 80×60cm. 119

Figura 29 - processo de montagem do Jardim das sinapses $\quad 120$

Figura 30 - processo de montagem do Jardim das sinapses $\quad 121$

Figura 31 - processo de montagem do Jardim das sinapses $\quad 121$ 


\section{Introdução}

\section{1}

\section{Apresentação da pesquisa: como tudo começou}

Para saber o que é uma história em quadrinhos é preciso tornar-se leitor desse tipo de obra, e abrir-se à escuta, permitindo-se adentrar nesse vasto e heterogêneo universo. Para perceber a potência dessa linguagem é necessário esquivar-se dos preconceitos do senso comum que considera a leitura de imagens algo menos elaborado que a leitura de textos verbais. Ou, o que é pior, que espera obter da relação entre imagem e texto sentidos necessariamente redundantes, ou meramente complementares. Apesar do lugar central que ocupam as imagens na cultura contemporânea, ainda existe bastante resistência em considerá-las algo mais que um texto codificável, algo cuja potência nos convide à fruição silenciosa e errante.

Admito que, mesmo tendo memórias afetivas dos gibis de infância, apenas tardiamente, na maturidade, consegui livrar-me de preconceitos semelhantes, os quais me faziam considerar as histórias em quadrinhos algo um tanto frívolo, e bem distante da elaboração e profundidade que eu buscava na literatura ou em ensaios teóricos. Encontrei-me já adulta diante de um universo ilimitado de diálogo entre imagens e textos que tematizavam questões complexas, e não apenas isso, mas o faziam adotando estratégias experimentais dispostas a quebrar convenções consolidadas.

Meu interesse nesse preâmbulo é apenas prestar um breve relato sobre o processo que me levou a escolher a montagem nos quadrinhos como recorte temático e também, e não menos importante, como o estudo do tema influenciou as escolhas estéticas que tem acompanhado o processo de escrita da história em quadrinhos que hoje desenvolvo em parceria com Sergio Manon, proeminente artista visual, integrante da iconográfica mostra Como vai você geração 80?, 
recentemente curador e artista da coletiva Máquina do mundo e editor da premiada publicação SANTART (Santa Art Magazine).

Há cerca de sete anos, ao adentrar no campo de roteiros para cinema, tive a oportunidade de me aprofundar nos códigos e convenções que circundam essa escrita tão intimamente comprometida em fazer ver através de um fino equilíbrio entre o dito e o silenciado. Um bom roteiro deve não apenas propiciar à leitura dos demais envolvidos na realização do filme as necessidades de cada cena; deve também cuidar que o encadeamento de cenas propicie a visibilidade do que não é dito. E saber que dentro da malha que tece, as leituras se darão também nos intervalos da obra, sempre. Para dar conta disso, todo aspirante à carreira de roteirista, contudo, aprende, na largada, que sua produção será tanto mais valorizada quanto mais mostrar habilidade em saber $o$ que não mostrar nas imagens e $o$ que não dizer nos diálogos. Esse conjunto de “omissões” bem calculadas vai bem além do compromisso em não adentrar searas que não lhe dizem respeito - como as da produção de arte ou da escolha de planos, por exemplo. Refere-se a um conteúdo que emerge no encadeamento das cenas, e é isso que a costura de um roteirista experiente deve saber revelar no ponto de partida, para que, ao final, a visão do montador arremate a obra. Afinal, como bem expressou a montadora Karen Akerman, "a montagem é a última escrita do roteiro". E, arrisco dizer, nenhum roteirista discordaria que também o roteiro é a primeira edição de montagem. Assim, pelo exercício da escrita de roteiros, em pouco tempo, percebi-me obcecada tanto pelos efeitos que a relação entre imagem e texto podiam criar, quanto pelos vazios e silêncios que os bons roteiros sabiam tão bem preservar. Recentemente, pude vivenciar essas questões - da escrita do roteiro à montagem - a partir de outra mídia: os quadrinhos.

Em 2014, de volta ao ambiente universitário, pude conhecer propostas de histórias em quadrinhos que fugiam completamente ao estereótipo das histórias infantis ou de super-heróis que eu tinha como referência. Tal descoberta incendiou meu interesse por essa linguagem e permitiu-me identificar, no espaço que separa um quadrinho de outro - a chamada "sarjeta" -, o lugar privilegiado para análise dos efeitos e implicações do que intencionalmente se faz ausente dos quadros. Esses intervalos (algumas vezes invisíveis) que fragmentam o olhar, e aqui chamo de 
"sarjetas", adotando a nomenclatura do estudioso em quadrinhos Scott McCloud, nos convoca a unir o que está separado, e a dar sentido no fio condutor da montagem que tanto mais solicita à imaginação quanto mais silenciosa se faz.

Recentemente, a pintura biocêntrica de Sergio Manon fascinou-me à primeira vista: a cultura das plantas, seus comportamentos, a consciência vegetal, temas até então restritos a pesquisas de ponta da neurobiologia, assumem em sua obra expressão estética e política. Ao problematizar o antropocentrismo de nosso olhar, as telas de Manon desafiam-nos a inverter nossa relação de sujeito com o objeto planta. Em seus trabalhos, somos nós - os humanos - os observados. As telas de Sérgio tematizam o mundo das plantas a partir da perspectiva do próprio vegetal, mostrando como sua relação com o ambiente ao redor indica uma forma de existência tão cultural quanto complexa, muito embora invisibilizada por um modo de ver que culturalmente assume o humano como ponto de fuga. As telas de Sérgio Manon resgatam, portanto, nosso olhar de sua cegueira habitual, tematizando a complexidade das relações vegetais.

O tema fascinou-me e motivou-me em leituras, e em meados do ano, Sérgio chamou-me para compor um texto a partir do que eu vinha lendo. Decidimos então, depois de muitas conversas, desenvolvermos juntos uma história em quadrinhos sobre as sinapses vegetais, inserida no campo de pesquisas que o artista desenvolve há alguns anos em suas residências artísticas e que resultará em exposição internacional marcada para meados de 2018. Espero que o projeto de história em quadrinhos Jardim das sinapses: ensaio gráfico biocêntrico, cujo primeiro tratamento faz parte desta dissertação de mestrado, faça jus à força incontestável de suas telas. Importante não deixar de mencionar que a relação de Manon com os quadrinhos remonta aos tempos de suas primeiras exposições já na década 80 , o que certamente tornou sua colaboração neste trabalho ainda mais rica.

Ao longo do processo investigativo teórico, a experiência de confeccionar uma história em quadrinhos deu-me oportunidade singular de projetar sobre meu objeto um olhar côncavo e convexo, ou seja, olhá-lo de fora como pesquisadora da linguagem, e por dentro, a partir do processo de produção. Tal estratégia permitiume estar atenta ao risco de tratar os quadrinhos como um sistema acabado, onde cada detalhe, cada parte, isoladamente, constituísse uma chave de acesso a essa 
linguagem. Ao abordar a estética do fragmento nos quadrinhos, procurei evitar lançar sobre meu objeto um olhar demasiadamente fracionado, o qual, eu sabia, terminaria por extinguir a dimensão fundamental que é o encantamento. Lembreime do poema "A mosca azul", de Machado de Assis, em que um poleá depara-se com um inseto de asas de ouro e tem sua experiência com o sublime. Absorto por instantes pelo êxtase indizível, pela genuína presença do belo que faz sonho e realidade fundirem-se, o homem bruto então não se contenta e quer compreender em pormenores de onde vem tamanha magia. Captura a mosca, obcecado por revelar as razões de seus encantos. Ao fim, a mosca sucumbe e vira uma massa rota e nojenta - algo irreconhecível. Ao perder de vista a dimensão encantadora da mosca azul, o poleá faz lembrar com seu gesto os excessos que cometem os que buscam compreender um objeto em tal grau de minúcia que terminam por sacrificar a experiência estética por inteiro à tirania da interpretação. $\mathrm{O}$ que a prática mostra insistentemente é que certas análises não compensam em resultados o enorme trabalho que requerem.

Foi assim que percebi, entre a vasta bibliografia disponível, o que me serviria nessa pesquisa - e em qual medida. $\mathrm{O}$ que alguns textos me fizeram perceber, às avessas, é que não adianta empenhar esforço imenso em dissecar os quadrinhos, e inventariar suas características, pois estas são instáveis, dinâmicas e flexíveis, sobretudo quando o experimentalismo, rompendo convenções, expande possibilidades e arrisca novos conteúdos, meios e suportes.

\section{2}

\section{Estrutura do trabalho}

Esta dissertação segue o seguinte percurso: no primeiro capítulo, faz uma rápida apresentação dos antecedentes da pesquisa, dos interesses que a motivaram, da conexão de seus temas com a trajetória profissional da pesquisadora, bem como da escolha de apresentar uma dimensão prática do trabalho. Em seguida, procura enumerar os principais objetivos da pesquisa e especificar a metodologia adotada. O segundo capítulo apresenta uma breve historização do percurso das histórias em quadrinhos no Brasil. Pontua-se brevemente nessa seção alguns dados sobre a 
história dos quadrinhos no Brasil, a proibição sofrida em meados do século XX, a presença massiva dos quadrinhos norte-americanos na ocasião em que começou a se constituir um mercado interno, e sua longa trajetória como entretenimento até alcançar a possibilidade de seu reconhecimento artístico.

$\mathrm{Na}$ esteira desse item, realiza-se um sucinto levantamento de estudos sobre esse campo temático retirado da vasta bibliografia disponível, na intenção de dar pequena mostra da sombra de miopia que insiste em se manifestar, em alguma medida, em inúmeras análises dos quadrinhos. Com isso, objetiva-se mostrar que é impossível (e, sobretudo, inútil) situar com precisão a origem dos quadrinhos uma vez que os rastros da presença de uma linguagem sequencial já se insinuavam mesmo antes de existir algo categorizado como "histórias em quadrinhos" e recebido como tal. Procura-se mostrar que a conceituação de "histórias em quadrinho" se faz necessariamente atrelada ao reconhecimento de que sua linguagem foi construída a partir de uma certa constelação histórica, na qual despontam evidentes os rastros de sua relação com outras artes, ou seja, de sua constituição intermidiática.

A presente pesquisa parte do pressuposto de que os quadrinhos, como meio de expressão - embora tenham se consolidado na mídia impressa, entre os séculos XIX e XX, e constituído em torno de si um mercado -, nomeiam, na realidade, práticas de intermidialidade que são parte de uma longa tradição de diálogo entre as artes que remonta ao tópus ut pictura poesis.

No terceiro capítulo, intenciona-se definir a acepção de montagem adotada na pesquisa, esclarecendo que a origem do conceito é anterior ao cinema e referese também a procedimentos usados na pintura e na literatura. Busca-se oferecer uma concepção ampliada de montagem, a partir da qual se pode buscar compreender como operam as relações que conectam diferentes imagens em uma unidade de leitura. A montagem nas artes é tratada nesta pesquisa como expediente que promove associação de imagens heterogêneas e afeta a experiência estética do espectador, habilitando-o a perceber o mundo em perspectiva fragmentada e convocando-o a uma maior participação em sua experiência com o objeto artístico. Argumenta-se que o procedimento de montagem dos quadrinhos que adotam 
estratégias experimentais tende a acentuar a estética da fragmentação, atualizandoa em constantes remediações. O texto Aisthesis, de Jacques Rancière, é usado no intuito de clarear essas questões e contribuir para o entendimento de uma estética do fragmento, e da ideia subjacente de falta, não como deficiência, mas como virtude. Busca-se argumentar que a justaposição dos quadrinhos - aqui identificada como processo de montagem -, sobretudo nos exemplos que evidenciam maior investimento em experiências de linguagem, ao valorizar o fragmento e exigir maior participação do leitor na compreensão de sentidos, criam condições para que os quadrinhos possam ser lidos de forma mais participativa e, por conseguinte, que possam também a ser lidos como arte. Assim sendo, intenciona-se mostrar que a montagem nas histórias em quadrinhos - especialmente naquelas que não tomam para si exclusivamente o objetivo de narrar uma história, com começo meio e fim e associações lógicas entre imagens - convoca o espectador a se relacionar afetiva e criticamente com a obra, sem esperar que as imagens se disponham a uma apreensão passiva, já que é ele, o leitor/espectador, quem cria os sentidos que lhe emergem dos intervalos e constrói seu próprio caminho de fruição.

No quarto capítulo, objetiva-se mostrar em que contexto surgem os estudos de intermidialidade e como dialogam com outros campos do saber interessados em estudos comparativos e interessados também no âmbito cultural de seus objetos. Neste capítulo, objetiva-se também argumentar que os quadrinhos, ao aderirem a procedimentos experimentais, não apenas expandem seu diálogo com outras artes, mas também tornam menos transparentes as relações de intermidialidade constituídas historicamente, e apagadas gradualmente na consolidação de certas convenções da linguagem sequencial. Busca-se, assim, iluminar o caráter intermidiático das histórias em quadrinhos, procurando evidenciar que sua consolidação como linguagem na mídia impressa não configura um ponto de origem, pois é fruto de um longo processo histórico de experimentação e combinação entre artes, entre mídias. Pela mesma razão, sua relação com a literatura é muito anterior ao surgimento do termo "romance gráfico", embora a expressão tenha encontrado grande resistência até a última década do século XX. 
No intuito de mostrar como os quadrinhos podem remediar estratégias da pintura, procura-se apresentar, ainda, neste capítulo, os argumentos de Walter Moser (2006) para a construção de uma arqueologia da intermidialidade, trazendo a noção de remediação para pensar como uma arte retoma, recicla e reapresenta os expedientes de outra, buscando, a um só tempo, adaptá-las à sua materialidade e subverter soluções que já se mostravam consolidadas. A proposta de uma arqueologia das intermidialidade é pensada também a partir do estudo de João Maria Mendes e Arlindo Machado.

No último item do quarto capítulo, resgata-se a noção de leitura do intervalo em João Alexandre Barbosa - como instância que agrega tanto a ficcionalidade e os modos de organização da linguagem quanto aquilo que lhe é exterior, intervalar (que são as dimensões histórica, o cultural e o social) - para pensá-la no contexto da leitura dos quadrinhos. Procura-se argumentar que a percepção da intermidialidade dos quadrinhos se faz no intervalo da leitura, intervalo este que se aplica tanto à leitura da imagem quanto à leitura do texto, aqui neste trabalho pensados de forma mutuamente implicada e indissociável.

O tema da intermidialidade voltará ao fim do trabalho, no quinto capítulo, como parte essencial da escritura do experimento teórico que é parte desta dissertação. Ao partir da série de pinturas Jardim das sinapses, de Sergio Manon, e de um de seus textos de apresentação - o de minha autoria -, buscamos montar um ensaio gráfico - expressão que utilizo para este contexto investigativo no intuito de fazer referência à dimensão ensaística e visual do experimento. Ao dispô-los em uma outra forma de organização, logramos dar visibilidade à remediação da pintura e da literatura pelos quadrinhos, tema deste trabalho.

Uma parte da metodologia deste trabalho, portanto, pretendeu fazer o resgate interdisciplinar de parte da fortuna crítica disponível sobre o tema, no intuito de verificar a plausibilidade dos objetivos de investigação Outra parte igualmente importante da metodologia constitui um experimento teórico na proposição de uma escritura cujas escolhas de montagem foram encorpadas e tornadas conscientes graças à retrospectiva teórica que lhe é concomitante. 
No sexto capítulo, apresentam-se alguns apontamentos sobre o processo de construção e montagem de "Jardins das Sinapses: ensaio gráfico biocêntrico". Objetiva-se mostrar como se deu a prática do exercício de remediação de uma mídia por outra, ou seja, como o texto elaborado para apresentar a série Jardim das sinapses do artista plástico Sérgio Manon em uma de suas exposições foi, posteriormente, reapresentado em outra mídia - os quadrinhos - por um processo de montagem que logrou associar texto e pintura em um projeto de arte sequencial. Por fim, apresenta-se a bibliografia consultada ao longo da pesquisa. 


\section{História em quadrinhos}

\section{1}

\section{Breve panorama da dimensão histórica e cultural dos quadrinhos no Brasil}

O intuito de proceder aqui com uma breve contextualização da história dos quadrinhos no Brasil ampara-se no entendimento de que alguma contextualização cultural desse objeto se faz desejável em uma proposta que, como se pretende argumentar mais adiante, vê no horizonte de uma arqueologia da intermidialidade uma via de acesso abrangente e complexa para os estudos dos quadrinhos.

Vale, contudo, ressalvar que não se tem a pretensão de oferecer um panorama histórico cultural minucioso dos quadrinhos, mas tão somente apontar alguns aspectos ligados à tentativa de sua definição como objeto de estudo e sua institucionalização no país.

No Brasil, as histórias em quadrinho popularizaram-se com o nome de gibi. O que hoje chamamos pelo nome genérico de "histórias em quadrinhos" ganha nomes bem distintos em diversos países - em todos os casos os nomes refletem estreita relação com as questões culturais de cada contexto. Nos EUA, foram chamadas de comics por seu marcado viés humorístico; na França, de bandesdessinées; na Itália de fumetti; na Espanha, tebeos; entre os hispano-americanos, eram conhecidos como historietas, e em Portugal, eram também chamadas de histórias aos quadrinhos.

Em seu artigo Da Gibimania à quadrinhologia, no livro que reúne os pioneiros no estudo em quadrinhos no Brasil, Marcos Marques de Mello ${ }^{1}$ conta que

\footnotetext{
${ }^{1}$ Professor emérito da USP responsável por liderar pesquisa que inventariou, em 1970, o conteúdo de todos os gibis editados no país.
} 
Gibi era o nome da mais famosa revista de HQ do Brasil nos anos de 1940. A palavra significa 'menino preto, negrinho', tal qual o personagem que figurava nas capas da revista. Foi tão grande a sua popularidade, que o nome "gibi" passou a designar qualquer revista do gênero. Originalmente, 'gibi' (nome da história e do personagem) era apresentada em branco e preto e acabou por se impor ao conjunto narrativo para ser veiculado em revista (MELO, 2013).

Não que não houvesse outras publicações do gênero sequencial. Moacy Cirne (CIRNE, 2002) defende que o primeiro quadrinho brasileiro chamou-se As aventuras de Nho Quim, e foi publicado, em 1869, na revista Vida Fluminense. E como mídia específica, somente em 1905, a revista Tico Tico.

Em 1934, o jornal A nação lançou no Rio de Janeiro o chamado Suplemento Juvenil. A ideia nasceu do jornalista Adolfo Aizen e alcançou sucesso em pouco tempo, passando a ser distribuída em todo o país. Pode-se dizer que tal iniciativa marca a entrada massiva de personagens norte-americanos famosos no mercado cultural brasileiro: Flash Gordon, Tarzan, Dick Tracy, Mickey Mouse, e muitos outros.

As histórias em quadrinho chegavam à população das mais diversas formas. Se não havia incentivo, tampouco havia, até certa época, propriamente um movimento de repressão aos quadrinhos. Onde não havia bancas ou livrarias, eles chegavam por encomenda, de ônibus, a pedido de círculos infanto-juvenis de leitura e eram ansiosamente aguardados. Em São Paulo, havia o Sesinho (revista infantil publicada pelo SESI), que continha histórias em quadrinhos, e Gilberto Freyre defendeu os quadrinhos na revista Cruzeiro. Arnon de Mello (da UDN) ganhou as eleições para governador do Estado de Alagoas, baseando sua campanha nas técnicas norte americanas de transformar políticos em super-heróis de história em quadrinhos.

Até meados da década de 1950 houve grande crescimento de publicações. Assim, surgem a EBAL (Editora Brasil América Ltda.), a RGE (Rio Gráfica Editora), a Editora Cruzeiro, a Editora Abril e outras pequenas editoras. Em 1945, foi fundada a Editora Brasil América (EBAL), responsável pela popularização dos 
super-heróis norte-americanos no Brasil, como os personagens das Editoras National DC e Marvel Comics e também pelo lançamento de diversos trabalhos de adaptação de títulos consagrados da literatura em quadrinhos, como foi com Gabriela, cravo e canela, Iracema, O Guarani, além de quadrinhos contando a história do Brasil. Na mesma década, surgiram outras editoras como a Editora Cruzeiro, a Editora Abril e a Rio Gráfica Editora (RGE), caracterizando esse contexto como um período de expansão e consolidação do mercado editorial de quadrinhos no Brasil.

Nos anos de 1950, contudo, o hábito de ler histórias em quadrinhos começou a suscitar a ira de alguns grupos, chegando a tramitar no Congresso Nacional uma lei de proibição dos gibis. A história de repressão que se seguiu a partir de 1950 abarca diferentes etapas que vão desde a rejeição elitista de parcela da sociedade até verdadeira perseguição de Estado, nos anos 60, incluindo queima de arquivos e livros nos tempos da ditadura.

Melo refere-se a uma verdadeira "quadrinhofobia" para caracterizar a perseguição sofrida no Brasil pelo gênero sequencial. O livro de Gonçalo Junior reconstitui essa história e conta como Victor Civita, da Abril, conseguiu se estabelecer no mercado:

Quando a Abril entrou no mercado, aqueles eram tempos difíceis para quem lia ou editava histórias em quadrinhos. Vítimas de preconceito por parte dos padres, educadores, donas de casa e políticos, os gibis foram parte de uma intensa campanha de difamação entre as décadas de 1940 e 1960. Na imprensa eram temas frequentes de denúncias: provocavam preguiça mental aos leitores, estimulavam a prostituição e o consumo de pornografia, induziam menores ao crime e desnacionalizavam as crianças (JUNIOR, 2004, p. 92-93).

A reação à repressão e ao banimento dos quadrinhos atuava em duas frentes distintas: uma que defendia o valor estético dos quadrinhos em geral e outra que pretendia defender os quadrinhos nacionais diante da ofensiva dos super-heróis importados. De fato, leitores, colecionadores e amadores a essa altura já haviam assimilado as figuras lendárias ianques: Mandrake, Tarzan, Flash Gordon, Roy Rogers e outros. Uma das obras em quadrinho de maior impacto no mercado brasileiro - e não apenas neste mas na América Latina inteira - foi aquela intitulada 
Para ler o Pato Donald. O livro propunha ensinar o leitor a perder sua inocência, e ter atenção aos mecanismos imperialistas dos gibis. Trazia um prólogo sob o título singelo de "Prólogo para pato-logos".

Os temas ligados a super-heróis predominaram na indústria dos quadrinhos até fins da década de 80 no mercado brasileiro sob forte influência norte-americana. E conviveram com a brilhante presença de Mafalda, Calvin e Asterix, entre outros. Na transição para a década de 90, a expressão graphic novel começou a ser usada no Brasil, e algumas histórias de super-heróis chegaram a publicar também nesse formato, procurando se reinventar e ampliar seu público leitor. Sobre a perspectiva do mercado acerca dessa nova nomenclatura, diz Paulo Ramos:

Percebe-se, nessa rápida trajetória, que a expressão nos Estados Unidos esteve cunhada numa preocupação de atingir um público leitor mais maduro, com temas que versassem ou não sobre super-heróis, mas que apresentassem uma qualidade editorial mais trabalhada. Não se tratava de comics, mas de uma outra forma de quadrinhos. Comercialmente, significava atingir outra fatia de mercado, o adulto, ainda pouca explorada. (RAMOS e FIGUEIRA, 2011, p. 4)

\section{2}

\section{Quadrinhos e seus campos de estudo}

Há quase cinco décadas os quadrinhos vem sendo objeto de diferentes campos do conhecimento no meio acadêmico. Já no ano de 1972, dois marcos institucionais importantes no campo de pesquisa dos quadrinhos merecem destaque: a criação da disciplina "História em Quadrinhos" e a criação do Núcleo de Pesquisas em Histórias em Quadrinho, ambas na Escola de Comunicação da USP. Para além dessas iniciativas, esse campo temático vem sendo alvo de interesses de disciplinas diversas. O mapeamento detalhado desses esforços excede os objetivos deste trabalho, sendo suficiente, para o que se pretende aqui, apontar brevemente alguns aspectos que têm sido valorizados na tentativa de encontrar uma definição para os quadrinhos e como, em boa medida, essa atividade tem perdido, em sua tentativa de entender e demarcar fronteiras entre quadrinhos e outras formas de 
expressão, o que enriquece verdadeiramente o entendimento dessa linguagem que é a rica rede de relações que se estabelecem entre os quadrinhos e outras artes.

Algumas abordagens procuram tomá-los como ferramenta pedagógica, esvaziando de certa forma o potencial artístico dos quadrinhos na valorização excessiva de uma intenção didática; outras discutem seu estatuto de arte, resgatando discussões que, ao menos nas artes plásticas, pareciam já encaminhadas depois do urinol de Duchamp, das vanguardas das primeiras décadas do século XX e da Pop Art. Há também as que propõem um olhar histórico, na intenção de definir o autor do primeiro quadrinho e a obra que teria inaugurado uma linguagem autônoma. E há, ainda, as que procuram percebê-los sob a ótica de uma intermidialidade comparativista, traçando paralelos de semelhanças e diferenças em relação a outras linguagens, sem, contudo, valorizar propriamente as potencialidades contidas nas diferenças, mas, antes, o contrário, dispondo essas diferenças como índice de limitação de uma mídia em relação a outra. De certa forma, parecem propor que certas características midiáticas - por exemplo, o movimento e o naturalismo da representação - sejam, por premissa, assumidos como índices de superioridade de uma mídia em relação a outra.

Feitas essas considerações gerais acerca de algumas tendências de análises que assumem os quadrinhos como objeto de estudo, o primeiro aspecto que vale ressalvar é que, em alguma medida, muitas dessas análises mostram não fazer distinção clara entre as revistas em quadrinhos e suas questões de mercado e as diversas formas de expressão dos quadrinhos. Grande parte delas parece, ainda, negligenciar as questões de intermidialidade que são constitutivas dessa linguagem, e elegem meras convenções como se fossem elementos que conferissem uma especificidade capaz de pontuar o "marco zero" dos quadrinhos como linguagem autônoma.

Nesse momento, parece oportuno, mesmo muito resumidamente, especificar algumas das principais abordagens e definições dos teóricos mais importantes no campo de estudo dos quadrinhos.

Sonia Bibe-Luyten (1993) define as HQ a partir de um único elemento: o balão, ou seja, o texto contido por uma linha de contorno variado, e que aponta em sua 
extremidade para o personagem que exprime o pensamento ou a fala. Esta definição considera essencialmente as HQ como forma particular de junção de imagens e linguagem escrita. Como argumento, lembra que na Itália as HQ assumiram o nome de fumetti, ou seja, fumacinhas, significando balões. Os balões, segundo os defensores desta hipótese, caracterizariam as HQ por instituírem uma relação orgânica entre imagem e texto, diferente das obras nas quais o texto vem abaixo da imagem, servindo esta muitas vezes apenas como ilustração do primeiro. Com o surgimento do balão, os personagens passam a poder expressar-se com suas próprias palavras. A partir desta definição, a autora coloca como marco que considera como inicial para o surgimento das HQ o aparecimento, em 1894, do Yellow Kid, criação de Richard F. Outcault para o New York World, jornal sensacionalista de propriedade de Joseph Pulitzer. Trazia este nome, o Moleque Amarelo, por se destinar inicialmente a testar a cor amarela, usada pela primeira vez na impressão de jornais. O surgimento desta tira é visto como marco pela autora por ter sido aí que pela primeira vez o texto falado foi colocado dentro da imagem, e não exterior à mesma (em geral abaixo ou acima dela). (...) Esta definição, portanto, considera HQ tudo aquilo que contiver balões, e exclui toda e qualquer obra que não os tenha. (GORENDER, 2008, s/n)

Há, porém, boas razões para discordar de Sonia Luyten. A primeira é a existência de obras como as de William Hogarth que, ao conceber em conjunto gravuras e pinturas, já em 1831, trazem na montagem o parentesco inegável com os quadrinhos, sem contudo recorrerem ao discurso direto contido em balões. Conhecido no Brasil como "O progresso de uma prostituta", a obra do artista inglês mostra a história da jovem M. Hackabout que chega em Londres e é aliciada por uma mulher idosa que elogia sua beleza e sugere uma função rentável a essa virtude: a aquisição dela por um cavalheiro. A ausência de texto tampouco compromete a leitura, embora, sim, demande do leitor, maior participação na construção de um fio narrativo. 


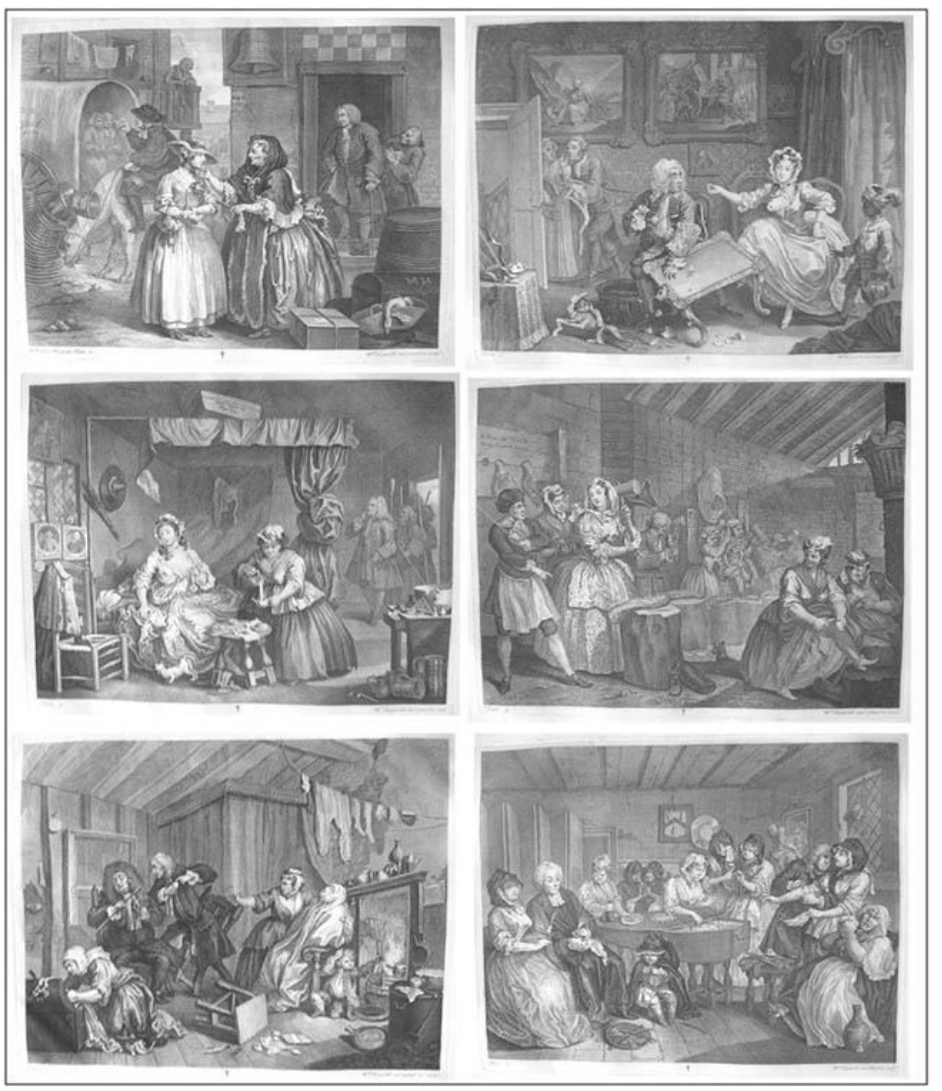

Figura 1: "O progresso de uma prostituta", de William Hoggarth (1835). S/n.

A segunda razão, ainda mais contundente, é que o uso do balão é bem mais antigo que a invenção da imprensa. Em iluminuras medievais, por exemplo - aponta ainda Miriam Gorender (2008) -, pode-se ver fitas com frases que apontam para os personagens, com função semelhante aos balões. É o que ilustra a imagem abaixo: 


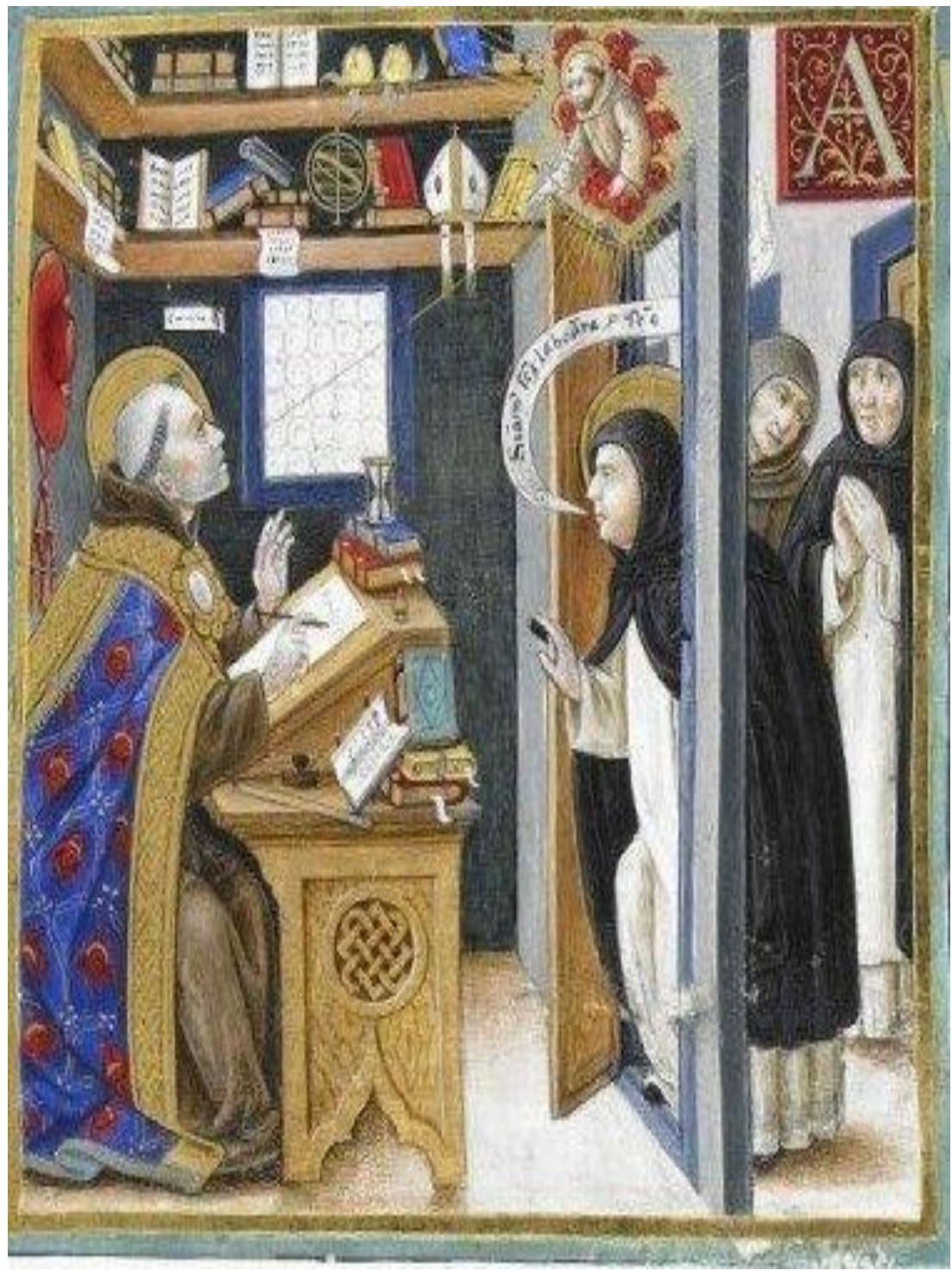

Figura 2 - Lenda e vida de São Francisco de Assis. Florença - Itália. Abrigado na British Library.

A ascensão do Yellow Kid, em 1894, é interessante mencionar, foi parte de uma estratégia de aumento de venda de grandes jornais e esteve ligada a uma forte disputa de mercado entre dois grandes magnatas da imprensa norte-americana William Randolph Hearst e Joseph Pulitzer, ambos de Nova York. Vem dessa época a expressão Yellow Press, como sinônimo de sensacionalismo, já desde então relacionados ao universo dos quadrinhos. 


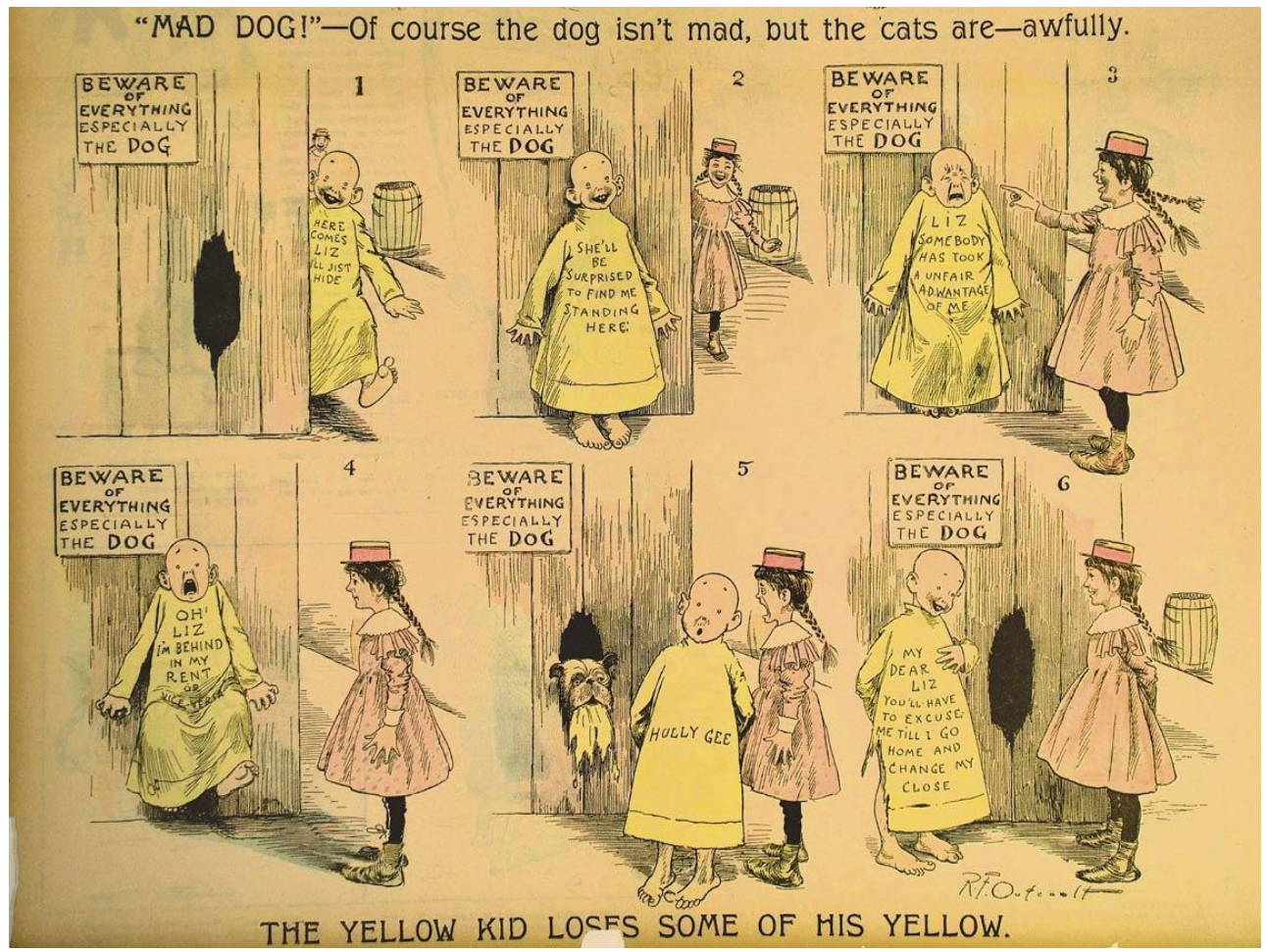

Figura 3 - Yellow Kid, de Richard F Outcault (1895). S/n.

É claro, contudo, que as formas e as linhas dos balões, ao passarem a ser amplamente empregados em revistas, começaram a ser identificados como um recurso específico dos quadrinhos. O convencionalismo dos balões produziu expressiva diversidade de formatos. O crítico de cinema Robert Benayoun chegou a identificar 72 tipos diferentes de balões para falas e onomatopeias.

Outro estudioso dos quadrinhos, Moacy Cirne apresenta a seguinte definição:

Os quadrinhos são uma narrativa gráfico-visual, com suas particularidades próprias, a partir do agenciamento de, no mínimo, duas imagens desenhadas que se relacionam. Entre as imagens, um corte, que chamaremos de corte gráfico - de certo modo, o lugar que marca o espaço do impulso narrativo. Esse corte tanto será espacial quanto temporal, aqui, gerando as elipses: um tempo a ser preenchido, muitas vezes, pela imaginação do leitor. (CIRNE, 2002, pág.14)

Cirne chame atenção para um aspecto fundamental nos quadrinhos: a participação da imaginação do leitor, especialmente requerida pelo corte e pelo agenciamento de imagens. No entanto, ao definir esse corte como um corte gráfico 
e ao incluir também na definição que são necessárias pelo menos duas imagens, Cirne deixa de fora tanto os quadrinhos que conseguem abolir a visualidade gráfica da sarjeta (veremos à frente um exemplo disso em 676 aparições de Killoffer) quanto os cartoons que se constituem de uma única imagem. Visão compartilhada também por McCloud, como se problematizará um pouco mais adiante.

Além disso, a visão de Cirne de que os quadrinhos são fundamentalmente um fenômeno da cultura de massa - uma consequência do advento e aprimoramento da imprensa, e principalmente dos jornais americanos ou europeus de grande tiragem -, deve igualmente ser problematizada já que constitui certa simplificação que obscurece as camadas arqueológicas constitutivas dessa linguagem, que permitiram sua exploração pelos meios de comunicação em massa.

A análise semiótica de Thierry Groensteen, por seu turno, propõe analisar os fundamentos da linguagem dos quadrinhos a partir da descrição minuciosa de suas unidades constitutivas, explicando cada um de seus mecanismos de produção de sentido. Apresenta conceitos extraídos daquilo que nomeia de "neosemiótica", como "espaçotopia" e "artrologia", por exemplo. São detalhamentos que, se não chegam às "pupilas do personagem" - como ele mesmo ironiza ao referir-se aos exageros de minúcias da semiótica tradicional -, excedem-se igualmente ao pretender descrever à exaustão os recursos que elenca como mais importantes. Além disso, Groensteen parece olhar para os quadrinhos exclusivamente a partir do modo narrativo clássico:

"O plano do quadro deveria ser considerado como principal. (...) Posso traduzir ou exprimir o que vejo dentro do quadro (o que daquilo que é mostrado) em termos linguísticos (...). O segundo plano é o do sintagma, limitado, quando ocorre, à tríade composta pelo quadro que está sendo lido, o que o precede e o que lhe é posterior. Nesse nível, minha leitura do quadro já é forçosamente distinta, informada antes e depois por outros conteúdos, com os quais construí (ou conferi), tendo a base de um postulado de coerência narrativa, as relações semânticas." (GROENSTEEN, 2015, p. 118)

Groensteen defende a primazia do visual no discurso do quadrinho, mas percebe a imagem a partir do enunciável para reduzi-la à sucessão de um descritível e um interpretável. 
O Brasil foi um dos primeiros países a investir na tematização acadêmica das histórias em quadrinhos, como assinala Robert Weiner (2017), no capítulo "The educators" do livro The secret origins of comics studies ${ }^{2}$. Os primeiros estudos dentro da universidade datam de 1967, e devem-se ao pioneirismo de Waldomiro Vergueiro, um dos criadores do Observatório de Histórias em quadrinhos, grupo de pesquisa da Escola de Comunicações e Artes da USP, para quem não existe propriamente uma teoria dos quadrinhos, mas, sim, perspectivas de análise vindas de diferentes campos do conhecimento.

“Os quadrinhos não possuem uma teoria própria. Ou seja, não existe uma base
teórica acadêmica voltada apenas para os quadrinhos, por tratar-se de uma área de
pesquisa que esteve muito tempo fora do ambiente acadêmico. Por isso, para
realizarem seus estudos, os pesquisadores usam elementos de outros campos, como
da Linguística, da Semiótica, da História, da Comunicação, das Letras, da Psicologia,
da Educação, da História, da Geografia, entre outros". (VERGUEIRO, 2013, p. 53)

Por muito tempo, os quadrinhos foram vistos, equivocadamente, como mera linguagem de entretenimento, cujos recursos não permitiriam um resultado à altura do que poderia ser considerado artístico. A desvalorização dos quadrinhos explica em grande medida uma quantidade expressiva de estudos convencionais e repetitivos em torno deste campo. Mas, se por um lado, o contexto de que fala Vergueiro nos obriga a reconhecer a situação de desprestígio de que a falta de uma teoria própria pode ser efeito, por outro, não há como ignorar um desdobramento colateralmente positivo dessa marginalidade: a ausência de uma teoria específica não privou os quadrinhos de se tornarem objeto de perspectivas muito distintas de análise, não necessariamente uma melhor que a outra, mas, sim, complementares.

As críticas brevemente indicadas nessa seção, é bom ressaltar, não pretendem, de modo algum, negar as extensas contribuições dos autores citados, mas tão somente explicitar certa insistência em definir especificidades, em

\footnotetext{
${ }^{2}$ Organizado por Mathew J Smith e Randy Duncam em 2017, pela editora Routlege e disponível em:

$<$ https://books.google.com.br/books?id=qno2DwAAQBAJ\&pg=PT67\&lpg=PT67\&dq=fi rst+academic+work+about+comics\&source=bl\&ots=ui0c-

A_rub\&sig=OHqB85F5vVtHM>
} 
detrimento daquilo se buscará iluminar aqui, que é a intermidialidade constitutiva dos quadrinhos.

Há pesquisas no âmbito dos estudos de intermidialidade que, ao buscarem compreender as relações de intermidialidade, tendem a se fixar predominantemente no objeto, negligenciando, em boa medida, a relação, o fluxo e movimento dessas apropriações, recriações e adaptações. O que daí resulta, muitas vezes, é um esforço analítico rico e minucioso mas que perde a profundidade da cena em favor de um primeiro plano em alta definição. Metáforas à parte, uma vasta e detalhada terminologia procura dar conta de comparar as artes e dispô-las em lados separados, reconhecendo (ou asfaltando) especificidades de acordo com a materialidade dos objetos em questão. Estabelecem linhas divisórias entre quadrinhos e literatura ou quadrinhos e pintura, ignorando o diálogo entre eles e enfatizando diferenças técnicas entre as mídias usadas. Mostram, nesses casos, sobretudo motivação normativa, esforçam-se por fixar limites e possibilidades para as artes a partir de um estreito entendimento das possibilidades de expansão inerente à criação artística. O que efetivamente resulta desses esforços é uma sucessão de descrições das capacidades de uma mídia que pouco faz avançar o entendimento sobre a relação - propriamente dita - de intermidialidade dos quadrinhos com outras artes:

Filmes e HQs são mídias que contam histórias através de séries de imagens: o espectador vê pessoas atuando - enquanto em um romance as ações devem ser descritas verbalmente. Mostrar é narrar no cinema e nas HQs. Porém, enquanto as narrativas fílmicas clássicas situam o espectador no centro do espaço diegético os quadrinhos por outro lado estão firmados em uma tradição parodística (CHRISTIANSEN, 2000, p.118). Desde o século dezenove, a maioria dos quadrinhos tem como principal característica o uso de deformações geralmente caricaturais, em diversos graus. Ao mesmo modo a disputa entre textos e figuras e o fato que as figuras serem desenhadas lembram o leitor de sua condição artificial. Além disso, filmes e HQs diferem significativamente não apenas na maneira como são vivenciadas e recebidas pelo público mas também em sua forma material. Isso introduz várias questões problemáticas para a adaptação de uma HQ para um filme live action. (...) Mas, além disso, há também o problema da primazia: normalmente, as pessoas preferem a primeira versão que encontram de uma história.(LEFÈVRE, 2012, p. 191).

Pascal Lefèvre parece misturar em um mesmo escopo de análise diferentes dimensões implicadas em uma mídia, - como sua materialidade e as condições de recepção, por exemplo. Além disso, forja limites às artes, imputando-os às mídias, 
na intenção de formatar uma teoria da intermidialidade capaz de definir as fronteiras intransponíveis de cada arte. Se, mesmo Lessing, apesar de seu intuito normativo de distinção entre as artes, foi capaz de admitir, no século 18, as zonas cinzentas das artes, aquelas que fogem ao preto e branco das ideias normativas, e realizam algo prodigioso, há de se perguntar por que Lefèvre, no século 21, parece ainda querer negar os inúmeros experimentos de linguagem que mostram não serem intransponíveis as questões que ele relaciona com a materialidade, mas muitas vezes meramente convencionais, fruto de escolhas que se consolidaram, ou mesmo momentâneas, relacionadas ao aparato tecnológico disponível de uma época. Mais adiante, neste trabalho, ao trazer as questões trabalhadas por Arlindo Machado sobre os usos não submissos do aparato tecnológico pelo artista, pretende-se ainda apontar criticamente como uma visão meramente comparativa das mídias por vezes parece reduzir a relação entre elas a uma lista de especificidades determinadas pelo aparato tecnológico.

Não é difícil encontrar exemplos que contradigam a rigidez que a lista de semelhanças e diferenças de Lefèvre sugere. O filme Zoom, de Pedro Morelli por exemplo, transpõe para a tela do cinema alguns dos recursos dos quadrinhos, como por exemplo, a imagem gráfica e estática, a sarjeta e o requadro.

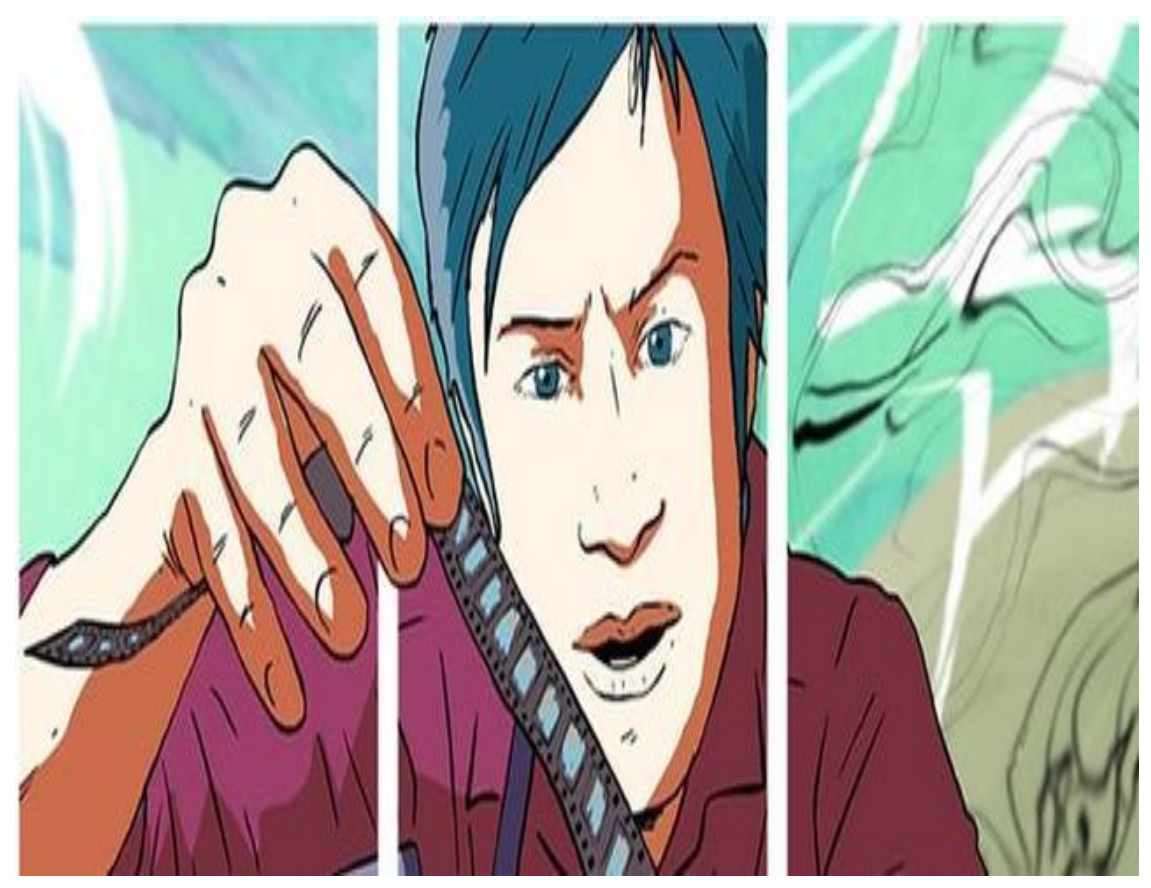


Figura 4 - Filme Zoom, do roteirista estreante Matt Hansen (com passagem pela editora Marvel canadense), e do produtor Rodrigo Teixeira.

Outro bom exemplo que chama atenção para a plasticidade das mídias, é o que nos mostra a cena abaixo:

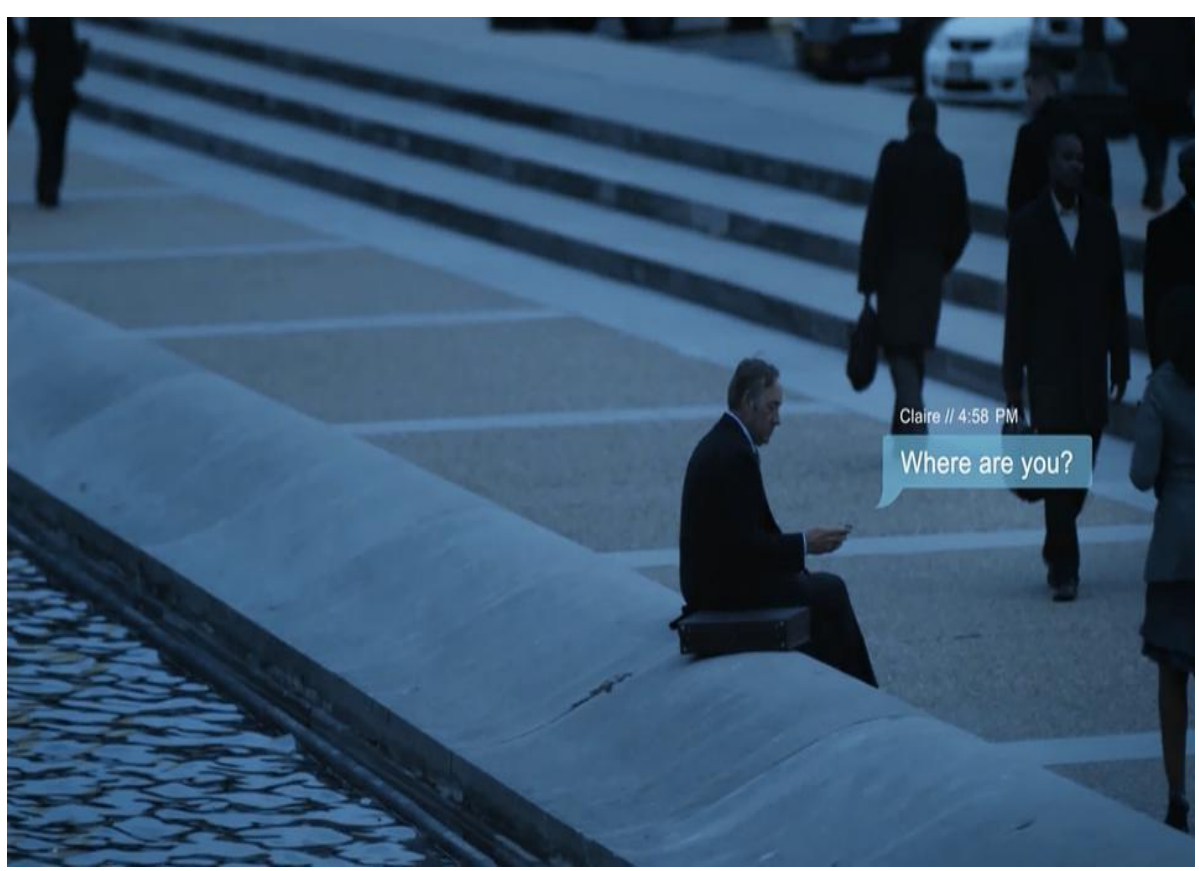

Figura 5 House of cards, série do Netflix (2016)

Um filme pode justapor um texto gráfico sobre as imagens, na forma de um elemento não-diegético, ou seja, fora da ação ficcional do filme. Na cena acima, um expediente dos quadrinhos é reapresentado em outra mídia, as séries de TV. O processo de reapresentação de uma mídia por outra cria uma zona de nuance que as análises muito preocupadas em descrever os limites e diferenças entre mídias não conseguem explicar e por isso mesmo esforçam-se por ignorar.

Parece bastante contestável, além disso, que o critério de "primazia" conferido pelo público à obra, sugerido por Lefèvre, tenha algo a ver com discussões sobre intermidialidade que relacionam os quadrinhos e o cinema. Talvez sua menção por Lefèvre queira apenas ressaltar que, na perspectiva comparativista, a expectativa do público assume uma forma como modelo a ser copiado. Ora, a reapresentação dos procedimentos de uma mídia por outra inevitavelmente se dará a partir de soluções condicionadas à materialidade e à linguagem. 
Vale a pena, também, refletir sobre o que diz Lefèvre acerca da condição artificial dos quadrinhos. Para o autor, essa condição artificial seria mantida pelo traço icônico do desenho ou com a justaposição de texto e imagem. Mas se o desenho fosse, realmente, condição de artificialidade, a sua substituição por fotografias (como são as fotonovelas, por exemplo) suprimiria parte dessa "artificialidade"? Ou mesmo a ausência de texto justaposto, deixando a história a cargo apenas da imagem, atingiria também o mesmo efeito de suprimir a artificialidade? Parece mais razoável atribuir essa suposta "artificialidade" possivelmente melhor identificada como um traço de opacidade da mídia, ao qual se fará referência mais adiante - à representação fragmentada do tempo, não contínua, que se torna visível na presença de requadros que emolduram quadros fixos ou à presença da sarjeta entre eles. Além disso, a relação entre imagem e texto não parece ser a de disputa como caracteriza o autor.

É razoável admitir que, de acordo com o suporte, a história inteira ganhe nova montagem e novas referências visuais, mas estas não apontam para limites ou comparações - como parece se esforçar por demonstrar Lefèvre -, e, sim, para condições diferentes de experimentação e novas manifestações de intermidialidade.

Em nome da especificidade, há autores que consideram possível, e alguma medida útil à normatização que buscam construir, precisar a origem dos quadrinhos, e também, a reboque, seu primeiro autor. Por trás de tal motivação, está o desejo de arbitrar que elementos consolidaram o que hoje chamamos de revista em quadrinhos e apagar as camadas intermidiáticas que permitiram que isso acontecesse.

Entre os mais citados autores considerados "criadores" dos quadrinhos, estão o ítalo-brasileiro Ângelo Agostini, com Nho Quim (1867); o inglês Gilbert Dalziel, com Ally Sloper's Half Holiday (1895); o alemão Wilhelm Busch, com Max e Moritz (1865); e o norte americano Richard Outcault, com Yellow Kid (1884). O suíço Rodolphe Topffer é também bastante citado sobretudo por ter sido um dos primeiros a experimentar uma existência codependente entre imagem e texto. 


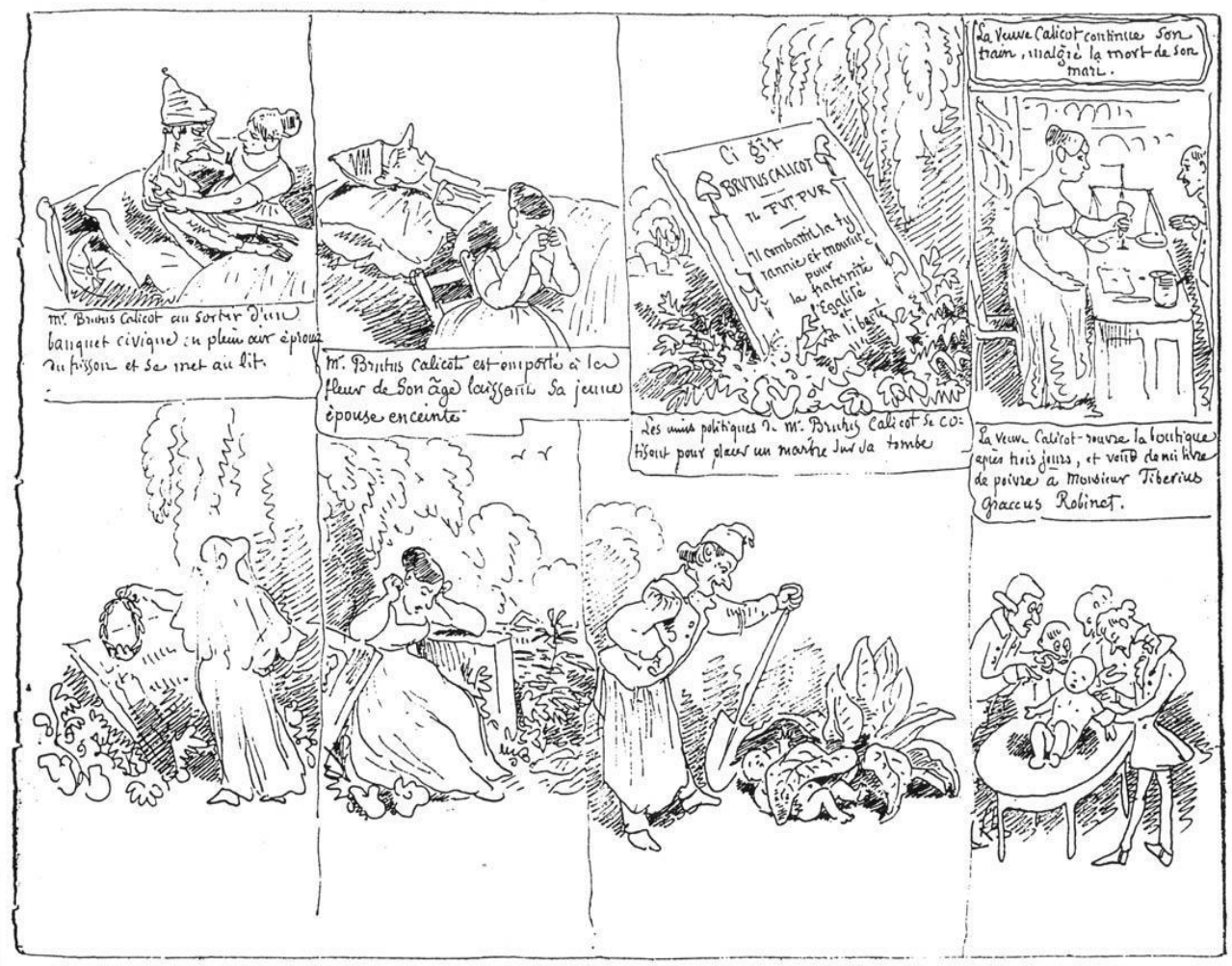

Figura 6 - Brutus Calicot (1846), de Rodolphe Topffer.

Scott McCloud, um dos mais referenciados pesquisadores dos quadrinhos, os define assim:

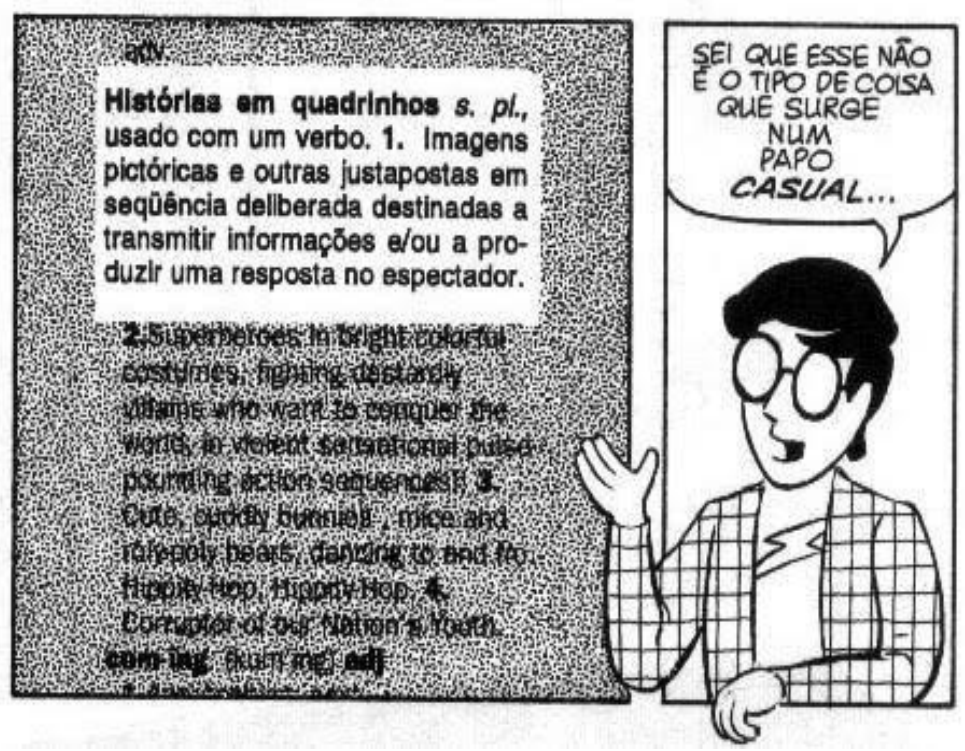

Figura 7: Desvendando os quadrinhos, de Scott McCloud. p. 9 
A definição acima oferece um razoável mínimo-comum, que, apropriadamente, resiste em fazer referências restritivas a "estilo, qualidade ou assunto", preservando-se igualmente neutra em relação à mídia utilizada. Vale a pena lembrar, entretanto, que a justaposição nem sempre é pontuada por sarjetas. Mesmo na ausência delas, ou seja, do intervalo entre quadros, este intervalo está presente. Tudo o que não se apresenta visualmente é, por outro lado, imaginado por um público leitor que já se habituou às convenções da leitura sequencial de imagens, inclusive às sarjetas, e coopera, acrescentando sentidos e imagens ausentes. A figura abaixo (à direita) permite perceber que a sequencialidade em 676 aparições de Killoffer recria a sarjeta ao apagá-la em sua representação gráfica e espacial no quadrinho. Além disso, o quadrinho Killoffer mostra, sim, imagens justapostas, mas não necessariamente sequenciadas, já que nenhuma ordem de leitura está de antemão sugerida. A sequencialidade pode ser imaginada nesta cena de Killoffer, em várias direções, e até um sentido de simultaneidade é possível de ser depreendido, mas dependerá sobretudo do olhar do leitor, sem ser, efetivamente, um dado gráfico visível.

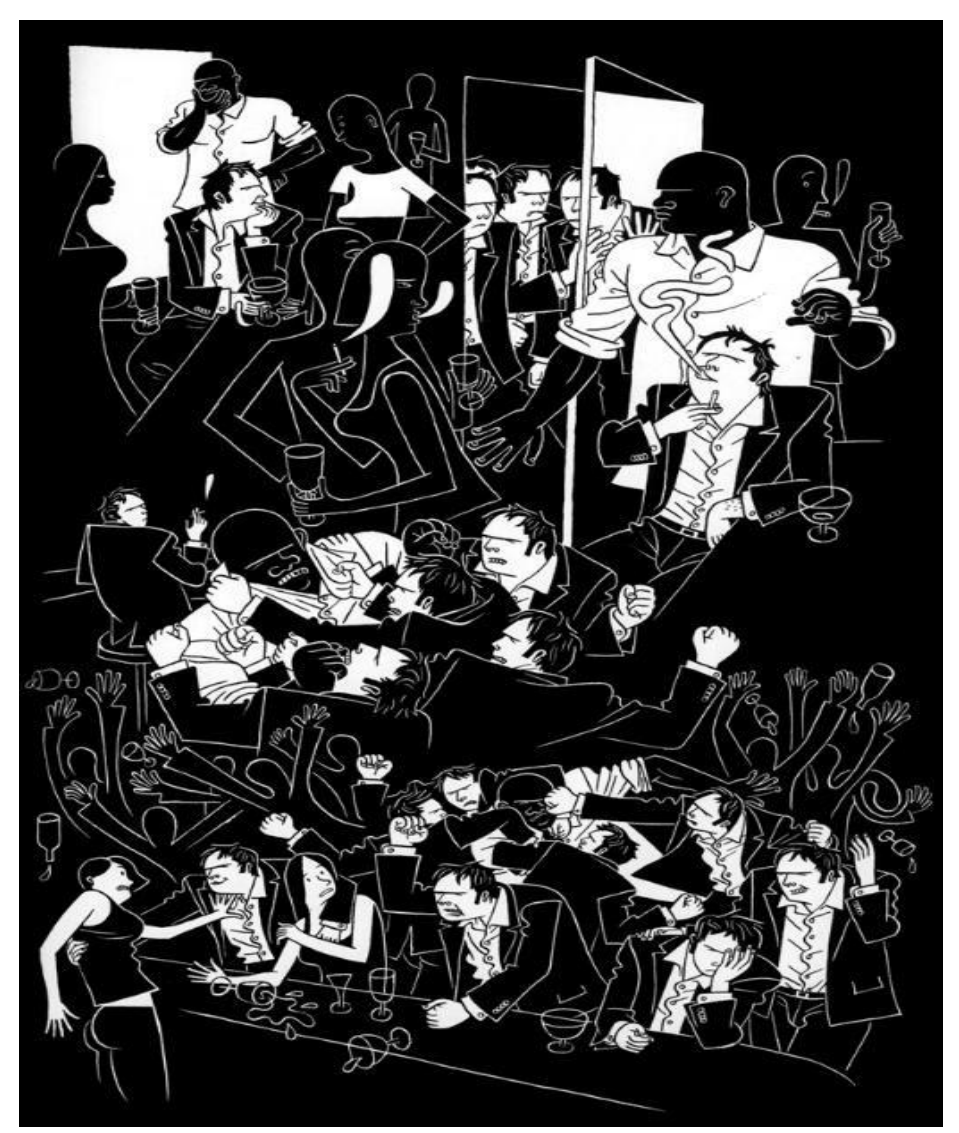


Figura 8. 676 Aparições de Killoffer. S/n

Abrindo mão da noção de sequencialidade, reforça-se a noção de que tanto a imagem quanto a palavra encontram formas de fazer imaginar aquilo que respectivamente não está nem visível nem dito.

$\mathrm{O}$ que se gostaria de sublinhar aqui é que os quadrinhos permanecem reconhecíveis como linguagem mesmo quando subtraem-se um de seus expedientes mais convencionais, aqueles que se misturam com as próprias condições de possibilidade dos quadrinhos.

O exemplo de Zé Ninguém constitui outro exemplo a partir do qual se pode observar a mesma questão. Existem espalhados pela cidade do Rio de Janeiro muitas imagens únicas de Zé Ninguém. Ao trafegar pela cidade, as pessoas as percebem e as editam mentalmente de acordo com seu trajeto. Não existe, neste caso, uma sequência prévia. Não obstante, a obra foi editada em livro, encontrando nessa realização uma ordem específica proposta pela editora.

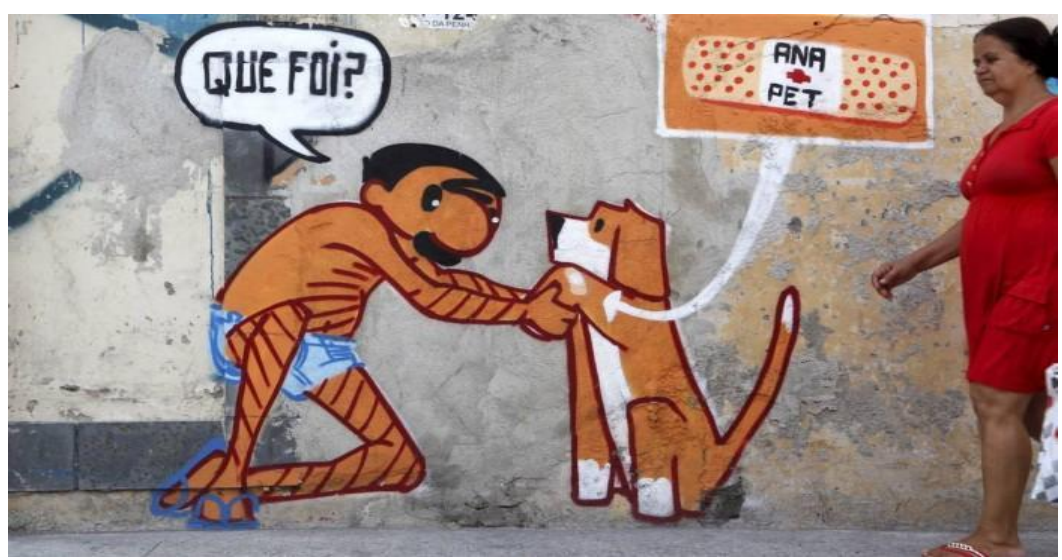

Figura 9 - Zé Ninguém, de Tito na rua. s/n 


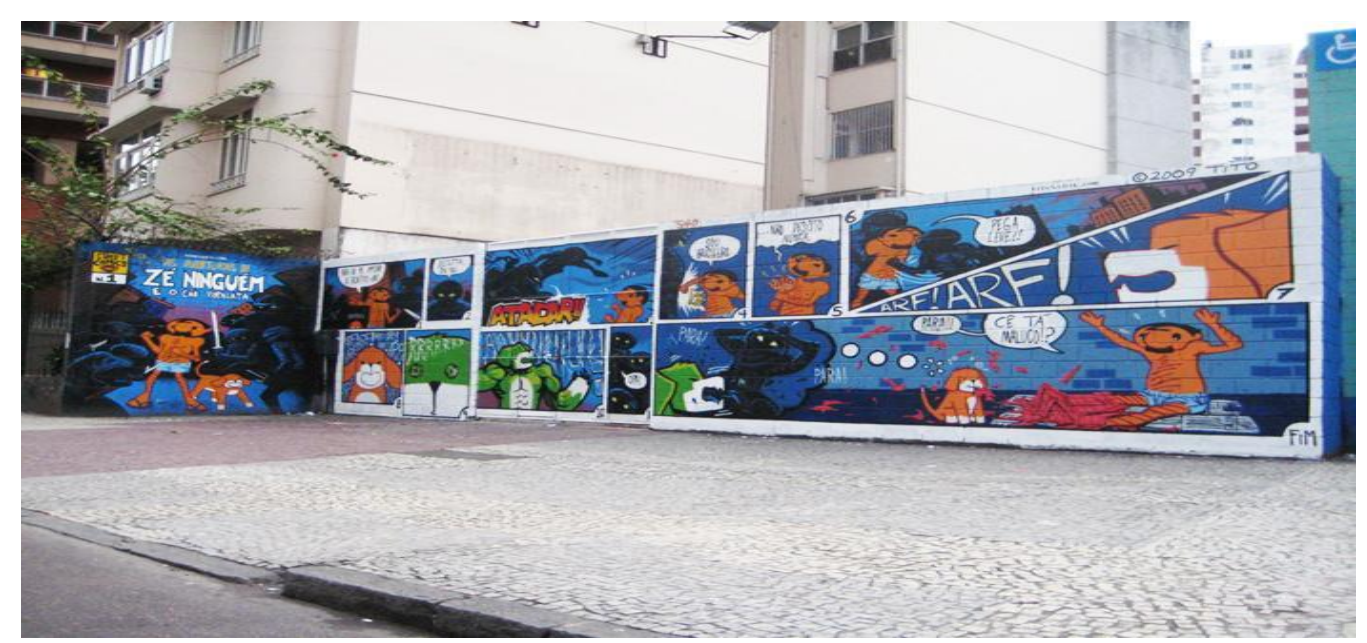

Figura 10 - Zé Ninguém, de Tito na rua. s/n

Afinal, as zonas cinzentas sempre desafiam as definições em qualquer tentativa de fixar elementos sine qua non. As diversas experiências de linguagem realizadas no campo dos quadrinhos mostram suas falhas, suas fissuras, e é justamente na manutenção dessas fissuras que as artes dialogam e mantém-se vivas, em permanente transformação.
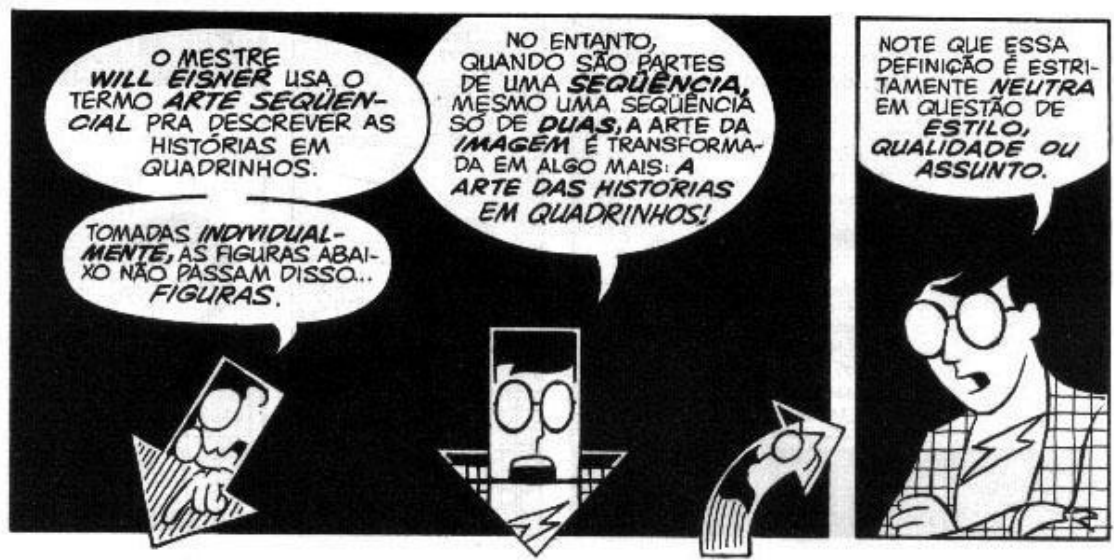

Figura 11 - Desvendando os quadrinhos, de Scott McCloud; p.5

A definição de McCloud, no entanto, traz por outro lado um aspecto interessante: ao se referir a "imagens pictóricas e outras justapostas", parece razoável supor que McCloud esteja se referindo às palavras também como imagens a ser codificadas e, portanto, palavras como mediadoras de sentido, e, em última instância, também elas, uma mídia. 
Uma última ressalva, contudo, merece ser feita em relação àquilo que a definição de McCloud exclui. Ao afirmar, categoricamente, que os cartoons não são histórias em quadrinhos por serem um quadro único e não comporem sequência, McCloud ergue uma barreira frágil entre ambos e uma limitação de pouca serventia à definição.
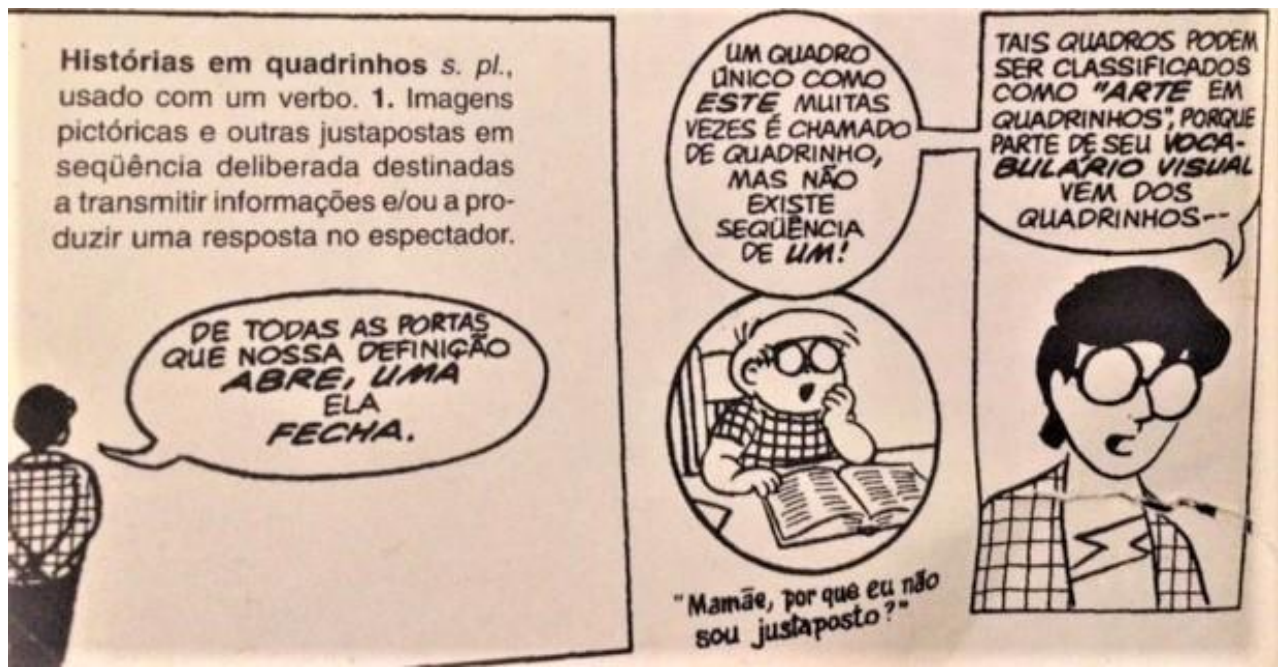

Figura 12 - Desvendando os quadrinhos, de Scott McCloud; p.20.

Entre os cartoons e os quadrinhos há certamente mais em comum que em discordância, como é fácil perceber a partir de elementos como a justaposição de texto e imagem, os desenhos e a possibilidade de transmitir espacialmente a passagem de tempo. Além disso, aceitar a restrição de McCloud em relação aos cartoons, exigiria, pelas mesmas razões, a abrir mão da ideia de intermidialidade que permeia os quadrinhos, e que os liga a realizações da pintura e da literatura.

Por essa mesma lógica de argumento, as telas de Roy Liechtenstein seriam uma apropriação dos cartoons, e não dos quadrinhos, o que seria uma distinção muito pouco relevante para pensar a obra do artista e sua proposta. 


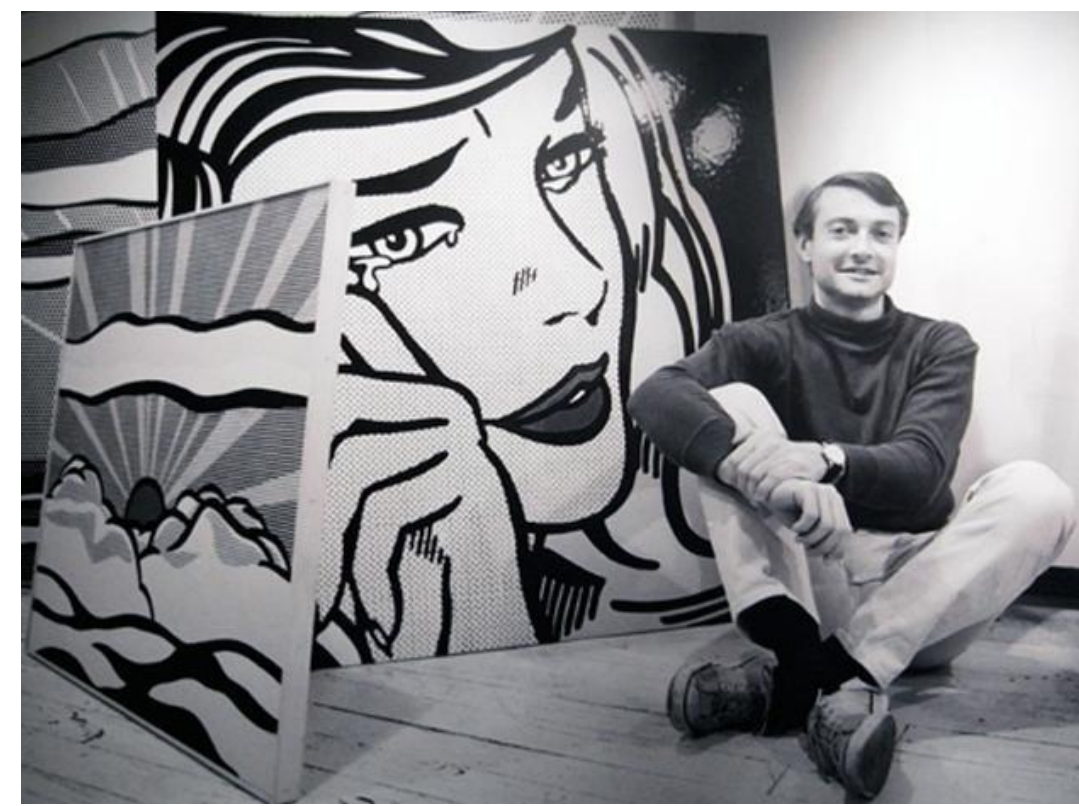

Figura 13 - Lichtenstein (1923-1997) e suas telas. S/n.

McCloud afirma que Rodolphe Topffer deveria ser considerado "o pai dos quadrinhos modernos" (MCCLOUD, 2004, p.17) ainda que o próprio Topffer não tivesse consciência de estar criando uma linguagem nova, misturando escrita e imagem. Segundo o autor, em 1850, Topffer foi o primeiro que empregou caricatura e requadros, apresentando relação interdependente de palavras e figuras. McCloud toma o cuidado de não conferir uma paternidade genérica a Topffer, e caracterizar como "moderno" o gesto de conceber certas convenções que viriam, definitivamente, a fazer parte do universo dos quadrinhos. 


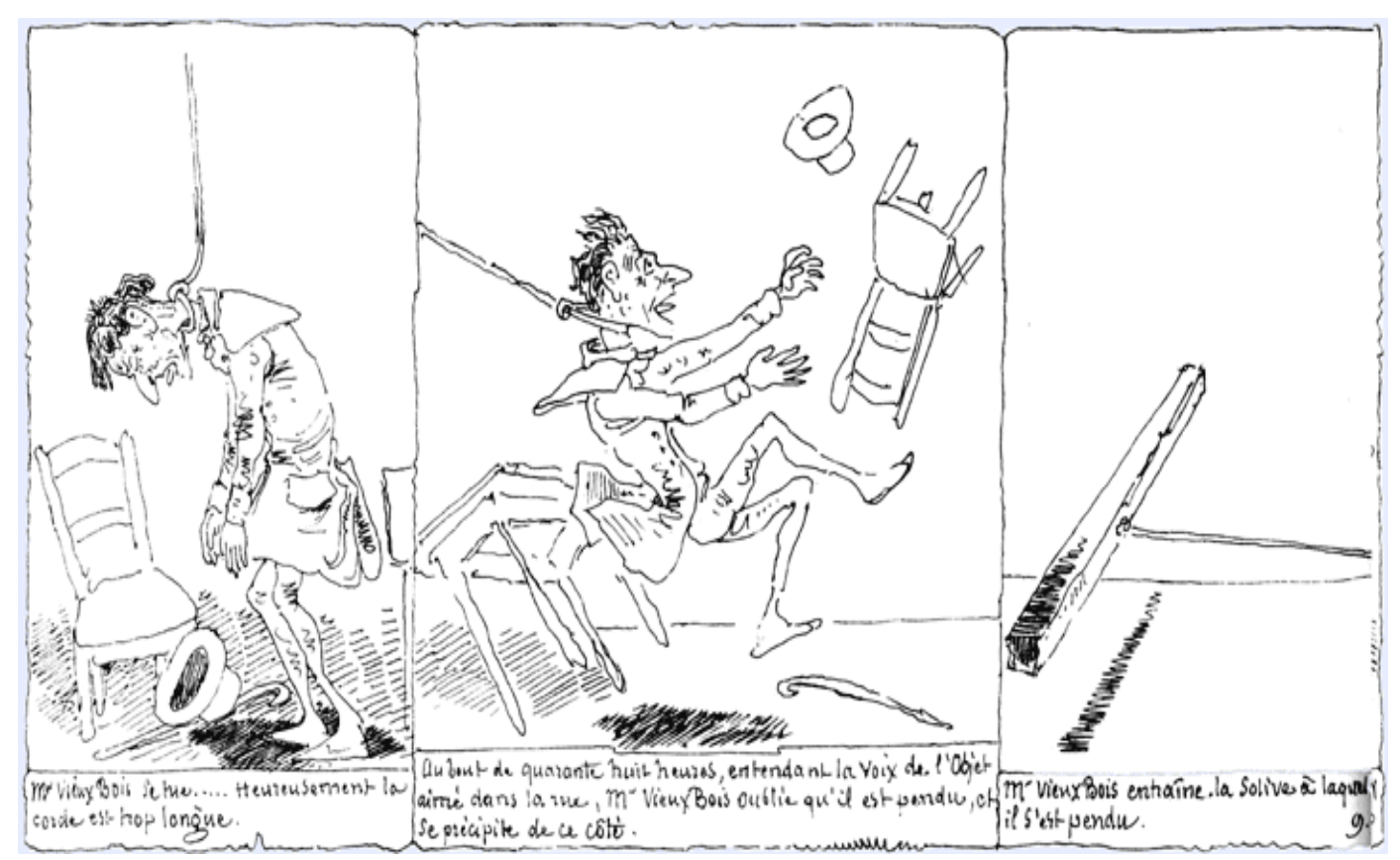

Figura 14 - Les amours de M. Vieux Bois, 1837. A trajetória absurda de M. Vieux Bois em nome do matrimônio, de Rodolphe Topffer. S/n

O pioneirismo de Topffer, contudo, não ofusca outros tantos exemplos que o próprio McCloud nos dá ao argumentar que os quadrinhos são tão antigos quanto a própria civilização. O que se depreende da leitura do primeiro capítulo de Desvendando os quadrinhos, o primeiro livro da trilogia do autor, é que são fartos os casos onde é possível identificar vestígios de uma narrativa sequencial: na arte rupestre das cavernas em Lascaux feita pelo homem pré-histórico (séc. 170 a.C.), nas centenárias tapeçarias francesas de Bayeux, do séc. XI, que mediam 70 metros e contavam histórias que deviam ser lidas da esquerda para a direita; nos painéis do século $\mathrm{XV}$, contando as torturas de Santo Erasmo; no manuscrito pré-colombiano descoberto por Cortés, em 1519, com suas imagens em ordem sequencial e nítida preocupação narrativa; e no conjunto de ilustrações já mencionadas aqui, de William Hogarth, intitulado $O$ progresso de uma prostituta, pouco antes da metade do século XVIII, para citar alguns exemplos.

Os exemplos acima são poucos mas dão pequena mostra da diversidade de perspectivas disponíveis sobre quadrinhos. Não sendo este, contudo, o objetivo dessa pesquisa, o que se procurou apontar como crítico é que muitas propostas de análise dos quadrinhos estão interessadas em encontrar um conjunto de elementos 
que constitua a especificidade dessa arte. $\mathrm{O}$ esforço empreendido em elencar e dissecar esses elementos resulta em abundância de elementos descritivos, muitas vezes analisados em contraste binário com elementos descritivos de outras artes, ricos em terminologias, mas que pouco acrescentam à compreensão mais ampla da arte sequencial e suas potencialidades.

Qualquer tentativa de identificar o criador da chamada "nona arte" revela, no entendimento desta dissertação, portanto, em premissa, uma expectativa equivocada. Não há nas artes, como não há, por conseguinte, nos quadrinhos, uma especificidade de contornos precisos. Não se trata de encontrar um critério que normatize e seccione indubitavelmente o que é e o que não é quadrinho.

A definição de quadrinhos mais coerente à proposta de análise desta pesquisa é, portanto, a que lhes reconhece fundamentalmente a dimensão estética, mas não os asfalta a uma mídia específica, sejam livros, jornais ou revistas. É também a que se faz sensível às relações de intermidialidade dos quadrinhos com outras artes e se mostra atenta ao fato de que o "nascimento" dos quadrinhos é algo em boa medida impossível de se precisar, pois cada exemplo eleito "pioneiro" é herdeiro de outro que lhe precede, e nele ancora as condições de possibilidade de sua emergência.

Com relação à escolha do termo "quadrinhos", e não do termo "romance gráfico", valem algumas observações. A problematização do termo "romance gráfico" aponta em várias perspectivas e um posicionamento crítico em relação a ele pede a ponderação dos aspectos históricos juntamente com os aspectos ligados à intermidialidade. Inicialmente, cogitou-se adotar a expressão "romance gráfico" nesta pesquisa. Em princípio, a vantagem de assim proceder seria referir-se a um recorte selecionado dentro do universo mais amplo dos quadrinhos, um recorte cujo critério seria a remediação da literatura referenciada no termo "romance". No entanto, em um segundo momento considerou-se que a restrição poderia produzir um recorte em contradição com a proposta desta dissertação de adotar o viés da arqueologia da intermidialidade como proposta dentro dos estudos de intermidialidade. Além disso, considera-se, neste trabalho não apenas a remediação 
da literatura mas também da pintura. Não havendo motivo para privilegiar uma ou outra relação de remediação, considerou-se mais harmonioso à proposta metodológica deste trabalho a adoção do termo "quadrinhos".

A forma sequencial antes de ganhar a identidade impressa que nos faz identificá-la imediatamente às revistas e publicações de "histórias em quadrinhos" foi experimentada em diferentes mídias e artes. Ganhou, enquanto mal se tinha consciência dessa forma, propostas estilísticas nas pinturas e gravuras ao longo de muitos séculos, foi experimentada em jornais e revistas no século XIX e chamou a atenção das artes plásticas, sobretudo da pintura nas primeiras décadas do século XX, como continua a chamar a atenção até hoje.

A remediação de outras artes pelos quadrinhos, contudo, ganha maior amplitude e interesse quando se torna pública a categoria de "romance gráfico". Não é que essa operação de remediação não tenha se dado antes no campo dos quadrinhos. Mas na medida em que se criam as bases para a instituição de um selo, de um mercado com público alvo, aumenta o número de trabalhos motivados em experimentar novos usos para a mesma mídia.

Nos últimos 30 anos, o termo "romance gráfico" começou a ser largamente usado. Sua origem, ao contrário do que alguns acreditam, não mantinha um plano de superação de seu antecedente, a expressão "histórias em quadrinhos". Nada há de concorrente entre as duas categorias, já que o termo romance gráfico não se circunscreve em fronteiras rígidas e mensuráveis, ao contrário, é capaz de abarcar (quase) todas as obras que assim se autodeterminem. Todo romance gráfico é uma história em quadrinhos, embora nem toda história em quadrinhos se apresente como um romance gráfico.

O surgimento do termo "romance gráfico" esteve relacionado à necessidade, de autores e, posteriormente, de editores de fanzines, de flexibilizar a forma dos quadrinhos e categorizá-los diferentemente na intenção de chamar atenção para essas novas apropriações (referentes ao tamanho do livro, à extensão da obra, aos temas, ao público alvo). Ao contrário do que argumentam os que repudiam o termo por considerá-lo elitista - um afirmador das relações de poder exercido pelo cânone 
na tentativa de angariar prestígio a um gênero discriminado -, defende-se aqui que a expressão romance gráfico resulta do desejo de alguns autores de investir atenção no diálogo dos quadrinhos com outras artes, adentrando pela porta da frente mesmo que precisando de um crachá - no seleto salão das artes. Aproveitando ainda a metáfora, não foi, portanto, o crachá "romance gráfico" que levou os quadrinhos ao patamar de arte, foi a experimentação de novas linguagens que levou os quadrinhos a adotarem um novo "crachá" para facilitar a sua circulação e aceitação entre as artes. Aparentemente parece tratar-se da mesma coisa, mas não é, pois é a própria adoção do termo que aponta para a reivindicação de alguns autores de chamar a atenção para os experimentos de linguagem em que vinham investindo, bem como criar um espaço receptivo para eles.

Will Eisner tinha plena consciência de estar testando novas possibilidades de linguagem. No início talvez tenha apenas desejado aderir à sua época e contestar o status exclusivo de arte de alguns objetos. Nesse momento, tentou promover abertamente o debate provocando seus pares, muitos deles velhos e consolidados nomes no mercado das comics, a considerar os quadrinhos como arte. A reação foi defensiva e conservadora. E Eisner só voltou ao tema 50 anos depois, já então consolidado entre os autores conhecidos, emplacando o nome "romance gráfico" para nomear seu trabalho. Antes dele, Richard Kyle já havia se referido ao termo "estórias gráficas"3 em um contexto, no entanto, ainda pouco receptivo, em que os quadrinhos buscavam se consolidar no mercado e expandir seu alcance pelo mundo, como aconteceu nos EUA.

Valoriza-se aqui a lenta gestação dos romances gráficos na mídia impressa e a dupla resistência encontrada: tanto entre autores consagrados (que consideravam os quadrinhos não deveriam jamais ser outra coisa além de entretenimento, vaudeville) quanto pelo próprio mercado, em certa medida, pouco receptivo às inovações já que havia encontrado nos gibis e revistas de fácil apreensão um público cativo.

\footnotetext{
${ }^{3}$ Disponível em: <http://www.tcj.com/richard-kyle-in-retrospect/> e <www.bleedingcool.com/2016/12/12/richard-kyle-man-named-graphic-novel-died-weekend/>
} 
O termo romance gráfico, se olhado pelo viés de uma arqueologia da intermidialidade, faz, portanto, referência à remediação da literatura pelos quadrinhos. Originalmente, não foi por outra motivação, que alguns autores e apreciadores começaram a usar essa expressão. Que ela tenha sido capitalizada, posteriormente - sobretudo após a premiação de Maus, de Art Spiegelman, com o prêmio Pulitzer - por interesses de mercado, visando oportunidades bastante evidentes de ampliação do escopo de leitores do gênero, essa é uma outra questão pertinente, porém, fora do radar de interesses dessa pesquisa.

De qualquer forma, em nenhuma das duas hipóteses (a do autor ou a do mercado) parece haver espaço para uma visão autônoma dos quadrinhos. A defesa de qualquer purismo na arte dos quadrinhos seria amplamente descabida e, considerando historicamente o pensamento sobre a relação entre as artes, anacrônica. Os quadrinhos, como se nota claramente em seu processo de institucionalização nasce impuro, híbrido, desde sempre. Assim, portanto, a ideia não seria a de "misturar" quadrinhos e literatura e dar a isso o nome de "romance gráfico" para destacá-lo ou elitizá-lo, e sim outra: dar o nome de "romance gráfico" aos trabalhos que insinuam vestígios dessa relação, tornando-a em geral menos transparente, como se procedessem com uma espécie de metalinguagem das mídias.

Com efeito, vale enfatizar que a hipótese crítica ao termo "romance" no binômio "romance gráfico" - sob o argumento de elitismo - mostra-se frágil diante do que se sabe historicamente, acerca da origem da expressão "romance gráfico", e além disso bastante insuficiente para sustentar a compreensão da emergência recente de novas categorias dentro dos quadrinhos, incluindo as chamadas Hqtrônicas.

A expressão "romance gráfico" teve nascimento truncado, difícil, e sujeito a censuras e ridicularizações. A ideia de aproximar quadrinhos e artes no mercado editorial havia surgido na década de 1930, quando Will Eisner conheceu narrativas em quadrinhos mais longas, sem palavras, feitas em serigrafia. Enquanto isso, na mesma década, na pintura - como se retomará mais adiante -, por sua vez, Picasso mostrava-se bastante interessado na linguagem dos cartoons em suas pesquisas. Essa influência lhe chegou por Gertrudes Stein que, em visita a Picasso, levou-lhe 
de surpresa um pacote de jornais onde havia o suplemento dominical de papéis americanos, os filhos Katzenjammer. ${ }^{4}$

Voltando a Eisner, é clara sua motivação, como também a de Richard Kyle (a quem se atribui a cunhagem do termo "estória gráfico), de encontrar um termo que os diferenciasse dos comics bem como dos limites a que estavam sujeitos, fossem temáticos, fossem etários ou formais - tamanho dos quadros, tamanho das histórias, entre outros.

No Brasil, a expressão começou a ser cunhada por volta de 1988 e teve como marco a publicação da série Graphic Novel, pela Marvel e DC Comics.

$\mathrm{O}$ número de estreia trazia uma história do supergrupo X-Men, intitulada $\mathrm{O}$ Conflito de uma Raça. O diferencial da publicação era ter sido editada em tamanho maior e com papel especial (tinha 68 páginas ao todo). Prevaleceu o grampo para prender as páginas, o que assemelhava o produto a uma revista. Outro fator de semelhança era as vendas serem feitas em bancas de jornal (RAMOS, FIGUEIRAS, s/d, p. 5)

Se, por um lado, o termo surgiu entre criadores, por outro, rapidamente se viu capitalizado pelo mercado. Sobre isso, Ramos e Figueira afirmam:

Era mínimo o diálogo regular dos quadrinhos com as livrarias. Os poucos casos se pautavam em edições europeias, casos de As Aventuras de Tintin e Asterix, ambos na década de 1970, pela editora Record. Na mesma década e na seguinte, a gaúcha L\&PM também enveredou pelas publicações nacionais e de diferentes países em formato livro, voltadas às livrarias. A editora fazia questão de chamar as edições de quadrinhos. Tanto que o nome da série era Coleção Quadrinhos L\&PM. Outro termo para se referir a edições assim foi álbum. Vê-se, portanto, que, enquanto a expressão graphic novel ainda era popularizada nos Estados Unidos, outros países já mantinham uma produção de narrativas em quadrinhos mais longas, em particular os europeus. O Brasil já refletia tais produções em obras produzidas em formato livro, chamadas de álbuns. O termo norte-americano parece ter sido uma resposta própria da indústria do país a esse molde de criação de histórias em quadrinhos. (Ibid, ibidem)

\begin{tabular}{llll}
\hline $4 \quad$ Relato $\quad$ extraído & da $\quad$ matéria & publicada & em \\
www.theguardian.com/books/2002/apr/13/books.guardianreview1 & & \\
5 & Disponível & em:
\end{tabular}


Vale a pena, para finalizar esta seção, trazer para essa discussão o Manifesto de Eddie Campbell, escrito em 2010. O documento criado pelo desenhista Campbell dá boa mostra de que a terminologia romance gráfico embora suscite algum interesse por parte dos criadores não constitui sua preocupação permanente e muito menos se põe acima do que a própria linguagem tem a oferecer.

1. Romance gráfico é um termo desagradável, mas vamos usá-lo de qualquer maneira esclarecendo a compreensão de que "gráfico" nada tem a ver com os gráficos e que a "romance" não significa nada a ver com "romance". (da mesma forma que o "impressionismo" não é realmente um termo aplicável, na verdade, foi usado pela primeira vez como um insulto e depois adotado com espírito de desafio.)

Um tom de ironia, mais ou menos acentuado, está presente nos diferentes tópicos, e desmistifica por completo a ideia de que o termo tenha surgido como estratégia de poder. Campbell afirma que a escolha do termo não se deve ao fato de ser a expressão "romance gráfico" uma boa expressão, mas, sim, à falta de um termo melhor.

2. Já que não nos referimos ao romance literário tradicional, não consideramos que o romance gráfico deva ter a mesma dimensão tampouco peso físico. Assim, termos subsidiários como "novela" e "folhetim" não são úteis aqui e somente servirão para confundir os espectadores quanto ao nosso objetivo (veja abaixo), fazendo com que pensem que estamos criando uma versão ilustrada da literatura padrão quando, na realidade, temos peixes maiores para fritar - em outras palavras, estamos forjando uma arte totalmente nova que não será escrava das regras arbitrárias de uma antiga.

Distanciando-se da pretensão canônica, o manifesto reivindica em um só gesto a preservação da leveza e a independência dos romances gráficos em relação a amarras de outras referências midiáticas.

3. Romance gráfico significa movimento; e, não, uma forma. Assim, podemos nos referir aos trabalhos de xilogravura ${ }^{7}$ de Lynd Ward como antecedentes do romance gráfico, mas não nos interessa aplicar retrospectivamente o termo para chamá-los de "romances gráficos"

4. Embora o romancista gráfico reconheça seus vários antecedentes como gênios e profetas, influências sem as quais eles não poderia criar o que criou, ele não quer

\footnotetext{
${ }^{6}$ No original "novella and novelette".

${ }^{7}$ No original, woodcut novels.
} 
ser obrigado a estar sempre atrás do progresso de Rake, de William Hoggarth quando ganha um pouco de publicidade com sua arte.

5. Uma vez que o termo significa um movimento, ou um evento contínuo, em vez de uma forma, não há nada a ser obtido definindo-o ou "medindo-o". Tem aproximadamente trinta anos de idade, mas o conceito está em vigor há muitos anos. Como ainda está crescendo no próximo ano.

Os itens 3,4 e 5 talvez sejam os mais importantes do manifesto no que se refere à intermidialidade. A referência a um "ancestral" intermidiático (a xilogravura de Ward, os trabalhos de Hoggarth), cujos vestígios se fazem perceber ainda hoje em tantas propostas experimentais, não autoriza a aplicação retroativa do termo, pois o que importa não é o congelamento do movimento das mídias, e, sim, seu movimento, sua dinâmica, fluída de remedições. Campbell não busca anular as relações históricas que são parte da constituição das mídias.

6. O objetivo do romancista gráfico é assumir os quadrinhos como forma, o que se tornou um constrangimento, e elevá-lo a um nível mais ambicioso e significativo. Isso normalmente envolve aumentar sua extensão, mas devemos evitar de entrar em discussões sobre o tamanho permitido. Se tivermos um novo romance feito de histórias curtas (como Eisner fez com o "Contrato com Deus"), não devemos reduzir a questão, devemos apenas nos perguntar se seu novo romance gráfico é um conjunto bom ou ruim de histórias curtas. Se o romancista ou a romancista usa personagens que aparecem em outros lugares, como é o caso de Jimmy Corrigan fora do livro principal, ou Gilbert Hernandez, etc. ou mesmo personagens que não queremos permitir dentro de nossa "sociedade secreta imaginária", não devemos descartá-los por causa disso. Se o trabalho deles não se parece com um romance gráfico, tampouco devemos questioná-los por isso. Só devemos nos perguntar se esse trabalho expande a soma total da sabedoria humana.

Neste item 6, Campbell reivindica carta branca, sem fidelidades sem sentido, a qualquer materialidade. Um elogio ao experimentalismo.

7. O termo romance gráfico não deve ser tomado para indicar um formato de comércio (um 'formato de prestígio'). O importante neste termo é o intento, mesmo que ele só nos chegue após a publicação original.

8. Os romancistas gráficos assumem como tema tudo o que diz respeito à existência humana, incluindo sua própria vida. Ele ou ela desdenha dos clichês de "ficção de gênero", embora tentem manter uma mente aberta. Ficam particularmente aborrecidos com a noção, ainda prevalecente em muitos lugares, e não sem razão, que o livro de quadrinhos é um subgênero da ficção científica ou da fantasia heroica. 
Mais uma vez, nega-se a forma pré-determinada e afirma-se a liberdade de experimentação, o que inclui a aceitação de qualquer tema pode ser assunto do romance gráfico.

9. Um romancista gráfico jamais pensará em usar o termo romance gráfico quando estiver conversando com seus colegas. Eles provavelmente se referirão ao seu "último trabalho" ou ao seu "processo de trabalho" ou mesmo simplesmente "aos quadrinhos" que têm feito. O termo deve ser usado como um emblema ou uma bandeira antiga que é trazida para a batalha ou quando para indicar a localização de uma determinada prateleira de livraria. Os editores podem usar o termo repetidamente até que venha a significar menos do que hoje significa. Além disso, os romancistas gráficos estão bem cientes de que a próxima geração de cartunistas escolherá trabalhar nas menores formas mais possíveis e nos ridicularizará por nossa pomposidade.

10. O romancista gráfico se reserva o direito de negar qualquer um dos itens acima se isso levar ao aumento de vendas de seus livros.

Nestes dois últimos itens, Campbell reconhece que houve apropriação do termo por parte do mercado mas não vê problema, desde que isso resulte em maior visibilidade e lucratividade.

Se o termo "romance gráfico" nomeia a remediação da literatura pelos quadrinhos, vale reconhecer que a remediação antecede sua nomeação e data do início do século XX, quando se procurou investir na tentativa de instrumentalizar os quadrinhos a serviço da educação literária e se procedeu com a adaptação de inúmeros clássicos da literatura. A tematização do próprio ofício da escrita constituiu outra forma de remediar a literatura. O reconhecimento de que as condições para o diálogo entre literatura e quadrinhos não se encontram em um momento histórico preciso e de desenvolvimento linear, mas podem ser percebidas no reconhecimento da constante remediação de outras artes pelos quadrinhos (bem como dos quadrinhos por outras artes e mídias) é o que encoraja este estudo a considerar que a perspectiva de uma arqueológica da intermidialidade seja aplicável ao estudo quadrinhos.

Neste trabalho, fez-se a opção por não trabalhar com exemplos históricos e, sim, com um experimento teórico capaz de acender as relações intermidiáticas dos quadrinhos. Tal escolha pautou-se na compreensão de que no caso dos quadrinhos, 
a montagem pode nos dar o lugar privilegiado da cena de remediação dos quadrinhos.

A definição de quadrinhos que se quer alcançar aqui, portanto, não busca levantar fronteiras e especificidades, mas, sim, reconhecer que os quadrinhos não são a invenção de um autor específico - eles resultam de um mesmo Zeitgeist, um desejo de experimentação, fruto de uma longa tradição de diálogo entre as artes que remonta ao ut pictura poiesis.

No capítulo seguinte, apresentam-se, a partir da esquematização feita por Scott McCloud, as principais categorias de montagem identificadas nos quadrinhos. Em vista do que foi escrito até o momento, é cioso dizer que essas categorias não configuram uma lista exaustiva das operações de montagem nos quadrinhos a partir da sarjeta. Em vez, disso, o que fazem é mapear um esquema claro e enxuto, dando conta de abarcar as principais operações experimentadas nos quadrinhos responsáveis por conduzir o olhar de um quadro a outro, de completar o não-visível, de conectar a leitura do intervalo (como se argumentará mais adiante) de volta à dimensão ficcional dos quadrinhos. Espera-se, assim, mostrar que a sarjeta, como expediente de montagem nos quadrinhos, sobretudo nos casos em que adotam uma linguagem mais experimental e fragmentária, oferece um ângulo privilegiado para pensar a intermidialidade, tornando menos transparente a relação de remediação que os quadrinhos estabelecem com a pintura e a literatura, e cujos vestígios se deixam perceber na leitura do intervalo. 


\title{
Montagem nos quadrinhos
}

\begin{abstract}
"Qual é a essência do trabalho de um diretor? Poderíamos defini-la como 'esculpir o tempo'. Assim como o escultor toma um bloco de mármore e, guiado pela visão interior de sua futura obra, elimina tudo que não faz parte dela - do mesmo modo o cineasta, a partir de um 'bloco de tempo' constituído por uma enorme e sólida quantidade de fatos vivos, corta e rejeita tudo aquilo de que não necessita, deixando apenas o que deverá ser um elemento do futuro filme, o que mostrará ser um componente essencial da imagem cinematográfica".
\end{abstract}

TARKOVSKI, Esculpir o Tempo, 1986

A passagem acima descreve em essência a atividade da montagem seja em que meio for. A montagem, enquanto instância que articula fragmentos, antecede o cinema, e advém do teatro, da literatura, e das artes plásticas, e faz parte do próprio pensamento e sua capacidade de construir sentidos, indo além da mera imitação. Do ponto de vista de sua compreensão histórica, a montagem, como procedimento de composição, tende a minimizar o lado representativo da composição para incorporar a fragmentação como um valor estético.

Neste capítulo propõe-se pensar como os quadrinhos atualizam a estética do fragmento por meio de procedimentos que remediam a pintura e literatura, tornando menos transparentes suas relações de intermidialidade com essas artes. O percurso que se pretende seguir propõe acompanhar o pensamento de Rancière acerca do olhar contido na obra de Johann Joachim Winckelmann, nas últimas décadas do século XVIII, sobre a fragmentação, sobre a falta, a partir do texto em que o historiador e arqueólogo alemão discorre sobre o torso de Belvedere, como um símbolo político da cultura germânica e da perda de sua liberdade. Como este olhar de Winckelmann evidencia a mudança em curso do regime representativo para o estético.

E é precisamente essa mudança, assim identificada, o que interessa a Jacques Rancière investigar. A motivação do filósofo foi querer se opor à visão tradicional que separa uma era representativa e uma era não-representativa, 
tomando como base a passagem da figuração à abstração na pintura: de um lado, um elemento que precisa ser decifrado, interpretado, de outro, a presença que se impõe por si mesma, na ausência de sentido. Rancière diz haver uma tensão entre estes dois pólos, entre a relação do cifrado à decifração e a relação de uma imagem a outra imagem, constitutivo de uma linguagem, e, ao contrário disto, a ideia da não-relação, da presença pura que não traz significados e oferece-se por si mesma.

A valorização e autoafirmação de uma presença sensível impondo-se por si mesma é constitutiva do regime estético. Sobre este regime importante dizer também que, nele, o estatuto da imagem sempre foi contraditório significando a um só tempo: um elemento de um discurso ou uma manifestação cifrada que clama por uma decifração, e de outro, uma presença insignificante que se impõe por si mesma, de maneira que com frequência a ideia de imagem pode se identificar à ideia de ausência de sentido. No próprio centro da ideia da imagem, ocorre uma tensão entre estes dois pólos, entre a relação do cifrado à decifração ou a relação de uma imagem a outra imagem, constitutivo de uma linguagem, e ao contrário disto a ideia da nãorelação, da presença pura a-significativa oferecendo-se por si mesma.

A noção de fragmento, portanto, será aqui calibrada de acordo com o tratamento que lhe deu Jacques Rancière, em Aisthesis, no capítulo intitulado The divided beauty. Neste capítulo, o autor, faz referência à estátua atribuída a Hércules, chamada Torso de Belvedere, hoje parte da coleção de artes do Vaticano. A estátua mutilada do herói dos doze trabalhos apresenta um corpo sentado sem nenhum membro capaz de executar qualquer ação que demande força ou habilidade. Por séculos, artistas diversos tentaram completar a figura, imaginando a ação realizada pelo herói. Rancière chama atenção para o fato de que Johann Joachim Winckelmann, em History of ancient art, publicado em 1764, reverteu esta tradição e, ao invés de reparar a falha, a transformou em uma virtude: não há ação a ser imaginada - a estátua mutilada representa o herói acolhido pelos deuses ao fim de seus trabalhos.

Hércules não é nada além de puro pensamento, porém esta concentração é somente indicada pela curvatura de suas costas que nos faz presumir o peso deste pensamento, 
por um estômago que parece impróprio para qualquer função digestiva e por músculos que não se contraem para nenhuma ação, cuja linhas porém quebram uma sobre as outras como ondas sobre o mar. ${ }^{8}$ (RANCIËRE, 2011, p. 2-3, tradução minha)

Rancière afirma que Winckelmann desloca o que era falha para o lugar da virtude e posiciona o ápice da arte na mutilação, destacando a imobilidade no mais ativo dos heróis, a imobilidade que representa o puro pensamento, como a perpétua oscilação das ondas num calmo oceano.

Winckelmann possuía uma intenção polêmica com a publicação de seu livro. Ele queria lembrar seus contemporâneos dos verdadeiros modelos da beleza, tirando-os dos excessos da escultura moderna - isto é, em seu tempo, a escultura barroca: corpos excessivamente estendidos ou retorcidos, faces distorcidas com a intenção de traduzir prazer ou dor extremos. (...) Winckelmann é desta forma reconhecido como o guardião retrógrado de um ideal clássico de impassibilidade divina e beleza que reside em linhas puras e proporções harmoniosas. Tornar-se-ia assim o pai do estilo neoclássico de escultura, triunfante durante a era napoleônica, incorporadas pelas figuras frígidas esculpidas em mármore de Canova. ${ }^{9}$ (Ibid, ibidem, tradução minha)

Distanciando-se do regime representativo da expressão artística, o Torso do Belvedere, tal como descrito por Winckelmann, apresenta a estátua de Hércules, mas não a do herói potente, e sim a de um herói sem rosto e sem membros para executar qualquer ação, um herói cujos sentimentos não se emprestam à representatividade. Nos músculos do Torso, o movimento igualado ao repouso, o trabalho de Hércules igualado à ociosidade. Assim, Winckelmann esperava aludir à beleza perdida, à liberdade perdida do povo grego. A neutralização da oposição entre a atividade e a passividade, isto é, da partilha do mundo entre a classe dos

\footnotetext{
${ }^{8}$ No original, "he is nothing but pure thought, but this concentration is only indicated by the curve of a back that assumes the weight of this thought, by a stomach that seems unfit for any digestive functions, and by muscles that do not tighten for any action, but whose outlines flow over each other like the waves of the sea."

${ }^{9}$ No original, "Winckelmann had a polemical intention in publishing his History. He wanted to remind his contemporaries of the true models of beauty, drawing them away from the excesses of modern sculpture - that is to say, in his time, baroque sculpture: excessively extended or twisted bodies, faces distorted by the will to express extreme pleasure or pain. (...) Winckelmann to a certain role: he is made the retrograde guardian of a classical ideal of divine impassibility and beauty residing in pure lines and harmonious proportions. He would thus be the father of the neoclassical sculpture triumphant during the Napoleonic era, embodied by Canova's frigid marble figures."
} 
homens ativos, que são os homens do ócio e do lazer e a dos homens passivos, a dos homens destinados à passividade do trabalho reprodutor.

O que Rancière destaca, portanto, em Winckelmann, é a ruptura com dois critérios essenciais à ordem representativa: por um lado, a harmonia das proporções, que é a congruência entre as partes e seu todo; e, por outro, a expressividade, a relação estabelecida entre uma forma e um conceito, uma identidade, um sentimento, uma ideia. Assim sendo, reconhece ali a aceitação de uma impossibilidade, qual seja, a de julgar se os braços e pernas deste Hércules estavam ou não em harmonia material com o restante de seu corpo ou se estes membros, assim como sua face, estavam em harmonia espiritual com os traços descritos em seus mitos. De forma ainda mais radical, será para sempre impossível determinar se realmente é Hércules o representado, uma vez que não estão presentes os atributos que o fariam reconhecível.

A despeito das controvérsias acerca do Torso de Belvedere - afinal, muitos, posteriormente, debateram as afirmações de Winckelmann, afirmando ora que o Torso era uma reprodução dos tempos romanos, ora que buscava representar não um Hércules no Panteão dos deuses gregos, mas, sim, um Filoctetes em sofrimento, o que Rancière procura destacar é que Winckelmann, a um só tempo, afirma sua lealdade a um ideal ultrapassado de perfeição estética e também propõe a revogação do princípio que ligou a aparência da beleza com a realização de uma ciência de proporção e expressão. No Torso, o corpo completo aponta para a falta, tanto quanto sua expressão também o faz. Esta perda acidental corresponde à uma quebra estrutural de um paradigma de perfeição artística.

Para discutir como se chegou a uma estética dos fragmentos, Rancière resgata uma antiga preocupação de acadêmicos e artistas por quase um século - a de como relacionar o ideal da harmonia das figuras com a expressão de paixão. Tal questão, vista como um problema técnico entre estudiosos e aprendizes das artes, consistia em identificar em uma obra não só a forma e os traços dos modelos nos estúdios, mas, também, as paixões e sentimentos dos personagens que deviam ser representados. Paixões e sentimentos que, tanto o modelo quanto o artista não haviam, de fato, experimentado. Havia a ideia de que o ateliê deveria ser 
abandonado pelo artista para estudar as paixões e sentimentos que deviam ser traduzidos na obra por outros meios. E alguns acreditaram que entre esses meios poderia estar o teatro, enquanto outros discordavam dessa abordagem, afirmando que até mesmo na melhor das atuações os pintores encontrariam apenas caricaturas e atitudes forçadas com expressões artificialmente construídas, que não refletiam os sentimentos que os artistas buscavam compreender. Por outro lado, as ruas e oficinas eram os melhores ambientes para a observação do homem comum, ainda intocado pela conformidade expressiva das convenções mundanas, como confirmaram os precursores das histórias em quadrinhos, Topffer e Hoggarth.

A beleza do Laocoonte, segundo identificou Rancière na leitura de Winckelmann, não vem da multiplicidade das paixões que ele expressa, mas sim da neutralização delas na tensão de dois movimentos opostos: um que aceita e abraça a dor e outro que a rejeita. O Laocoonte oferece a complexa forma da fórmula, que toma sua mais simples forma na insuficiência radical no Torso Belvedere: a beleza é definida pela indeterminação e a falta de expressividade. E é isso o que chama atenção de Rancière, eles queriam elevar a honesta expressão dos pensamentos e paixões acima dos princípios formais de harmonia e proporção.

A análise de Winckelmann do Torso, segundo Rancière, parece ir precisamente contra a corrente estabelecendo uma contra revolução de expressão suspendida contra uma total revolução na expressão. No entanto, essas duas revoluções opostas compartilham um princípio em comum: a destruição do que é a essência da lógica representativa - o modelo orgânico do todo, com todas suas proporções simetrias. Winckelmann defendia a superioridade de linhas curvadas e imperfeitas, em contraste com linhas rígidas. Foi essa a imagem que usou para descrever o Torso: músculos derretidos um sobre o outro como ondas quebrando na praia. A bela estátua é aquela onde os músculos não estão tensionados, porém relaxados, lembrando as calmas ondas do mar, ou a superfície lisa de um espelho.

Para Rancière, Winckelmann inaugura a era na qual artistas estavam ocupados revelando o potencial sensível escondido na inexpressividade, imobilidade e passividade. Mesmo reduzido a um mero esboço muscular, similar a ondas, com seus traços derretendo uns sobre os outros, o Torso é esteticamente superior ao Laocoonte, forçado a mostrar em seu rosto a dor causada na mordida e 
a força da alma que a ela resiste. A estátua mutilada celebrada por Winckelmann, no entanto, ela não é mais uma ideia de adição, mas de subtração.

Rancière afirma que a teorização kantiana da beleza sem um conceito quebra com a ideia do suplemento porque ela primeiramente quebra com a ideia de sua correspondência. Quanto menos expressões da academia forem reproduzidas na obra, mais beleza ela possuirá. Isso requer uma divisão, não uma adição, entre os conceitos que a arte implementa e o belo sem um conceito. É o poder, diz ele, que permanece obscuro ao artista, de fazer algo além do que ele faz, ou produzir algo diferente do que ele quer produzir, dando assim ao leitor, o espectador ou o interlocutor a oportunidade de reconhecer e, diferentemente, combinar muitas superfícies em uma só, muitas linguagens em uma frase, e muitos corpos em um simples movimento.

A separação entre as razões da arte e as da beleza fazem com que arte exista como tal, como seu próprio mundo, e não simplesmente como a habilidade do artista. Para Rancière, Winckelmann foi um dos primeiros, se não o primeiro, a inventar a noção da arte como nós a entendemos: não mais como uma habilidade daqueles que fazem as pinturas, estátuas ou poemas, mas como um conjunto sensível da coexistência de seus trabalhos.

O que realmente importa é pensar na coexistência da obra de um artista e os princípios que governam a vida de seu povo e de seu tempo. Um conceito captura este nó em seu trabalho: o conceito de "estilo". O estilo manifestado no trabalho de um escultor pertence a um povo, a um momento de sua vida e ao desenvolvimento de um potencial de liberdade coletiva. A arte existe onde pode ser feito um povo, uma sociedade, uma era, tomada em um certo momento no desenvolvimento de sua vida coletiva, seu sujeito. A harmonia "natural" entre poiesis e aesthesis que governou a ordem representativa é oposta a uma nova relação entre a individualidade e a coletividade, entre a personalidade do artista e o mundo compartilhado que ela expressa.

$\mathrm{O}$ acesso de Rancière à obra de Winckelmann se faz por uma espécie de leitura do intervalo. O autor alemão coloca a suprema encarnação da Grécia, que identifica como berço germânico, em uma estátua que não possui cabeça ou 
membros. O corpo grego que Winckelmann deixou como um legado para posterioridade é definitivamente um corpo fragmentado, separado de si mesmo e de toda atividade. Winckelmann arruinou a presunção de uma harmonia entre a capacidade de ação e a perfeição formal (defendia a separação, a fragmentação), enquanto a polêmica de Rousseau deslocava tal questão para um território ético (atividade). Separação e inatividade são propriamente as características antissociais do palco performativo, diz Rancière. Winckelmann opõe a mediação representativa não à comunidade ética, mas à fragmentação. $\mathrm{O}$ fragmento é a virtude paradoxal de um estado mutilado, de acordo com Winckelmann. O mais importante, diz Rancière, é negar a oposição entre a figura do deus e a do herói super-humano. A Grécia resgatada é somente presente na forma de uma insuficiência.

Adentrando no campo dos quadrinhos e as questões de montagem que lhe cercam, propõe-se aqui compreender como os quadrinhos atualizam a estética do fragmento por meio de procedimentos que remediam a pintura e literatura, tornando menos transparentes suas relações de intermidialidade com essas artes. Pretende-se argumentar que, sendo fruto de um longo processo histórico de remediação da pintura e da literatura, os quadrinhos em suas versões mais experimentais, retomam a tensão explicitada por Rancière, explorando-a e atualizando-a em formas híbridas, que misturam interpretação e ausência de sentido, unidade e fragmentação.

Para tanto é conveniente neste momento apresentar o quadro esquemático oferecido por Scott McCloud em que o autor propõe uma sistematização sucinta e bem elaborada dos tipos de operação de sarjeta que existem. O que se está chamando aqui de operações de sarjeta são as operações de leitura responsáveis por construir relações entre dois quadros. Ou seja são as operações que nos levam a perceber o todo onde apenas partes são reveladas. McCloud chama de "conclusão" (2005:64) ao processo mental capaz de reunir fragmentos e ver o conjunto da cena na imaginação. Aqui chamar-se-á de montagem, assumindo-a no entanto não somente como dado da produção, mas também da recepção. Com a fotografia, por exemplo, não é outra coisa que acontece. Nossos olhos veem pontos preto e brancos fragmentados em retículas, e nossa mente transforma esses pontos em realidade.

Os quadrinhos constituem um meio onde o público é colaborador consciente e voluntário dessa operação. Quanto maior a descontinuidade entre uma imagem e 
outra, maior a participação demandada ao leitor. Quando o fio narrativo da ação perde sua primazia o que normalmente acontece é que outras relações mais silenciosas estão sendo requeridas:

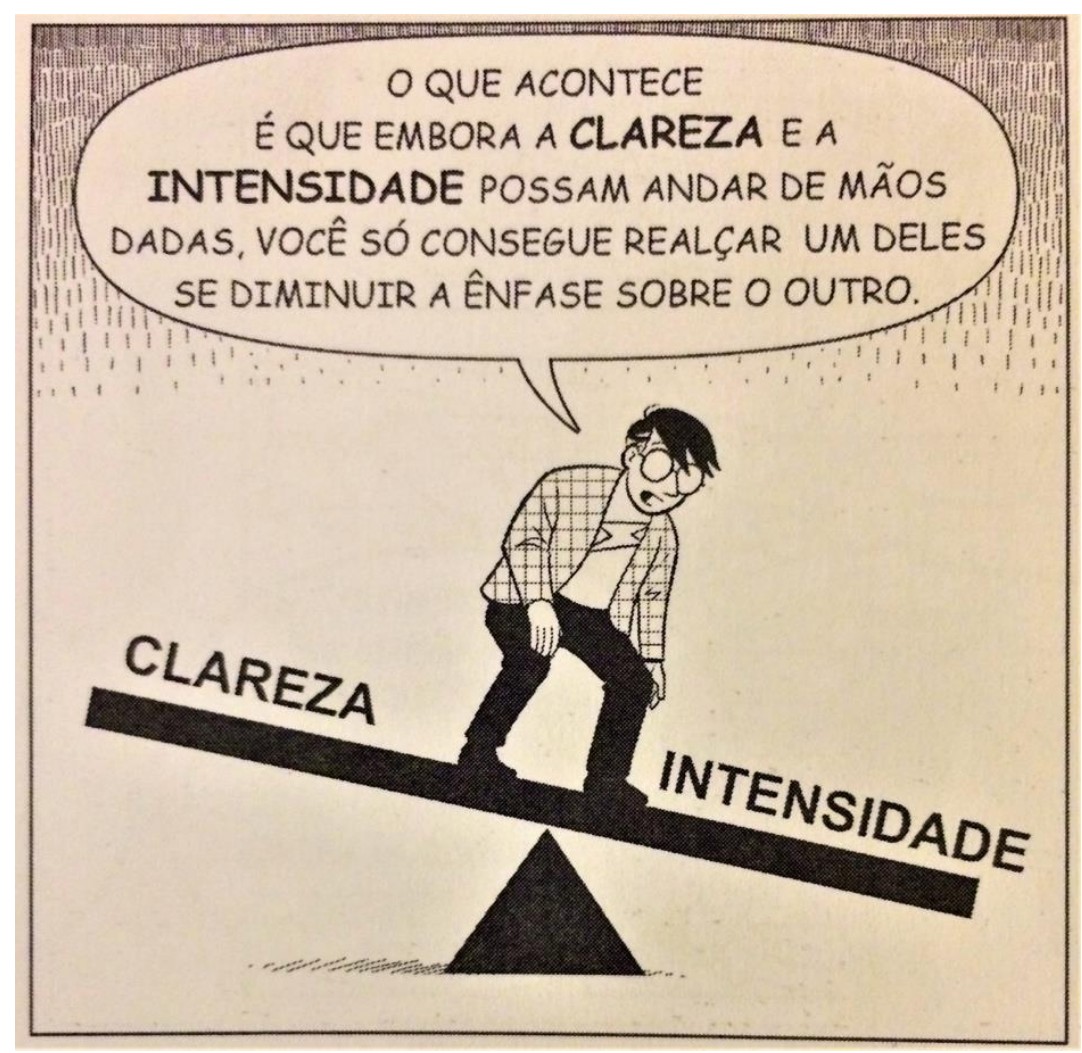

Figura 15 - Desenhando quadrinhos, de Scott McCloud

McCloud (2005, p. 67) afirma que "os quadros das histórias fragmentam tempo e espaço, oferecendo ritmo recortado de movimentos dissociados." E o que está entre um quadro e outro cabe à leitura, uma leitura que remete a elementos externos aos próprios quadrinhos. E a imaginação do leitor é parte constitutiva da leitura que ele faz.

McCloud sustenta que, por mais fragmentadas que sejam as imagens que compõem uma sequência, haverá sempre por parte do espectador algum movimento em direção a enxergar alguma identidade entre imagens, um sentido de continuidade. Ou seja, o espectador/leitor naturalmente se sente convocado, uma vez sugerida a composição ou a sequência, a produzir um sentido de todo, e a criar 
uma visão de conjunto. Quanto mais fragmentadas as imagens, maior, naturalmente, a dimensão intervalar entre elas.

O autor afirma que, por tradição, os quadrinhos orientais tendem a zelar mais por essas transições entre imagens mais fragmentadas:

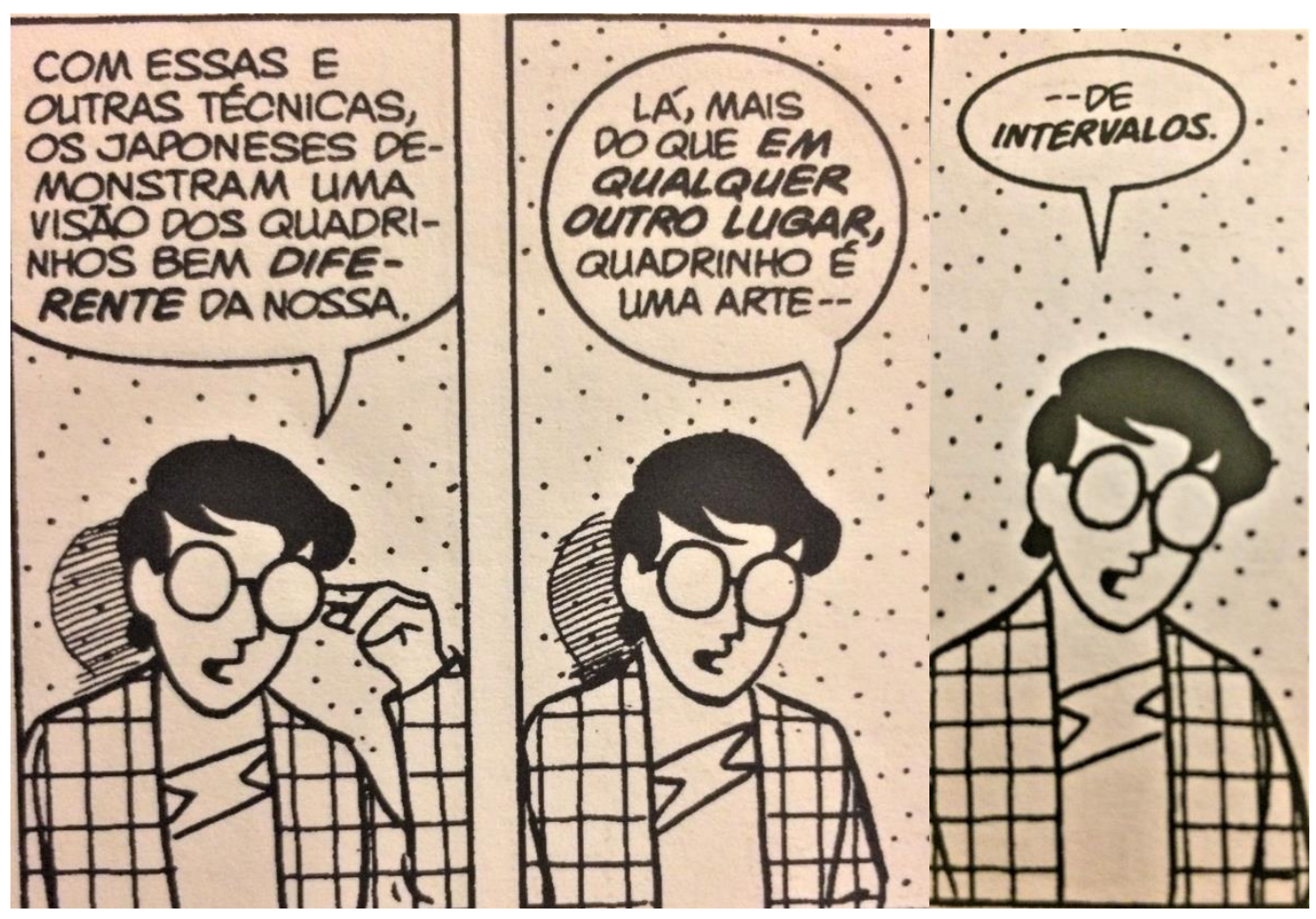

Figura 16 - Desvendando os quadrinhos, de Scott McCloud

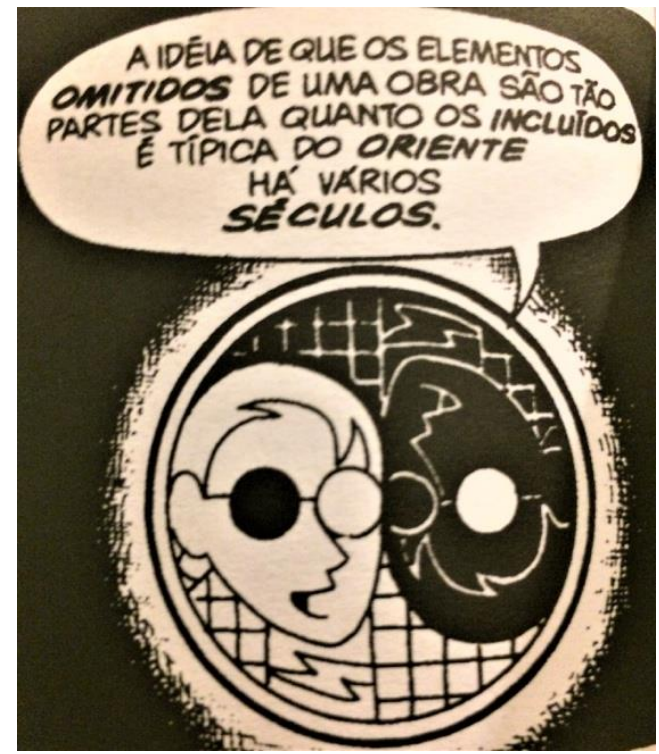


Figura 17 - Desvendando os quadrinhos, de Scott McCloud

A referência de McCloud à fragmentação característica de certas obras reforça a estratégia em fazer o intervalo falar, o não-dito, o não mostrado. $\mathrm{O}$ universo de amostragem reúne seis autores renomados. Cada uma das colunas verticais corresponde a um tipo de transição (como se verá mais adiante), A quinta coluna, adianta-se aqui, corresponde à transição de aspecto para aspecto, e é normalmente menos comum nos quadrinhos em geral por seu caráter mais errático, com menos ênfase na passagem de tempo que na intenção de dirigir o olhar para diferentes aspectos de uma cena.

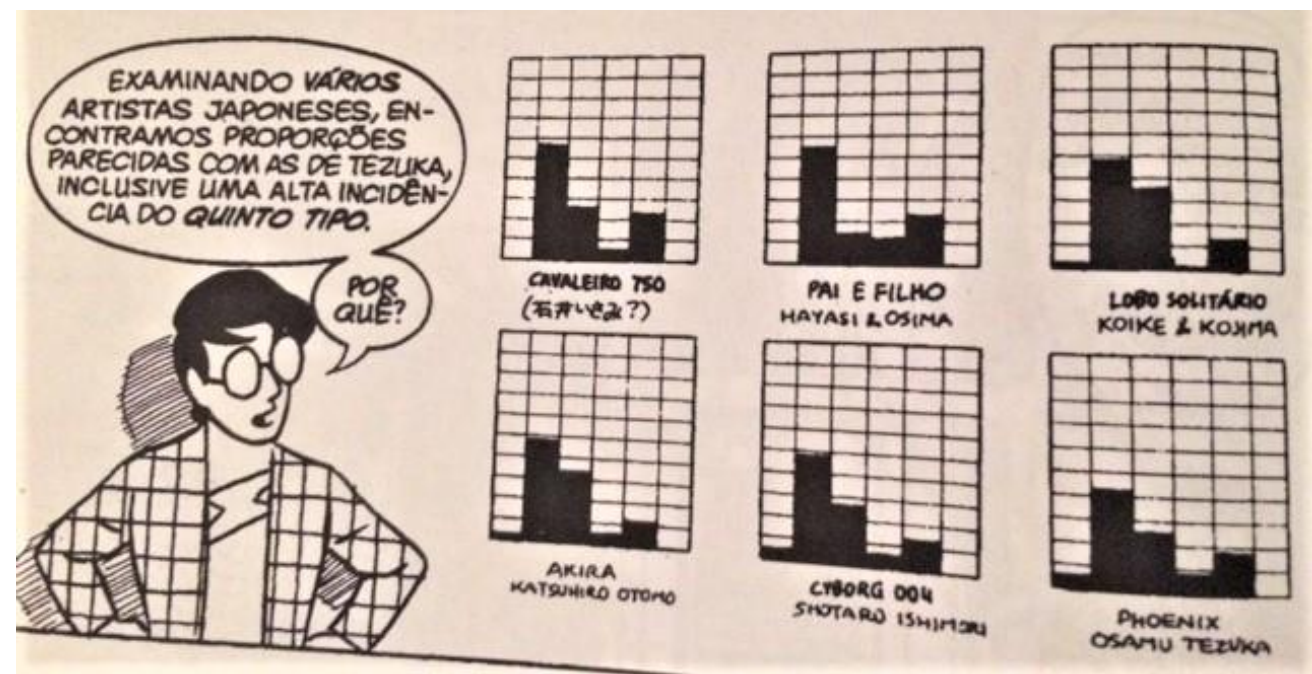

Figura 18 - Desvendando os quadrinhos, de Scott McCloud

A apropriação e atualização de uma estética do fragmento pela linguagem contemporânea dos quadrinhos traduz-se em experiências diversas de remediação de outras artes, como a música, as artes gráficas, o teatro, a pintura, entre outros. McCloud ressalta em diversos campo de expressão o que significou a valorização do não dito e não mostrado: 
NAS ARTES GRAFICAS, ISSO SIGNIFICOU UM GRANDE ENFOQUE NAS RELAFÖES ENTRE FIGLRA/FUNDO ENO "ESPAEO NEGATIVO".

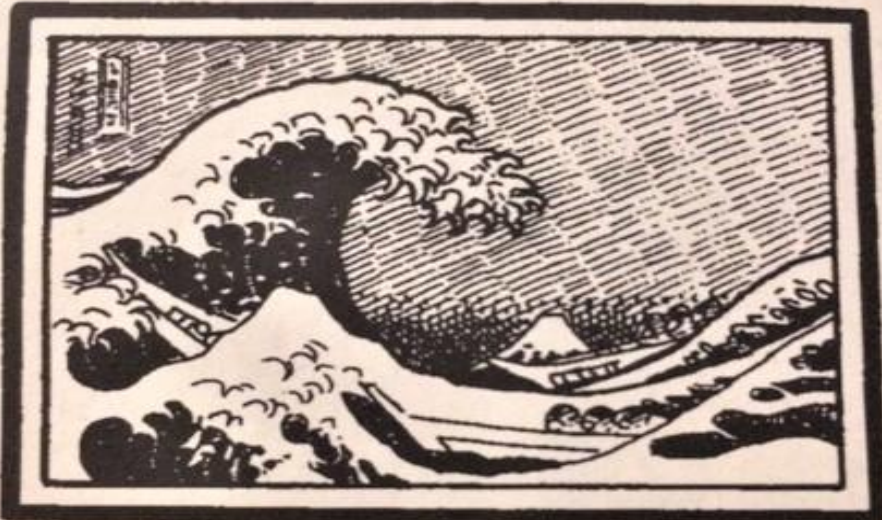

"O YAGALHÄO OE KANAOYWA", OE HOKUSAI (1829) CVIRE A FIGURA DE PONTA CAEECCA PRA VER A OUTRA ONDA DE ESPACO NECATIVO...O YIN EO YANE DA MATUREZA.)

Figura 19 - Desvendando os quadrinhos, de Scott McCloud

DE DEEUSSY E STRAVINSKY E COUNT QASIE, A MLUSICA OCIDENTAL INCORPO. ROU UMA FORTE CONSCIENCIA DO PODER DA FRAGMENTARTO E DOS INTERVALOS.

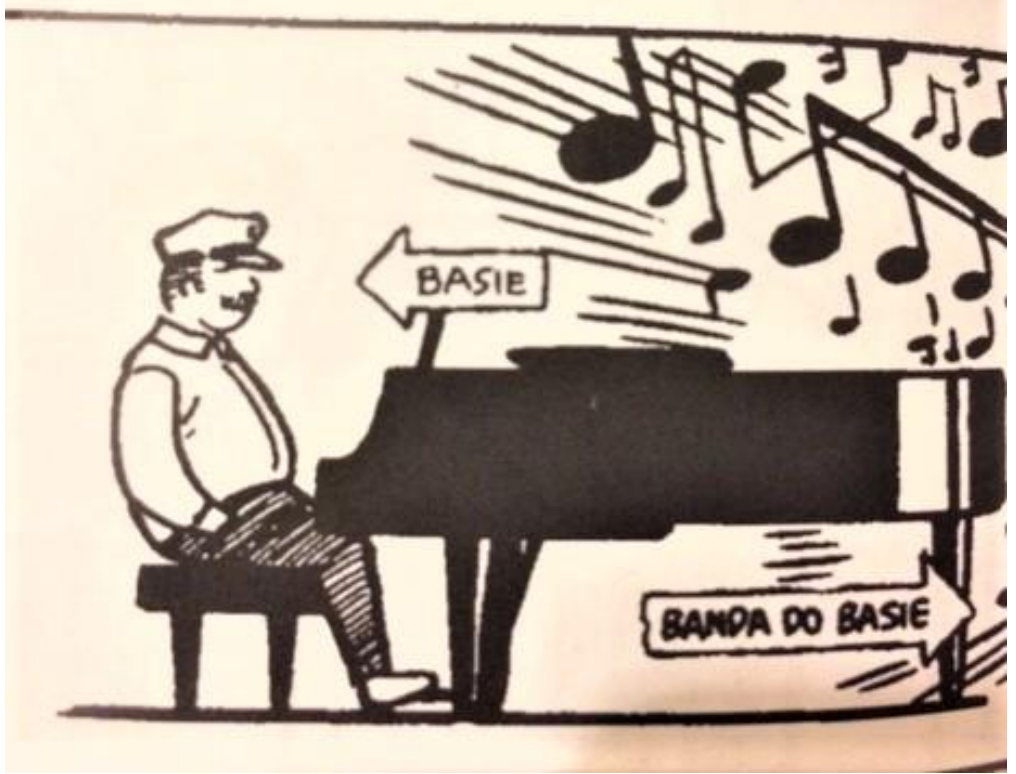

Figura 20 - Desvendando os quadrinhos, de Scott McCloud 


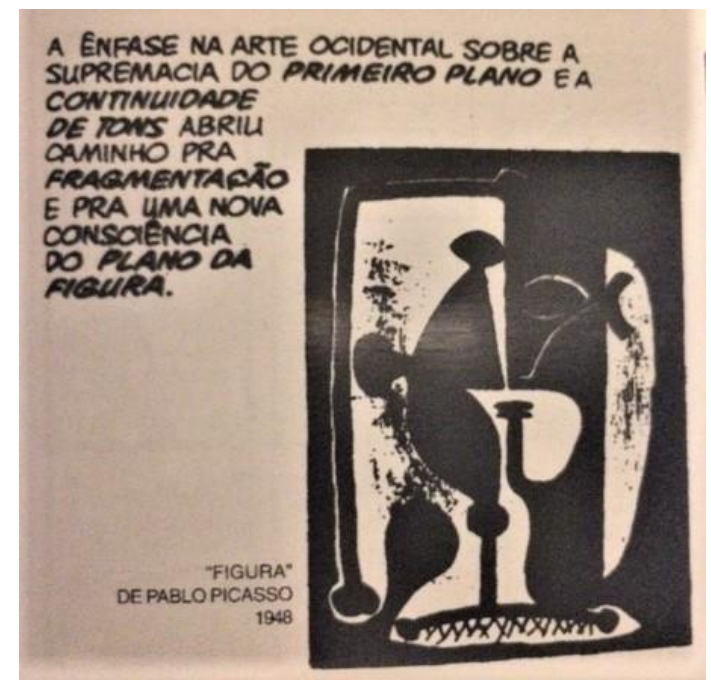

Figura 21 - Desvendando os quadrinhos, de Scott McCloud

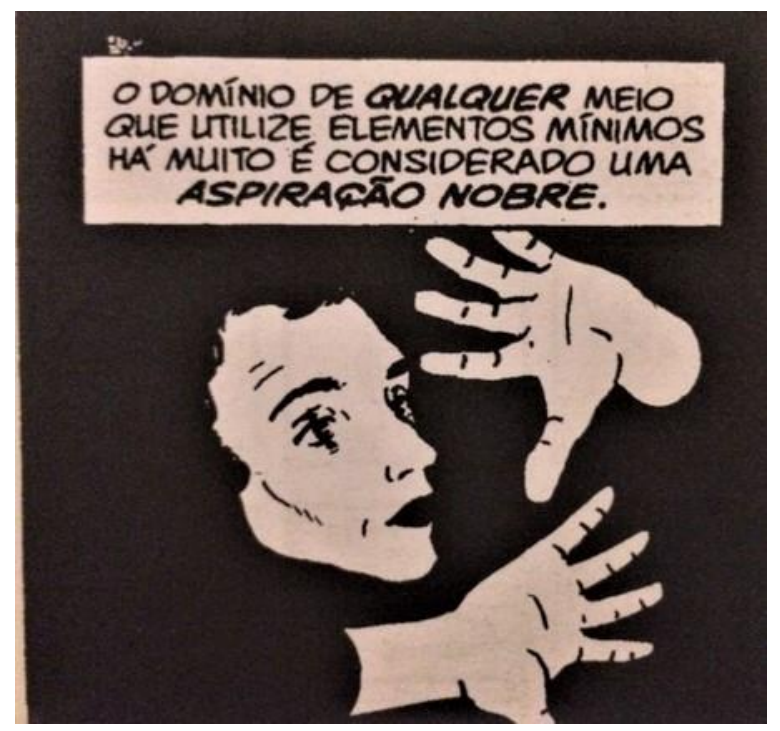

Figura 22 - Desvendando os quadrinhos, de Scott McCloud

Uma das maiores contribuições de Scott McCloud foi sem dúvida ter criado um conjunto de informações sistematizadas sobre os quadrinhos. Os quadros abaixo listam os seis tipos de transição em que, com alguma boa vontade, todas as sequencias em quadrinho, em alguma medida, se encaixam. A montagem nos quadrinhos, pensada como transição de um quadro a outro, segue portanto, genericamente falando, os modelos abaixo: 


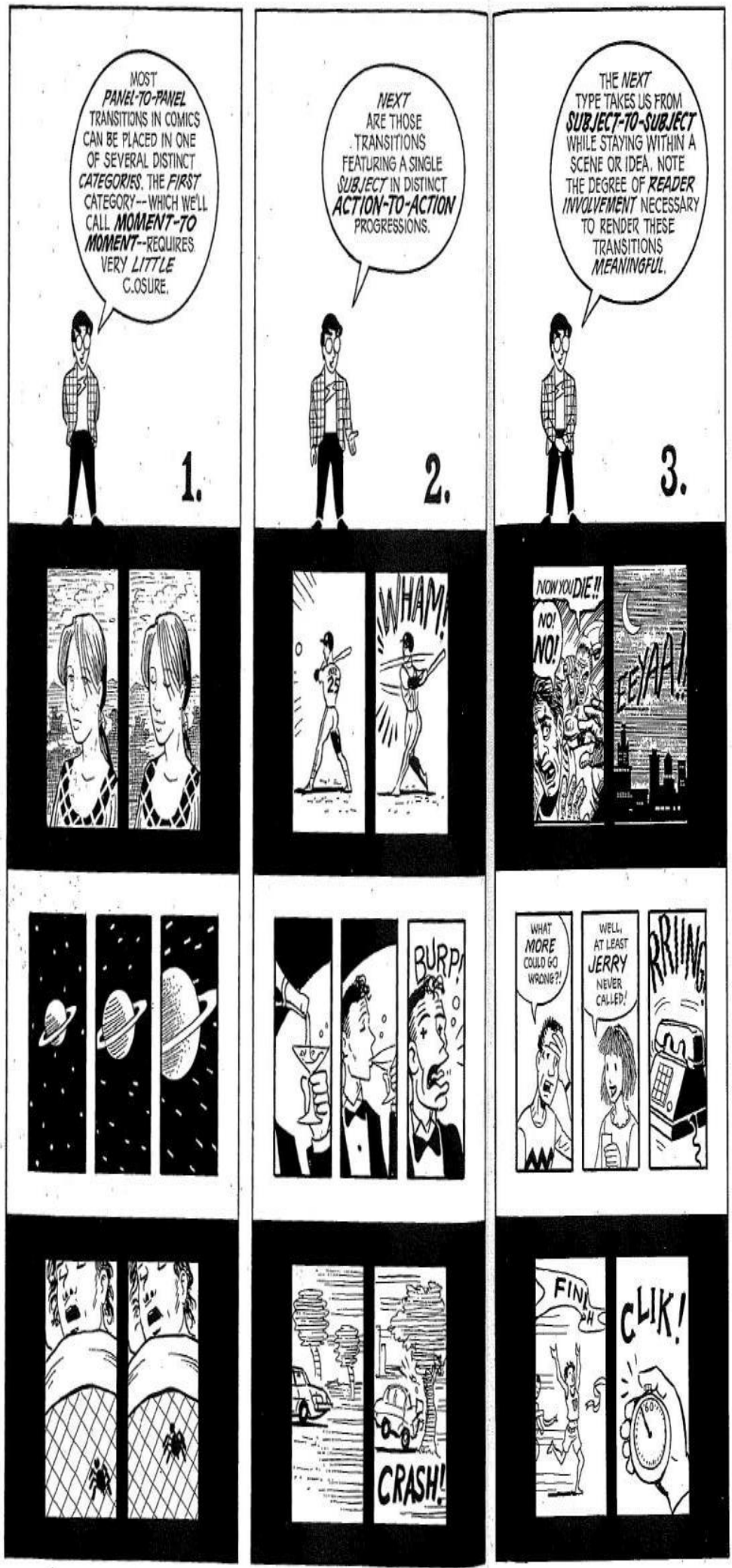

Figura 23 - Desvendando os quadrinhos, de Scott McCloud 

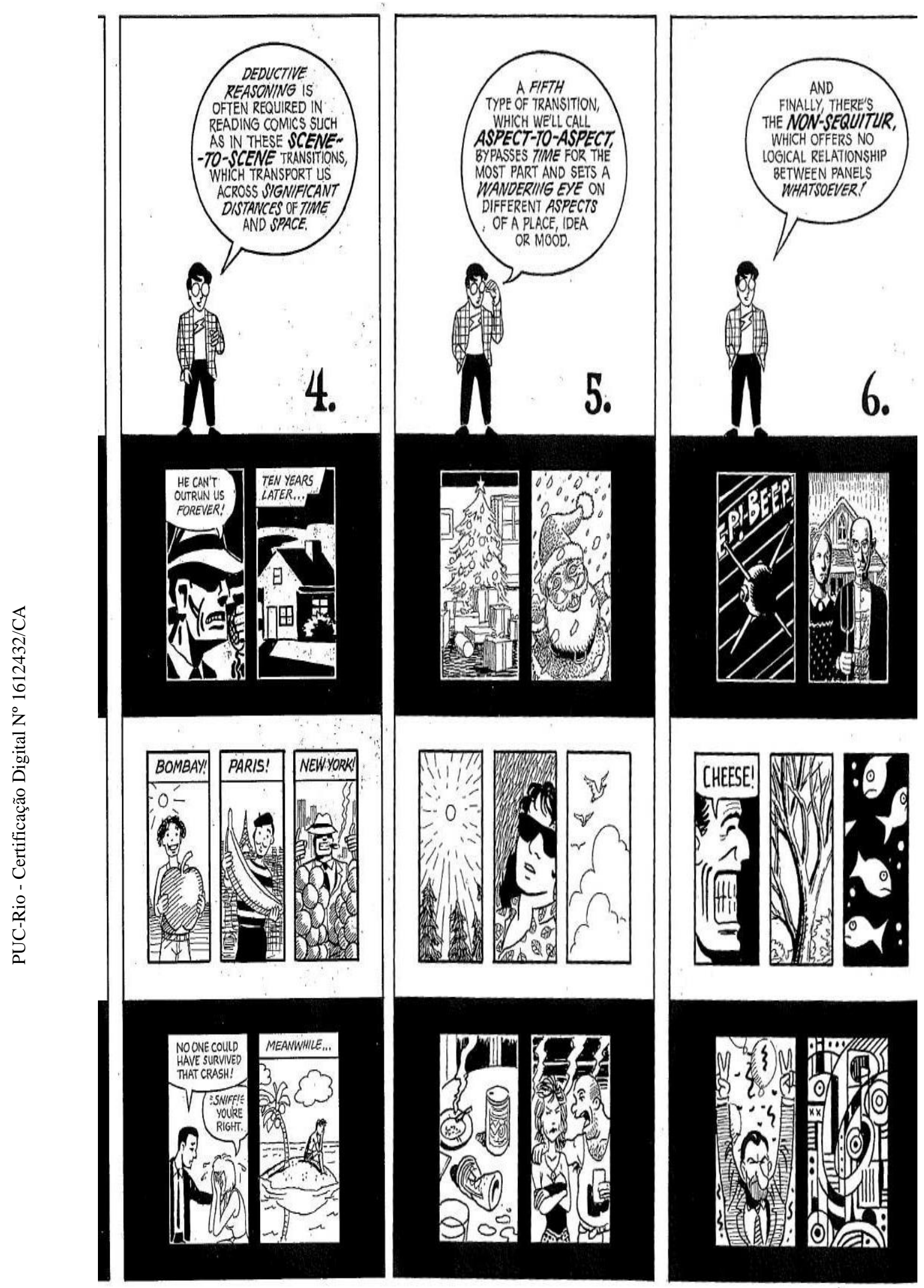

Figura 24 - Desvendando os quadrinhos, de Scott McCloud 
No Quadro 1, a imagem de uma mulher é mostrada em dois momentos, aparentemente muito próximos um do outro, McCloud afirma que a operação de montagem solicitada é mínima neste caso. Pouca coisa aconteceu. Seja como for, essa disposição de imagens em montagem não favorece a ideia de ação executada. Talvez por isso, seja pouco usada nos quadrinhos cujo compromisso com a aventura da história se mostre prioridade.

Contudo, a defesa de McCloud - de que, invariavelmente, a operação momento-a-momento demanda muito pouco de uma operação de montagem -, talvez possa ser problematizada, já que esse "pouco" ou "muito" demandado à imaginação pela montagem não pode ser quantificado a partir da relação entre dois quadros apenas, medido por uma projeção de tempo transcorrido, medido a partir do movimento, mas, sim, a partir do contexto em que se insere, incluindo às relações a que remete. Dispor os quadros dessa forma tende a apontar para uma relação de remediação por parte dos quadrinhos dos procedimentos do cinema, dispondo as imagens frame a frame para criar algum tipo de efeito, de imobilidade ou de curto intervalo de tempo.

O quadro 2 promove uma transição onde a passagem de tempo é maior e, com ela, também a curva da ação. Não à toa, esse tipo de operação é a mais usada entre os autores ocidentais. É o que diz McCloud depois de contabilizar e categorizar os tipos de associação quadro a quadro em diversos trabalhos. Uma pequena amostra, qualitativamente representativa, nos oferece uma lista com nomes tão heterogêneos como os de Jack Kirby (Quarteto Fantástico), Hergê (Tin Tin) Claremont \& Lee (X-Men), G Hernandez (Heartbreack soup), Doyle e Decarlo (Betty e Verônica), Gregory (Naughty Bits), Woodring (Frank in the river), Eisner (Contract with God), Spielgmann (Mauss), Barks (Pato Donald) e Tesuka. McCloud compara os quadros 1 e 2 dizendo que o 2 é mais sintético ao obter o mesmo resultado que o 1. Novamente, vale problematizar essa observação. Não se trata de eficiência simplesmente, trata-se, antes, do tipo de efeito que se deseja produzir. Se o ponto de vista de McCloud privilegia exclusivamente a ideia de ação, então, sim, a transição ação a ação é mais indicada. Mas se, ao contrário, a ideia é 
passar imobilidade ou duração de tempo, a transição "momento a momento", a transição 1 será mais eficiente.

$\mathrm{O}$ aspecto fragmentário das imagens aqui já se coloca de modo mais significativo nas transições dos quadros 3, 4 e 5. A transição "tema para tema" (quadro 3) enfatiza uma mudança no nível espacial que relaciona duas imagens pela ligação que estabelecem com o tema. Essa relação captura algumas vezes momentos simultâneos em espaços diferentes.

A transição cena a cena (quadro 4) também remedia o cinema e a literatura, ambas incorporam, em suas linguagens narrativas, a costura, a montagem a partir de pedaços heterogêneos, onde a continuidade é elipsada. Espaço e tempo enfrentam cortes significativos.

McCloud afirma que a maior incidência de transições dos quadrinhos está entre as ocorrências "ação a ação" e "cena a cena (quadros 2 e 4) ou seja, entre as transições que privilegiam a execução de uma ação

A transição "aspecto para aspecto" (quadro 5), na medida em que "supera o tempo" e estabelece "um olhar migratório", como é possível ler na ilustração acima, demanda da imaginação um tipo de transição que remete a uma percepção por vezes metonímica dos sentidos, por vezes fragmentada do todo, mostrando em detalhes recortes e ângulos. Essa transição sem dúvida é a que mais demanda à imaginação o esforço da liga. Quando há texto, este é quase sempre fragmentado e tende ao literário em suas conexões poéticas. Não é a por acaso que esse tipo de transição acontece em muito menor frequência que as transições mencionadas acima e normalmente nos quadrinhos de traço acentuadamente experimental.

A sexta transição nomeada non sequitur designa um tipo de relação que não se conecta realmente, e que por isso mesmo se permite ser qualquer coisa, inclusive uma continuidade. São, contudo, bastante raras nos quadrinhos. 
O pensamento que nos permite conceber as transições acima já se constituí em nossa relação com a pintura desde tempos remotos. É o que nos mostra a seguinte passagem de Manguel, em Lendo imagens:

Formalmente, as narrativas existem no tempo e as imagens, no espaço. Durante a Idade Média, um único painel pintado poderia representar uma sequência narrativa, incorporando o fluxo do tempo nos limites de um quadro espacial, como ocorre nas modernas histórias em quadrinho, com o mesmo personagem aparecendo várias vezes em uma paisagem unificadora, a medida que ele avança pelo enredo da pintura. Com o desenvolvimento da perspectiva, na renascença, os quadros passam a congelar um instante único, o momento da visão tal como percebida do ponto de vista do espectador. A narrativa então passou a ser transmitida por outros meios mediante simbolismo, poses dramáticas, alusões a literatura, títulos ou seja, por meio daquilo que o espectador por outras fontes sabia estar ocorrendo. (MANGUEL, 2001, p.24)

Disciplinas diversas, das científicas às humanas, estão de acordo que somos essencialmente seres de imagens, e que nosso pensamento opera com imagens mentais. 


\section{Quadrinhos e Intermidialidade}

\section{1}

\section{A intermidialidade como perspectiva metodológica}

Diferentemente das definições e perspectivas esboçadas na seção anterior, a perspectiva de quadrinhos que se busca adotar aqui, tanto a partir da discussão de textos teóricos quanto no experimento teórico, dá lugar de destaque às relações de intermidialidade estabelecidas com a pintura e a literatura. Trata-se de uma definição que busca identificar não os limites do objeto e a determinação de especificidades que se só se forjariam às custas de considerável arbitrariedade mas, sim, a perspectiva que nos deixe ver os quadrinhos em movimento de permanente construção e apropriação de outras artes e de outras mídias.

Para evitar ambiguidades em relação ao uso desses dois termos - arte e mídia - é preciso esclarecer que em determinados usos eles se equivalem, e em outros não. Toda arte inclui uma mídia, embora nem toda mídia envolva necessariamente uma intenção artística, ou seja, reflexiva, crítica.

Assim sendo, e dada a amplitude dos recortes da Intermidialidade, convém definir qual é o ângulo específico que se deseja tratar, situando, primeiramente, e de forma breve, o percurso que deu origem aos Estudos de Intermidialidade, e dentro desse campo, em uma segunda etapa, à proposta de uma arqueologia da intermidialidade.

O termo intermídia surge em 1966, no ensaio intitulado Intermedia, Something Else Newsletter, de Dick Higgins. Embora tenha uma pré-história extensa, ainda é considerado um conceito em processo, portanto, um eixo de pesquisa com uma abordagem relativamente "nova". Os antecedentes da intermidialidade perpassam conceitos como a dinâmica intertextual discutida por Julia Kristeva e os estudos interartes. A primeira corrente, mais voltada para a tradição literária, e a segunda para as formas de expressão consideradas como artes. Não é, contudo, um conceito "novo", mas que só começa a ser discutido de maneira mais efetiva no meio acadêmico a partir da década de 1980, quando se acirra a preocupação em compreender os procedimentos, estruturas e conceitos que integram as mídias e, consequentemente, esses processos em suas dimensões históricas e sociais (MÜLLER, 2012, apud COCA, 2013) 
Nas últimas cinco décadas, o alto e progressivo impacto das tecnologias de informação e comunicação favoreceu, em grande medida, a construção de novas perspectivas para os estudos das relações entre as artes, induzindo pesquisadores interessados neste tema a revisitar suas bases teóricas e a buscar novos conceitos para a sustentação de suas investigações. Percebeu-se a necessidade de incluir no radar dos estudos comparativos das artes também a questão indissociável das mídias.

João Maria Mendes (2001) oferece as referências etimológicas do termo, os quais remontam aos estudos aplicados de comunicação. Reconhece, no entanto, que seu uso transdisciplinar ampliou sobremaneira a designação inicial referente às práticas de comunicação desenvolvidas simultaneamente em diferentes mídias ou aos usos de meios e dispositivos comuns às diferentes mídias. Em verdade, arremata o autor, o que destaca a intermidialidade é trazer para a cena a materialidade dos objetos, visando

(...) proceder ao estudo dos diferentes níveis de materialidade implicados na constituição de objectos, sujeitos, instituições, comunidades, que só uma análise das relações pode evidenciar. Tal empresa exige a convergência de competências transdisciplinares, visto implicar o estudo dos corpus teóricos (sob o escalpelo de um novo aparelho conceptual necessário à passagem de uma lógica do ser a uma lógica da relação), uma perspectiva histórica (problema da constituição dos meios) e um enfoque experimental (problema da identificação das relações). A intermedialidade afirma-se, assim, não só como posição epistemológica (visando a instalação de realidades, mais do que as realidades já instaladas), mas também como plano de colaboração, por excelência, entre as disciplinas que os membros do Centre de Recherche sur l'Intermédialité (CRI) representam (história da arte, literatura comparada, comunicação, estudos literários, cinematográficos, audiovisuais, teatrais (MENDES, 2011, p. 8)

A definição de Mendes aponta simultaneamente para dois aspectos fundamentais da intermidialidade: o primeiro refere-se às suas múltiplas dimensões -, a epistemológica, a histórica e a prática. A outra, ao aspecto colaborativo e interdisciplinar da intermidialidade.

O desenvolvimento dos estudos sobre a intermidialidade inclui tendências que apareceram quase simultaneamente nos Estados Unidos e na Alemanha. Nos Estados Unidos, os chamados Estudos Interartes resultaram das Artes 
Comparativas, e tiveram origem na Literatura Comparada, especificamente nos Estudos de Literatura e Outras Artes. Em contrapartida, na Alemanha, simultaneamente ao desenvolvimento dos Estudos Interartes nos Estados Unidos, os Estudos de Intermidialidade emergiram como um campo autônomo de trabalho e pesquisa, abrangendo tanto as artes quanto as mídias, em um movimento fortemente acompanhado pelo Centro de pesquisas de intermidialidade de Montréal e por pesquisadores franceses e holandeses.

O teórico Claus Clüver chama a atenção para a imprecisão do termo Estudos Interartes, na medida em que se torna cada vez mais recorrente a inclusão de objetos que não são considerados arte no rol de interesses de seus pesquisadores. Com efeito, a necessidade de ampliar e debater questões que chegavam ao impasse no âmbito dos Estudos Interartes propiciou a construção do conceito de intermidialidade. O primeiro aspecto a gritar por reformulação nos Estudos Interartes foi o próprio conceito de arte. Discutir o que poderia ou não ser considerado arte revelou-se em boa medida estéril e incompatível com as novas experiências postas em curso, e, assim sendo, o que se colocava em questionamento eram os próprios objetos desses estudos.

Desde seus primórdios até a fase em que se falava de uma "iluminação mútua das artes" e também de "Artes Comparadas", este campo de estudos (Estudos Interartes) se ocupava de textos nos quais se reconhecia o status de "obras de arte", de acordo com as concepções de "arte" então dominantes. Mas, desde que Marcel Duchamp inventou o readymade, tornou-se cada vez mais difícil diferenciar a "arte" da "não-arte". Além disso, reconheceu-se que também textos que não pertencem às artes no sentido mais restrito do termo (como, por exemplo, a música popular) podiam ser objetos de estudos promissores. E, finalmente, considerou-se que a investigação de textos decididamente não recebidos como artísticos - seja por si mesmo, seja em comparação com "obras de arte" - poderia conduzir a conhecimentos importantes nesse campo. Quanto menos os Estudos Interartes se ocupam de questões da forma e da estética tradicional, tanto mais insignificantes se tornam essas diferenciações. O reconhecimento, aliás, de que as diferenciações se baseiam em construtos motivados ideologicamente, ao invés de qualidades ontologicamente essenciais, fortaleceu a postura de alguns pesquisadores no sentido de falar de "obras de arte" apenas em determinados contextos, totalmente conscientes das implicações do termo. Por conseguinte, o rótulo "Estudos Interartes" tornou-se cada vez mais impreciso e, assim, insatisfatório, tanto em relação aos textos tratados quanto às formas e gêneros textuais. (CLUVER, 2006, p.18) 
$\mathrm{O}$ conceito de intermidialidade tem, portanto, como pressuposto a ampliação de interesses até então restritos à literatura, pintura, música, dança, artes plásticas cinema, teatro e arquitetura, e o intuito de agregar também outras mídias e seus textos. A substituição do que se assumia até então como "Estudos interartes" por "Estudos de intermidialidade" tornou-se um tema de debate. Há pelo menos duas passagens dos textos de Claus Cluver e João Maria Mendes que apontam nessa direção:

Assim, não apenas por razões de intraduzibilidade para línguas como o alemão (este, causa dificuldades consideráveis num discurso internacional), mas antes, ainda, devido à insuficiência da designação usada até agora, parece oportuno buscar uma denominação mais adequada para o conceito geral, que abranja todo o campo de estudo. A combinação de "artes e mídias", com a qual já nos deparamos, bem como o termo "intermidialidade", já corrente no âmbito científico alemão, sugere a escolha deste ou de outro nome bem semelhante para o uso internacional. Intermidialidade diz respeito não só àquilo que nós designamos ainda amplamente como "artes" (Música, Literatura, Dança, Pintura e demais Artes Plásticas, Arquitetura, bem como formas mistas, como Ópera, Teatro e Cinema), mas também às "mídias" e seus textos, já costumeiramente assim designadas na maioria das línguas e culturas ocidentais. Portanto, ao lado das mídias impressas, como a imprensa, figuram (aqui também) o cinema e, além dele, a televisão, o rádio, o vídeo, bem como as várias mídias eletrônicas e digitais surgidas mais recentemente". (CLÜVER, 2006, p. 18)

Mendes cita Jürgen E. Müller (2006) para referir-se a um "subtil deslizamento do intermedial para o intermediático", e, aí, localizar a gênese da ideia de intermidialidade que desponta na segunda metade do século $\mathrm{XX}$ :

O Müller de 2006 pretende evitar a confusão entre os domínios da intermedialidade e os da interartialidade (noção emergente dos estudos interartes), porque, apesar do forte recobrimento parcial dos dois termos, - a intermedialidade opera num domínio que inclui os factores sociais, tecnológicos e mediáticos, enquanto a interartialidade se limita à reconstrução das interacções entre as artes e os procedimentos artísticos, inscrevendo-se numa tradição sobretudo poetológica. Müller espera que a intermedialidade assuma, apesar da sua vocação releitora e reescrevente, uma postura menos invasora, menos intrusiva e menos imperialista do que as adquiridas, nos anos 70 do séc. XX, pela semiótica e pela teoria do texto (MENDES, 2011, p. 11-12)

A intermidialidade, reforça-se aqui, propõe a consideração da materialidade, diferenciando-se, do ponto de vista epistemológico, dos estudos comparativos que consideram a relação entre as artes com seu foco no plano das discussões estéticas. Ainda que haja a problematização de certos pressupostos dos estudos comparativos 
entre as artes é importante ressaltar que isso não significa que a intermidialidade tenha trazido a inviabilidade destes estudos. Significa, antes, e sobretudo, que as indagações que motivam boa parte dos estudos já não giram em torno de uma ideia de especificidade estética (tampouco material) das artes. A pergunta "o que é a literatura?" ou "literatura é arte?", por exemplo, deixa de fazer sentido e, em seu lugar, novas indagações motivam-se pelo desejo de compreender os efeitos que ela é capaz de produzir. Walter Moser (1998), em texto que analisa os reposicionamentos dos Estudos Literários em razão dos temas que emergem dos Estudos Culturais, afirma a resiliência e continuidade dos Estudos Literários frente aos questionamentos que lhes desafiam.

A vasta tradição dos estudos interartes nas instituições anglófonas, esclarece João Maria Mendes (2011), permitiu que aí se enraizassem os conteúdos das intermidialidades, autonomizando-se como disciplina gradativamente, a partir do desenvolvimento das mídias eletrônicas e digitais no domínio das artes e da comunicação. Assim, fortaleceu-se a interdisciplinaridade com áreas de estudo como os estudos literários, os estudos de cinema, sociologia e história das artes entre outras.

A reconfiguração das mídias a partir de sua forte presença nas artes trouxe a reescrita de sua história à luz da intermidialidade, tornando apropriado o uso do termo "artes intermediais", que, segundo Mendes, são "aquelas que mais deliberadamente praticaram e praticam hibridações (ou hibridizações) e remediações na geração de novas obras” (MENDES, 2011, p. 13).

A expansão do conceito de intermidialidade, apoiado na materialidade das artes, ilumina ainda uma dimensão fundamental da intermidialidade que diz respeito à sua proposta epistemológica:

a intermedialidade analisa em especial as passagens, os lugares de cruzamento e de interacção entre as artes e o campo (digitalizado) dos media, embora sem enjeitar a herança cultural e artística de todas as experiências interartes anteriores à digitalização: se a enjeitasse, seria um campo de estudos amnésico, contradição axial, sobretudo se atendermos à relevância dos enfoques historiográficos a que tem dado origem, e que se contam entre as principais orientações aplicadas da intermedialidade. (MENDES, 2011, p. 12) 
Eleger o que seja específico de uma arte equivaleria, nesse sentido, a imaginar a possibilidade de sua origem espontânea e impermeável a tudo o que lhe preexistiu. $\mathrm{O}$ interesse pela relação entre as artes em perspectiva arqueológica e o contínuo movimento de remediação de uma arte por outra afirmam por premissa a ideia de que sendo a arte constituída por uma ou mais mídias, não há como pensar a arte a partir da ideia de uma origem espontânea e impermeável a tudo o que lhe preexistiu.

A prudência tem levado a uma compreensão —aberta da intermedialidade como work in progress, que não tente encerrá-la numa definição ontológica e se mantenha atenta ao conjunto de processos tecnológicos intermediais entendidos - em devir. Ao mesmo tempo, pretende-se, com este gesto prudencial, não reduzir a intermedialidade às suas componentes ou à análise daquilo de que é feita - o que lhe roubaria o carácter de objecto de estudo autónomo e dinâmico (MENDES, 2011, p. 8)

O desejo de superar os questionamentos de ordem ontológica, em contrapartida, tem feito expandir não apenas o escopo de objetos considerados, mas também as preocupações epistemológicas de muitas disciplinas, fortalecendo, além disso, o corte transversal da interdisciplinaridade.

Se, por exemplo, definimos a intermedialidade em termos de encontro e de relação entre duas ou mais práticas significantes, o ponto de partida é ainda o da preexistência e da identidade das práticas separadas, e o ponto de chegada exprime, por seu turno, os resultados desse encontro: a identificação dos momentos híbridos, a análise dos mistos, etc. O fluxo é analisado, portanto imobilizado e decomposto. [Ora], a intermedialidade está mais do lado do movimento e do devir, lugar de um saber que não será o do ser. Ou então é o lugar de um pensamento do ser já não entendido como continuidade e unidade, mas como diferença e intervalo. (MARINELLO, 2000 apud MENDES, 2011)

A intermidialidade, portanto, nos oferta a possibilidade de olhar para a arte sem procurar imobilizá-la em um conjunto de procedimentos capaz de revelar sua especificidade ou seus aspectos ontológicos, seu "ponto de partida" ou de chegada. Seu interesse recai sobre o fluxo, o movimento, sobre os espaços de intervalo, e, portanto, sobre a composição e a montagem que permitem a análise de momentos híbridos que resultam dos diferentes níveis de materialidade implicados nos objetos. 
A tentativa de responder a argumentos ora ontológicos ora políticos (por exemplo, a acusação da natureza elitista dos objetos literários estudados) resultou em uma série de reformas desse campo disciplinar, o que na visão de Moser deve ser positivamente contabilizado por ter permitido a instabilidade e dinamismo dos Estudos Literários Sobre essas reformas, a que Moser chama de "paliativos", vale ainda ressaltar:

\begin{abstract}
Além disso, pode-se afirmar que (os paliativos) contribuíram de maneira decisiva para provocar mudanças importantes na produção e na organização dos conhecimentos em ciências humanas. Do mesmo modo, participaram e realizaram estratégias interdisciplinares em ciências humanas. Sem certos desenvolvimentos (refiro-me, especialmente, ao desconstrutivismo que, procedente da filosofia, foi difundido, principalmente pelos departamentos de literatura) no núcleo do EL, a mudança de rumo linguística, tomada genericamente pelas ciências humanas e que se estendeu até as ciências sociais, não teria tido o impacto que conhecemos." (MOSER, 1998, p. 65)
\end{abstract}

Reconhecer que a literatura não é um campo de fronteiras bem delimitadas. O que não significa declarar a inviabilidade dos estudos literários evidentemente. Significa, antes, e sobretudo, que as indagações que motivam boa parte dos estudos já não giram em torno de uma ideia de especificidade estética e material das artes. A pergunta "o que é a literatura?" deixa de fazer sentido e, em seu lugar, as novas indagações motivam-se pelo desejo de compreender os efeitos que ela é capaz de produzir. Walter Moser (1998), em texto que analisa os reposicionamentos dos Estudos Literários em razão dos temas que emergem dos Estudos Culturais, afirma a resiliência e continuidade dos Estudos Literários frente aos questionamentos que lhes desafiam:

$\mathrm{O}$ ataque mais radical contra uma disciplina consiste em provar a inexistência de seu objeto. De fato, o argumento ontológico põe fim ao debate: afirmar que não há respostas que satisfaça as questões "o que é literatura", "qual é a especificidade do texto literário?", mostrar o estatuto fantasmagórico da "literariedade", são gestos que equivalem a uma condenação sem recursos dos estudos literários. (MOSER, 1998, p. 16)

Vale ainda acrescentar, como chama a atenção João Maria Mendes, que crises geram questionamentos mas não necessariamente a substituição de uma disciplina por outra: 
Naturalmente que, mesmo quando inscreveram a intermedialidade no seu vocabulário e passaram a reconhecê-la como área autónoma de estudos, as instituições de ensino superior não abdicaram dos estudos comparatistas e interartes, que precederam a generalização da ideia intermedial e subsistem e subsistirão, em muitas delas, como áreas ou ramos estabilizados e assentes numa tradição próxima dos Cultural Studies. Depressa, porém, a intermedialidade artística (a das artes plásticas e das artes visuais) passou a necessitar da proximidade de anteriores interdisciplinaridades e intertextualidades, dos cruzamentos e convergências das práticas daquele universo mais antigo e mais vasto - o das literaturas, das artes da cena e do ecrã (...). (MENDES, 2011, p. 13)

O reposicionamento dos Estudos Literários em reação às críticas foi além do recrudescimento de seus antigos posicionamentos, o que preveniu este campo de sucumbir às propostas de sua substituição pelos Estudos Culturais, como chegaram a propor alguns autores. O que parece interessante destacar aqui é o horizonte de diálogo possível entre os Estudos Literários e os Estudos Culturais, horizonte este no qual uma arqueologia da intermidialidade pensada para os quadrinhos poderia se inserir.

$\mathrm{Na}$ seção seguinte, busca-se compreender em que consiste a proposta de uma arqueologia da intermidialidade, procurando as implicações que o termo "arqueologia" traz para o estudo da intermidialidade. Nessa direção, o intuito é de verificar em que medida é possível pensar os quadrinhos a partir desse pensamento arqueológico.

\section{2}

\section{O prisma de uma arqueologia da intermidialidade}

Walter Moser em seu estudo “A relação entre as artes: por uma arqueologia da intermidialidade" parte do seguinte pressuposto:

a relação entre as artes, por implicação, comporta sempre, também, questões intermidiáticas, mesmo que estas não sejam assim explicitadas, considerando-se que toda arte inclui a 'intermidialidade'. (MOSER, 2006, p. 42)

Dois pontos revelam-se fundamentais no foco de Moser. O primeiro é que ele considera a materialidade do objeto e sustenta que a relação entre as artes é 
também sempre uma relação entre mídias - e o inverso não é necessariamente verdadeiro, como já foi apontado aqui (pág.35). Outro ponto importante que o destaca entre outras perspectivas dentro dos Estudos de Intermidialidade é o posicionamento de seu interesse na relação entre as mídias, na veiculação de uma mídia por outra, e não necessariamente no objeto que resulta dessa relação. Daí resulta sua apropriação do conceito de remediação, elaborado recentemente por Bolter e Grusin. A remediação torna-se central em sua proposta arqueológica das mídias e refere-se ao conjunto de interações possíveis entre as artes. Importante mencionar que a interação pode estar presente na produção (a obra) ou nos processos de recepção e conhecimento. Tudo isso evidencia seu interesse no constante movimento de mídias que recriam umas às outras.

Moser adverte que, não obstante a centralidade que a relação entre pintura e poesia vem ocupando entre as análises que pensam a relação entre as artes, sua proposta é pensar também outros campos em que essa relação se dá de forma significativa. Argumenta que no romantismo, as relações entre música e literatura ganharam certo protagonismo no debate sobre as relações entre as artes. Moser vê aí uma virada fonocentrista, a pressuposição de uma "intermidialidade fundamental entre mídia sonora e mídia escritural/impressa”. (MOSER, 2006, p.50).

A relação entre pintura e poesia predominou, por muito tempo, nos debates sobre a relação entre as artes. Moser elenca alguns dos principais topoi dessa relação: a Arte Poética de Horácio e seu ut pictura poesis, as especulações de Simônides, relatadas por Plutarco, e também o Paragone de Leonardo, na Itália renascentista. Sua intenção é caracterizar um campo de interações múltiplas - e, algumas vezes, conflituosas - onde havia basicamente duas relações implicadas: a primeira, uma relação de igualdade e reciprocidade, uma relação de irmandade (sister arts) que resulta da compreensão de um pertencimento comum a uma estética da imitação que se tornaria o chamado tertium comparationis (MOSER, 2006, p. 44); já a outra relação é de disputa, interessada em definir a precedência de uma arte sobre a outra, e em entender como se promovem uma a modelo da outra. 
Em 1766, o tratado de Lessing, Laocoonte - oder: Über die Grenzen der Malerei und Poesie, propõe traçar fronteiras claras entre pintura e poesia, e, com base em descrições minuciosas, legisla e estabelece um topos da relação poesia e pintura. Para Moser, o que Lessing destaca marca uma diferença importante nesse debate: as diferenças que caracterizam as artes não estariam, na obra de Lessing, no plano do objetivo estético, uma vez que, baseando-se na estética da imitação, ambas podem lograr os mesmos efeitos. O que revela e assegura as diferenças são aspectos relacionados à materialidade das artes (aos procedimentos, meios e objetos). Em outras palavras, "Lessing diferencia poesia e pintura tomando como base sua midialidade, e não sua estética" (MOSER, 2006, p. 45).

O que Moser deduz daí é que Lessing introduz de forma sistemática uma argumentação calcada na diferença entre mídia e arte, ao estabelecer que toda arte depende de uma midialidade específica. As incursões de uma arte pela outra, vistas por Lessing como transgressões das leis, são valorizadas como "passes de mágica", "atos de prestidigitação". Apesar de sua ambição doutrinadora e legisladora, Lessing tem, entretanto - argumenta Moser -, a honestidade e a generosidade de reconhecer a expressividade ímpar atingida por estas transgressões. O exemplo que ele dá para a incursão do pintor no território do poeta é

(...) a maneira como Rafael representa as dobras das vestimentas sobre um corpo em movimento: Rafael descola o movimento do tecido em relação ao do corpo, o que lhe permite representar dois momentos diferentes e sucessivos dentro do totum simul pictural. (...) Apesar disso, quem ousaria recriminar o artista por tirar vantagem de mostrar simultaneamente esses dois momentos? Pelo contrário, quem não o elogiaria por ter tido o engenho e a sensibilidade de cometer este pequeno erro para atingir uma maior perfeição da expressão? (MOSER, 2006, p. 46)

Lessing, citado por Moser (acima), expõe por meio de posição rígida e doutrinária como a experimentação que rompe regras ocupa um lugar controverso entre o erro e o feito admirável, à frente do seu tempo.

O exemplo inverso, aquele que ilustra a incursão do poeta no território do pintor, é o do célebre escudo de Aquiles, na obra de Homero:

Um escudo, enquanto objeto a ser representado, responde, em princípio, exatamente à configuração de um objeto da pintura: é um corpo cujas partes são espacialmente 
justapostas e percebíveis em sua totalidade por meio de um único olhar. A artimanha do poeta consiste em uma tradução desse objeto (corpo) em uma ação, e faz isso de certa forma como uma operação preliminar à sua representação poética. Homero não descreverá o escudo, mas contará o processo de fabricação deste por Vulcão. (MOSER, 2006, p. 46).

Para Moser, Lessing aponta para um aspecto que viria a ser fundante das questões da Intermidialidade quando reconhece as condições possíveis em que uma arte, mesmo circunscrita às especificidades da mídia que lhe dá materialidade, reapresenta, à sua maneira, os expedientes de outra arte, de outra mídia. Assim, esclarece:

Primeiro, o pintor só pode, em princípio, representar um momento único dentro do desenvolvimento de uma ação, mas tende a transcender essa coação escolhendo como objeto a ser representado o que Lessing denomina um momento "fértil" (fruchtbar) ou "conciso e denso" (prägnant). Esse momento seria escolhido de maneira a obrigar o espectador a estendê-lo em sua imaginação em direção ao passado ou ao futuro; ele contém, portanto, uma temporalidade potencialmente mais vasta que o momento representado picturalmente. (MOSER, 2006, p. 46)

Moser analisa o caso romântico por ver nele uma revolução estética. Para ele, a chamada "encruzilhada" marca uma mudança de paradigma sem precedentes:

De uma teoria estética baseada na imitação de um mundo já dado, que é ainda o denominador comum, ou o tertium comparationis, entre pintura e poesia na obra de Lessing, passa-se a uma teoria estética baseada na capacidade de criar novos mundos imaginários. Da mimesis passa-se à poïesis, reativando o conteúdo semântico do verbo grego poïein, que significa "fazer", "fabricar". (MOSER, 2006, p. 47)

No início do século XIX, a valorização do poder criador desloca, do objeto para o artista, o ponto de atenção da teoria da arte, tornando-a interessada em novos horizontes de relações entre as artes.

Em sua posição de arte-modelo, a pintura cede seu lugar para a música: "A relação entre 'as artes irmãs', poesia e pintura, sofreu uma mudança básica no início do século XIX, uma mudança em que a poesia abandonou suas alianças com a pintura e descobriu novas analogias na música." O modelo artístico não é mais uma arte que imita e cópia, mas uma arte não-representativa, da qual prestamos conta não em termos de verdade e adequação a um objeto a ser representado, mas em termos de energética emotiva. (MOSER, 2006, p. 47)

O primeiro exemplo oferecido por Moser para falar do contexto acima é o do pintor e poeta William Blake (1757-1827). Moser procura argumentar que Blake investe 
em uma atitude "antipicturalista", e, embora à primeira vista pareça expressar um certo fonocentrismo, o que de fato ele expressa é uma valorização da tipografia como mídia completa, independente da fala.

Como ele conseguiu manifestar esta coisa antigramatológica que é uma presença plenária na escrita? Ora: graças a uma relação intermidiática, em um desvio por outra mídia que não a escrita. Ele confia à imagem (gravada ou pintada) a representação da midialidade da escrita. (MOSER, 2006, p. 47)

A poesia de Blake procura dar conta de uma visualização pictural, constituindo uma verdadeira linguagem visual: Ao integrar palavra e imagem, o verbal e o visual, Blake cria uma verdadeira linguagem visual que nos fornecerá um caso particularmente interessante para observar a interação entre as artes e as mídias. (MOSER, 2006, p. 47)

Vale ressaltar, contudo, como adverte Moser, que essa linguagem visual esteve presente em manifestações anteriores:

É preciso situar essa linguagem visual dentro da longa tradição de uma vertente do picture-poem que remonta até a Antiguidade, conhece realizações particularmente interessantes na poesia experimental da época barroca e encontra um avatar nos caligramas e na poesia concreta do século XX. (MOSER, 2006, p. 48)

A história ilustrada de Blake nos mostra que o escrito, como "autoridade estabelecida da lei patriarcal" e o escrito como "processualidade presente e eficaz" equilibram-se, sem permitir que se diga se a imagem precede a palavra ou o contrário. 


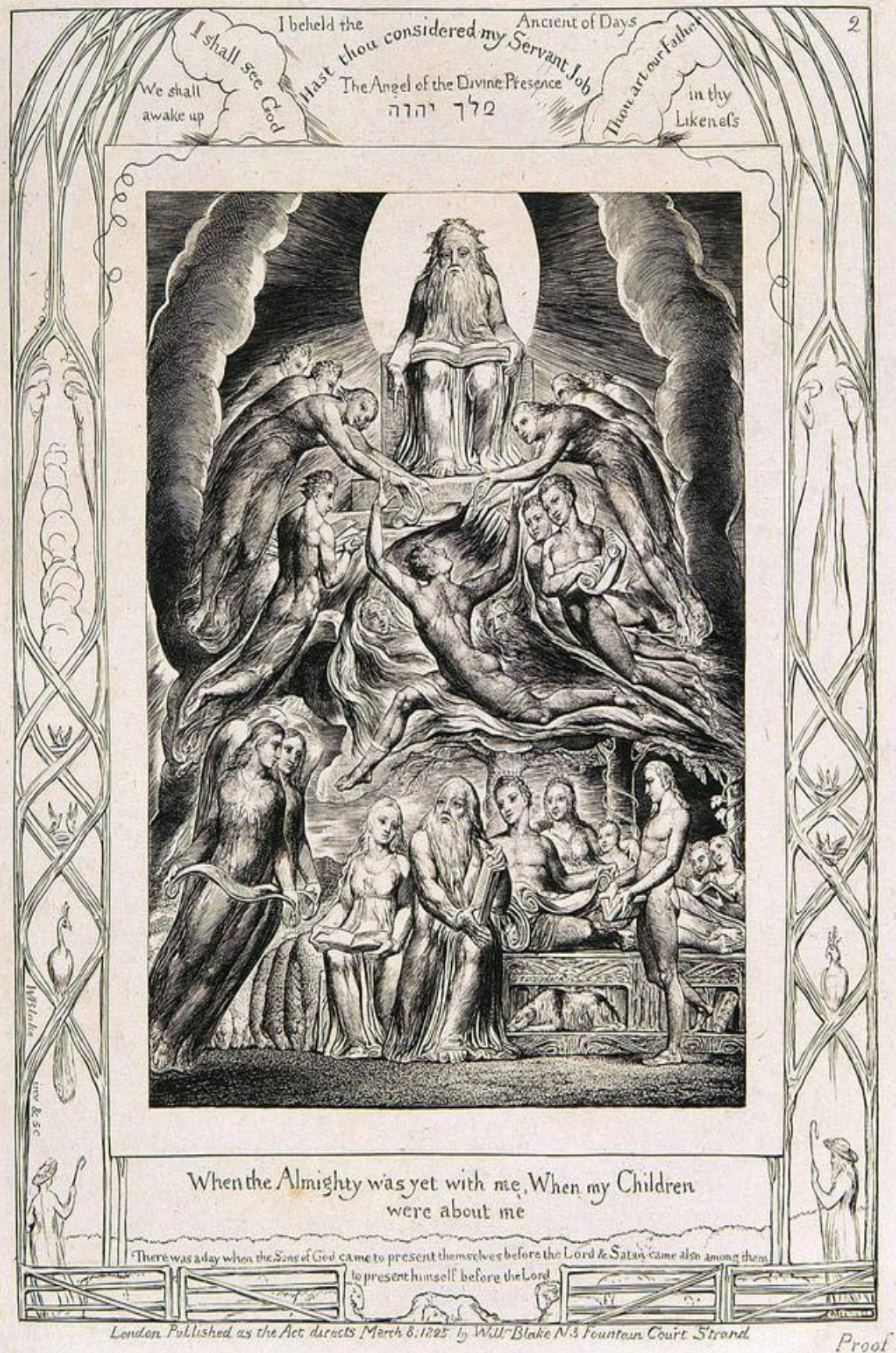

Figura 25 - The book of job, de William Blake, 1825.

Outro exemplo emblemático trabalhado por Walter Moser para pensar a relação entre música e literatura é a obra do compositor, pianista e maestro Ernst Theodor Wilhelm Amadeus Hoffmann (1776-1822). Para Moser, "Hoffmann 
prepara a cena para a visualização corporal das performances musicais" e dá um passo adiante em relação a outros artistas românticos ao procurar a "presença originária plena" não na voz, mas, sim, na música instrumental - não em uma mídia linguística, mas fora da linguagem.

Hoffmann não compara e nem opõe duas modalidades de realização da mídia linguagem (oral e escrita), mas, sim, a mídia escrita (literatura) à mídia sonora mais assemântica da música instrumental. (...) O texto insiste na intensidade energética do que vai se expressar sobre esse rosto torturado, servindo-se de um vocabulário que se condensa em uma verdadeira isotopia energética: "viva", "furor", "inflamar", "fogo", "brilham", "delira", "sacudir convulsivamente". Estamos longe, aqui, de uma estética da imitação do mundo. A originalidade do procedimento de Hoffmann, referente ao mesmo tempo às relações entre as artes e entre as mídias, consiste em transpor essa energética interior de modo intermidiático em uma visualização corporal - tudo isso, não podemos nos esquecer, é confiado como objeto de representação à obra literária, objeto que lhe é acessível graças ao semantismo de sua mídia. (MOSER, 2006, p. 49)

A referência, na literatura de Hoffman, à intermidialidade constitutiva da música instrumental é clara. O que Hoffman faz é "escrever (sobre) a música”, ou seja, é partir do texto escrito para "representar e colocar em cena aquilo que é colocado como totalmente outro, pois dotado, por definição, de uma superioridade ôntica incontestável” (MOSER, 2006, p. 51). Isso posto, cabe-nos seguir com Moser e perguntar o que Blake e Hoffmann compartilham como exemplos.

O que Blake e Hoffmann têm em comum é, antes de tudo, sua grande distância em relação à legislação de Lessing. Caso se aceitasse a lógica do Laokoon, só se encontraria, na obra dos dois poetas românticos, a transgressão e subversão da codificação das artes. Mais, ainda: sua poética e estética da criação in actu e da performance viva e energética não respeitaria mais a codificação das artes por Lessing, mas pareceria que sua articulação só poderia ser feita ao se criar um local de interação complexa entre ao menos duas artes. (MOSER, 2006, p. 52)

Ao lançar mão dos exemplos de Blake e Hoffmann, Moser quer mostrar que a midialidade de uma arte tende a se tornar transparente, a se apagar; e a melhor forma de percebê-la é observando-a na relação com outra mídia.

Essa escrita literária sobre a música só consegue, portanto, sustentar sua aposta impossível (captar, na prática de uma arte inferior, a superioridade de outra arte), com a condição de encenar sua auto-anulação midiática, isto é, encenar ficcionalmente a retirada de impedimentos que lhe impõe sua própria midialidade: a música só pode ser afirmada como performance pura sob a condição de negar sua 
realização enquanto escrita ou enquanto impresso. Contudo, essas duas variantes da escrita não são simplesmente ausentes ou inexistentes; em um gesto duplo, elas são evocadas/revogadas, realizadas/apagadas, afirmadas/ negadas. (MOSER, 2006, p. 52)

Outros dois exemplos escolhidos por Moser para estruturar a teoria da remediação são os filmes Caravaggio (1986), de Derek Jarman, e Passion de Jean Luc Godard. No primeiro, a vida e a produção do pintor Michelangelo são mostrados no intuito de revelar a midialidade da pintura, a qual tende a se tornar transparente. No segundo,

De maneira um pouco apressada, poder-se-ia dizer que Godard faz um trabalho sobre a mídia filme em Passion que é análogo ao que Jarman faz sobre a mídia pintura em Caravaggio. A relação entre as artes que está subjacente nos dois filmes é, portanto, utilizada para tornar visível e reconhecível a midialidade de uma arte diferente em cada um dos dois filmes. Em Jarman, somos colocados dentro de um ateliê de pintura e assistimos à produção de um quadro: na relação pintura-cinema, quadro-filme, a relação entre as artes é usada para captar a midialidade da pintura. Em Godard, estamos dentro de um estúdio cinematográfico e assistimos à produção de um filme: na relação entre pintura e cinema, quadro-filme, essa relação entre as artes (mais, ainda, a relação entre arte e mídia) é utilizada para captar a midialidade do filme. (MOSER, 2006, p. 63)

O aperfeiçoamento da reprodução artística no século XIX, provocou mudanças sem precedentes nos modos de produção artística, provocando em boa medida o que Moser chama de aproximação entre mídia e arte, quando então a midialidade da arte passa a ser melhor estabelecida e conhecida. No que concerne a relação entre filme e pintura, a questão a se levantar será saber como o filme remedia a pintura.

Há para Moser um aspecto paradoxal na relação entre arte e mídia que merece ser iluminado aqui. Se por um lado, a mídia tende a se conservar transparente, não visível e propiciadora de um contato direto entre arte com o público - o que oculta também, no limite, as próprias relações de intermidialidade anteriores que são subjacentes a uma determinada arte -, por outro lado, a relação entre as artes fomenta a interação entre mídias, trazendo de volta à visibilidade a mídia antes tornada transparente. 
Para a finalidade desta pesquisa, não é preciso adentrar nos detalhes dos exemplos trabalhados por Moser, mas, sim, entender o porquê do autor tê-los escolhido para falar de uma visão arqueológica das mídias:

O caso romântico demonstrou que as relações entre as artes, altamente complexas, que os artistas encenam em suas obras contém o potencial de uma intermidialidade explícita, além de tornar mais visível a midialidade da arte. O dispositivo de relação entre as artes, duplicando-se em um dispositivo intermidial, desenvolve uma função heurística na medida em que dá a ver e a conhecer a midialidade da arte. (MOSER, 2006, p. 54)

E, também, explicitar seu argumento sobre a transparência para a qual tende a midialidade das artes, já que tal ideia nos permite pensar os quadrinhos em um escopo mais amplo.

Por um lado, toda mídia nova pretende, enfim, propiciar acesso direto ao real - ela fará valer então sua transparência, até mesmo sua inexistência (transparency, immediacy) em relação àquilo que vai mediar. Por outro lado, esse apagamento da mídia é obtido por um acréscimo no nível do aparelho midiático e a mídia exibirá orgulhosamente sua sofisticação de funcionamento midiático (hypermediacy). (MOSER, 2006, p. 56).

A recriação, a reedição, enfim, a apropriação de uma mídia por outra, operando o reajustamento de formas e conteúdos, tende a tornar transparente e vestigial a mídia anterior. Acrescente-se a isso o dado da sofisticação tecnológica, o que, para Moser, paradoxalmente, faz brilhar a nova mídias e suas possibilidades. A esse respeito, o texto de "Arte e Mídia: aproximações e distinções", de Arlindo Machado acrescenta ainda aspectos importantes que merecem ser considerados:

O que faz, portanto, um verdadeiro criador, em vez de simplesmente submeter-se às determinações do aparato técnico, é subverter continuamente a função da máquina ou do programa de que ele se utiliza, é manejá-los no sentido contrário de sua produtividade programada. Talvez até se possa dizer que um dos papéis mais importantes da arte numa sociedade tecnocrática seja justamente a recusa sistemática de submeter-se à lógica dos instrumentos de trabalho, ou de cumprir o projeto industrial das máquinas semióticas, reinventando, em contrapartida, as suas funções e finalidades. As técnicas, os artifícios, os dispositivos de que se utiliza o artista para conceber, construir e exibir seus trabalhos não são apenas ferramentas inertes, nem mediações inocentes, indiferentes aos resultados, que se poderiam substituir por quaisquer outras. Eles estão carregados de conceitos, eles têm uma história, eles derivam de condições produtivas bastante específicas. A artemídia, como qualquer arte fortemente determinada pela mediação técnica, coloca o artista diante do desafio permanente de, ao mesmo tempo em que se abre às formas de 
produzir do presente, contrapor-se também ao determinismo tecnológico, recusar o projeto industrial já embutido nas máquinas e aparelhos, evitando assim que sua obra resulte simplesmente em um endosso dos objetivos de produtividade da sociedade tecnológica. (MACHADO, 2004, p. 5-6)

A dimensão política e artística dessa apropriação tecnológica pelo artista o livra da submissão aos modos padronizados da tecnologia e tende a distanciá-lo dos clichês da cultura de massa.

Ele (o artista) busca interferir na própria lógica das máquinas e dos processos tecnológicos, subvertendo as "possibilidades" prometidas pelos aparatos e colocando a nu os seus pressupostos, funções e finalidades. O que ele quer é, num certo sentido, "desprogramar" a técnica, distorcer as suas funções simbólicas, obrigando-as a funcionar fora de seus parâmetros conhecidos e a explicitar os seus mecanismos de controle e sedução. (MACHADO, 2004, p. 9)

Nesse intervalo crítico, o artista opera de forma criativa, fazendo as tecnologias trabalharem a serviço de suas ideias. Chama a atenção de Machado o aparente paradoxo no gesto do artista de recorrer às tecnologias e ao mesmo tempo subvertê-las numa lógica que não visa a eficiência da mídia mas, antes, a expressão artística. Para ele, a artemídia deve

(...) traçar uma diferença nítida entre o que é, de um lado, a produção industrial de estímulos agradáveis para as mídias de massa e, de outro, a busca de uma ética e uma estética para a era eletrônica. $\mathrm{O}$ fato mesmo das suas obras estarem sendo produzidas no interior dos modelos econômicos vigentes, mas na direção contrária deles, faz delas um dos mais poderosos instrumentos críticos de que dispomos hoje para pensar o modo como as sociedades contemporâneas se constituem, se reproduzem e se mantêm. Pode-se mesmo dizer que a artemídia representa hoje a metalinguagem da sociedade midiática, na medida em que possibilita praticar, no interior da própria mídia e de seus derivados institucionais (portanto não mais nos guetos acadêmicos ou nos espaços tradicionais da arte), alternativas críticas aos modelos atuais de normatização e controle da sociedade." (MACHADO, 2004, p. 6)

Voltando ao questionamento de Moser, o que ele quer saber, em um primeiro momento, é se é possível falar em uma “cena original” da intermidialidade. Na realidade essa indagação, no estilo socrático, é precisamente o que o autor deseja refutar: o que Moser procura mostrar é que o romantismo oferece um contexto privilegiado para que se perceba as questões intermidiáticas que fazem parte de toda arte, e, sobretudo, que existe sempre, em todas artes, uma estrutura subjacente à intermidialidade, qualquer que seja o momento histórico em que emerja. 
Considerando-se que a pintura, enquanto arte visual, pode genealogicamente ser considerada como um ancestral do cinema, não é surpreendente que a referência à pintura, bem como sua inclusão, em filmes acompanhe toda a história do cinema. (...) Os filmes gostam muito de interagir e de dialogar com seu ancestral, a pintura, seja em uma relação de espelho intermidiático, seja na encenação de um paragone não isento de rivalidade, seja ainda em uma reflexão metacrítica sobre sua própria midialidade visual. (MOSER, 2006, p. 53)

Se concordarmos com Moser que a pintura é o ancestral do cinema, com mais razão será possível argumentar que ela é também ancestral dos quadrinhos, que por sua vez são também herdeiros da poesia e da literatura. Inspirado nas ideias de Moser, e adaptando seu argumento ao contexto que aqui nos interessa, este estudo propõe olhar para os quadrinhos como uma arte/mídia que se debruça sobre seu próprio passado para interrogá-lo e explorá-lo de diversas maneiras.

O que nos permite identificar algo como "quadrinhos" não advém de uma detecção de "especificidade" passível de ser deduzida de aspectos ontológicos. Antes, o que permite essa referência é a presença de certos recursos variáveis que acabaram por se convencionalizar nos quadrinhos impressos. Delimitar, portanto, os quadrinhos segundo um conjunto fixo de mídias e procedimentos seria engessálo a formas equivocadamente assumidas como imutáveis. Seria também, em última instância, esquecer que a linguagem dos quadrinhos é constitutivamente uma linguagem marcada pela intermidialidade, ou seja, ela nasce a partir de investimentos expressivos de se fazer uma arte se relacionar com outras, em diferentes mídias, e se inscreve numa longa tradição de relações entre as artes, como procurarei argumentar.

\section{3}

\section{A intermidialidade na leitura do intervalo dos quadrinhos: janela para uma arqueologia da intermidialidade}

O presente item, em perspectiva interdisciplinar, propõe verificar em que medida a noção de "leitura do intervalo", de João Alexandre Barbosa, oferece uma chave valiosa de entendimento também para a leitura dos quadrinhos, dando acesso às tensões resultantes da relação entre a ficcionalidade nos quadrinhos e os 
elementos externos que a ela se ligam, entre os quais, como se buscará argumentar aqui, os que dizem respeito às relações de intermidialidade, e mais propriamente, para o caso que aqui se deseja tratar, às remediações da literatura e da pintura pelos quadrinhos.

Assume-se aqui que a história, como proposto por João Barbosa, sendo um dado da realidade, é um elemento exterior à textualização da história na obra, ou seja, é exterior à literatura. Ora, no caso dos quadrinhos é possível reconhecer o mesmo, que a história, como dado da realidade, é parte dos elementos de sua leitura, sofrendo influência de seus dispositivos textuais. E é na dimensão histórica que se encontram os elementos que ajudam a compor uma compreensão arqueológica da intermidialidade.

Embora não fale em intermidialidade, a perspectiva de João Barbosa sobre a leitura da literatura, ao chamar atenção para os elementos externos à literatura que lhe são constitutivos (os elementos históricos, culturais e sociais e políticos - todos eles, em alguma medida, relacionados à materialidade da obra), encoraja este estudo a propor que a leitura dos quadrinhos também possa ser vista como leitura do intervalo, uma leitura de onde emergem os vestígios de intermidialidade da obra. Corrobora para este entendimento a compreensão de que as relações de intermidialidade adquirem maior consistência se vistas sob o prisma de seu movimento histórico, de um longo e contínuo processo de remediação de uma arte por outra, ou seja, pelo prisma da arqueologia da intermidialidade a qual implica incluir a dimensão histórica que emerge do intervalo.

Barbosa distingue, na experiência da leitura, o que remete a uma organização específica que dá forma à obra literária e o que remete a um dado da realidade psicológica, histórica e social da obra e do leitor, apontando para elementos exteriores ao texto. Procura ainda mostrar que a leitura literária é construída no movimento entre os significados culturais e a maneira de sua textualização. O mesmo se pode afirmar dos quadrinhos, ressaltando, ainda, que o tom satírico e discursivo que tomavam para si nos jornais imprimiam-lhes um papel abertamente político. 
Essa relação entre cultura e textualização, contudo, como nos lembra Barbosa, não oferece significados independentes entre si; antes, é na composição e aqui se acrescentaria, ainda, na montagem como procedimento de escolha entre o quê e como mostrar e o que colocar na sarjeta - que ela emerge como possibilidade de leitura:

aquilo que se lê como sendo mais que literatura na leitura da literatura é antes um sentido produzido pela própria composição do que uma pressuposição de significados independentes de um certo modo de existir em relação a outros significados. Sendo assim, os elementos psicológicos, sociais ou históricos que são apreendidos a partir da leitura da obra, e que parecem ser mais do que a obra tem enquanto literatura, dada a sua existência dual já referida, são metamorfoses de um sentido mais geral produzido e não somente secretado pela organização da própria obra. Entre o espaço empírico anterior e do reencontro através da leitura, aqueles significados psicológicos, sociais e históricos foram articulados pelo que é literatura na leitura da literatura: a ficcionalidade. (BARBOSA, 1990, p. 17)

A leitura do intervalo nos quadrinhos permite pensar a história como elemento externo à literatura, e também à pintura, mas que retorna como elemento essencial à composição da leitura, a qual inclui os aspectos ligados à materialidade do objeto que é lido. No conjunto de elementos externos à ficcionalidade - quais sejam, os elementos sociais e históricos - incluem-se também, inseparavelmente, aqueles que se ligam à materialidade da obra. Convergindo interdisciplinaridades, a proposta de pensar a leitura do intervalo tendo por base epistemológica a via da intermidialidade acrescenta a materialidade das mídias à leitura concebida por Barbosa.

Importante destacar que o entendimento da leitura do intervalo requer o reconhecimento de mudanças também no lugar ocupado pelo crítico, que passa a se ver em um lugar de tensão, não de pacificação, no qual é demandada a habilidade de perceber, na linguagem literária, como o elemento externo é transformado em interno, ou seja, como a obra literária internaliza as tensões que daí resultam. A leitura do intervalo é "uma leitura insegura, instável, sempre en abîme" (BARBOSA, 2002, p. 28)

Desde os inícios das reflexões poéticas, desde, pelo menos, Platão e Aristóteles, a questão da representação é a contraparte teórica da própria operação poética. E não poderia ser de outra forma de vez que, se instaurando no espaço ficcional, mas traduzindo elementos obtidos nas relações sociais, o poético tem a sua 
singularidade em operar intensamente nos intervalos entre a experiência e a representação da experiência pelos deslocamentos possíveis da linguagem. (BARBOSA, 2002, p. 14-15)

Assume-se a remediação da literatura e da pintura pelos quadrinhos como parte da leitura, parte dos significados acessíveis ao leitor, e tanto mais legível, tanto menos transparente quanto maior a interferência do artista e seu empenho em subverter os aparatos técnicos, explicitando seus mecanismos de sedução, em vez de somente exibi-los ou enfatizá-los. A esse respeito vale a pena citar a passagem em que João Maria Mendes cita a teoria da mediação de Bolter e Grusin e sua oposição ao que Mendes chama de "mito modernista do novo", sempre em busca de novas orientações estéticas e culturais que os distingam de seus anteriores:

A crítica dos media continua cativa do mito modernista do novo: ela assume que as tecnologias digitais como a WWW, a realidade virtual e os computer graphics se devem divorciar dos media seus antecessores, usufruindo de um novo conjunto de princípios estéticos e culturais. Bolter e Grusin desafiam esta concepção, propondo uma teoria da mediação para a era digital: eles argumentam que os novos media visuais alcançam relevância cultural precisamente por homenagearem, rivalizando com eles e redesenhando-os, media como a pintura perspectivista, a fotografia, o cinema e a televisão. Chamam a este processo 'remediação' e anotam que também os antigos media redesenharam os seus antecessores: a fotografia remediou a pintura, o cinema remediou as artes cénicas e a fotografia, como a televisão remediou o cinema, o vaudeville e a rádio. (MENDES, 2011, p. 25) .

Se os "elementos externos" a que Barbosa se refere incluem a intermidialidade como se procurou mostrar aqui faz sentido tentar defender uma noção ampliada de leitura da sarjeta, que não a limite à mera indicação de um espaço entrequadros que a leitura permite acessar em sua busca pela unidade, mas que a veja também como o lugar daquilo que, sem ser quadrinhos, faz parte da leitura dos quadrinhos por referir-se a uma multiplicidade de significados relacionados à experiência do leitor, entre os quais o reconhecimento de certas convenções cuja origem remete às relações de remediação de uma arte por outra. A sarjeta não representa um espaço vazio, mas, antes, um expediente, cujo modo de operar extrapola a representação que torna o intervalo um dado visível. É na leitura da sarjeta, portanto - nessa leitura de um fluxo interrompido/religado por elipses e que se faz por associações e montagem - que o leitor pode reconhecer, graças ao repertório histórico cultural e social da obra e ao seu próprio, a intermidialidade dos 
quadrinhos. Inserida na perspectiva interdisciplinar da arqueologia da intermidialidade, esta pesquisa considera, portanto, que a leitura ampliada da sarjeta nos permite observar - nos intervalos, no movimento da montagem - os vestígios das relações entre mídias.

Argumenta-se aqui que essas relações traduzem-se em processos de remediação de uma arte por outra que remonta à longa tradição ut pictura poesis. Embora já se tenha falado sobre esse tópico em item anterior, faz-se necessário voltar a ele para mais algumas observações. Solange Ribeiro de Oliveira (1987), ex-professora de Literatura Inglesa da UFMG, expõe com objetividade e clareza como a primazia do logos alterou o velho topus horaciano.

\begin{abstract}
A Renascença volta às palavras de Horácio, invertendo-as . Passa a tomar a pintura como termo referencial: é a pintura que deve ser como a poesía, e não o contrário. Dessa forma, tenta-se liberar as artes plásticas da maldição que sobre o elas pesava, desde Platão, o iniciador do longo reino do Logos. Supremo inimigo da imagem, condenada como uma cópia da cópia, ele a relegara a à posição de servil imitadora de uma suposta realidade, que, por sua vez, não passa de sombra da Ideia, ou essência ideal. Melhor justificativa não se poderia encontrar para excluir a pintura das artes liberais, entre as quais se incluía a poesia. A inversão do dito horaciano, operada a partir da Renascença, tem, além das filosóficas, implicações sociais importantes. Se o pintor ou o escultor não é mais um mero artíficie de imagens condenáveis, deixa também de ser o simples cultor da arte mecânica, o mero artesão. Sua arte passa a incluir-se entre as liberais, dignas do homem livre. Pintor e escultor saem da companhia de artesãos e operários livres, onde virtualmente se considerava ser o seu lugar, e passam a integrar a dos artistas. Com o correr do tempo, mesmo com a queda do logocentrismo, a defesa filosófica do artista plástico passa a ser desnecessária. Mas prossegue a orientação crítica resumida nas palavras de Horácio. Continuam a florescer os estudos relacionando literatura e artes plásticas, que alcançam o apogeu no século XVIII. (OLIVEIRA, 1987, p. 131)
\end{abstract}

A pesquisadora chama atenção ainda para aquilo que identificou como "uma concepção semi-literária da pintura" (Ibid, ibidem) oriundo de "um vai e vem crítico entre literatura e artes plásticas" (Ibidem, p. 132). Havia muitos pintores que preferiam paisagens de interesse histórico e literário.

A apreciação dos motivos pictóricos tornava-se dependente de suas possibilidades dramáticas e de associações literárias. Os paralelos entre as artes, iniciados no século XVII por Du Jon e Du Fresnoye (traduzido por Dryden, autor de Parallel of poetry and painting) são aplaudidos e elaborados ao longo do século XVIII, quando se multiplicaram os quadros ilustrativos de temas históricos. Afirmava-se que a pintura era semelhante à poesia pelo fato de representar "fábulas" e de 
submetê-las à apreciação do intelecto. Como a poesia, argumentam os críticos, uma obra de arte plástica deveria ter unidade de concepção, mostrar subordinação das personagens secundárias às principais, decoro e relevância na escolha dos detalhes, etc. (...) O século XVIII, separando o estudo de forma e conteúdo, comparava a palavra a um ornamento semelhante à imagem decorativa, a ser tratada independentemente do assunto e da estrutura. Dentro dessa orientação, as semelhanças entre as artes pareciam sobrepujar as divergências. Até o Laocoonte de Lessing (1776), não ocorrem as mudanças necessárias para uma nova orientação crítica. Elas só acontecerão quando se compreender a importância vital do meio utilizado em cada arte e as consequentes diferenças de concepção e expressão. Antes da mudança de atitude crítica assinalada por Laocoon, a poesia é freqüentemente tratada como uma forma de pintura. (OLIVEIRA, 1987, p. 132)

A introdução da materialidade como elemento fundamental à arte encontra em Lessing, como remarca Oliveira, um marco importante nas discussões sobre as artes, motivando-as a ir além da comparação que ora sobrepunha uma forma, ora outra. A posição de Lessing antecipou posicionamentos modernos, contrariando a tradição que ignorava a materialidade da arte.

A pintura,com suas imitações, emprega meios ou signos totalmente diferentes dos da poesia - figuras e cores no espaço - enquanto a última utiliza sons articulados em ordem temporal: como, indiscutivelmente, os signos usados devem ter uma relação precisa com o objeto representado, segue-se que os signos dispostos lado a lado podem expressar temas que, no conjunto ou em suas partes, existam dessa forma, enquanto os sinais que se sucedem no tempo podem expressar elementos que, no todo, ou em parte, sejam sucessivos. (OLIVEIRA, 1987, p. 139)

Esse breve resgate da discussão da ut pictura poesis nos deixa ver a influência do pensamento platônico em nossa forma de entender a relação da pintura com a poesia. Para Platão nenhuma das duas era confiável, ambas davam apenas uma falsa simulação da realidade. No Renascimento, a relação entre ambas passa a ser de disputa, e nessa quebra de braço foi reconhecida a pintura como precedente e superior, e diferença amparava-se na consideração de que a visão (imagem) era um sentido mais confiável que a audição (poesia é uma arte do tempo).

Olhar os quadrinhos pela perspectiva de uma "arqueologia da intermidialidade" não significa necessariamente pretender qualquer tipo de retrospectiva histórica. Antes, implica considerar os quadrinhos a partir de um ângulo que nos permita ver os vestígios de outras artes, pela recriação de seus 
conteúdos e formas. Não se busca aqui, vale repisar, uma definição para quadrinhos, seja ela inclusiva ou exclusiva. Pretende-se ir além da mera captura de um instantâneo, ou de uma definição ontológica do objeto quadrinhos, e em favor de um olhar que transversa suas várias camadas em estado de constante reconstrução.

Se, por exemplo, definimos a intermedialidade em termos de encontro e de relação entre duas ou mais práticas significantes - música, literatura e pintura, suponhamos, no seio de um media, o cinema — , o ponto de partida é ainda o da preexistência e da identidade das práticas separadas, e o ponto de chegada exprime, por seu turno, os resultados desse encontro : a identificação dos momentos híbridos, a análise dos mistos, etc. O fluxo é analisado, portanto, imobilizado e decomposto. [Ora], a intermedialidade está mais do lado do movimento e do devir, lugar de um saber que não será o do ser. Ou então é o lugar de um pensamento do ser já não entendido como continuidade e unidade, mas como diferença e intervalo. (MARINELLO, 2000 apud MENDES, 2011)

É preciso reconhecer, contudo, que a consolidação dos quadrinhos como produto impresso de amplo consumo estabelece um ponto importante de assimilação dessa arte por uma mídia - a imprensa -, firmando pari passu a consolidação de muitas convenções, e dando a ideia de serem os quadrinhos uma realização autônoma, com um marco de origem.. Em decorrência dessa percepção, a relação dos quadrinhos com outras artes tende a se tornar transparente para o público. Na contramão dessa percepção, argumenta-se aqui que não é possível pensar os quadrinhos - nem sua história, nem seus horizontes - sem considerar o contexto de intermidialidade em que se desenvolveram, até serem incorporados pela mídia impressa e nela adquirirem certa identidade.

A compreensão dos quadrinhos se faz a partir de uma intermidialidade anterior e com a ajuda desta. A compreensão desse objeto demanda pensá-lo em sua relação com outras mídias, outras artes, tendo em vista a influência da materialidade sobre o efeito estético.

É no momento estésico da interpelação dos sentidos que arte e mídia se entrelaçam, mas o aparelho midiático, com suas dimensões materiais, técnicas, sociais, econômicas, etc., ultrapassa muito essa zona de contato concreta. O dispositivo das relações entre as artes, com suas estratégias e práticas muito variadas, permite ao artista anular a transparência da mídia, tornar a midialidade da arte opaca e, assim, reconhecida. A interseção e a interação concreta entre duas artes, que implica sempre também aquela entre duas mídias, revela-se, portanto, como um caso 
privilegiado para se pensar a midialidade em um contexto que já é intermidiático. (MOSER, 2006, p. 63-64.)

Apropriando-se da terminologia criada por Bolter e Grusin, esta pesquisa utiliza o termo remediar tal como o fez Moser ao captar nesse verbo um conjunto amplo de operações possíveis: "retomar, reproduzir, re-(a)presentar, reutilizar, reciclar, revisitar, transferir, transmitir, transcodificar, transpor, etc". Essas operações mostram-se esclarecedoras na construção de uma percepção mais ampla e complexa de quadrinhos, e nos põe diante de uma nova perspectiva de análise desse objeto - a que nos coloca diante do horizonte de uma arqueologia da intermidialidade.

Já que nossa busca arqueológica chegava a uma configuração cujo modo de existência remete a um "sempre já", descobrimos uma estrutura ou uma lógica que nos permite articular as condições de possibilidade da intermidialidade a partir, e dentro, da realidade da arte. Com isso, estamos mais perto da acepção foucaultiana de arqueologia do que de qualquer busca de origem. (MOSER, 2006, p. 63)

Antes de concluir, vale a pena evidenciar que não se considera na perspectiva adotada nesta dissertação a possibilidade de olhar para as relações de intermidialidade entre a literatura e os quadrinhos como apropriação por parte dos quadrinhos de uma suposta forma literária da linguagem, tampouco considerar que essa relações se dão apenas a partir de experimentos que motivaram a criação do termo romance gráfico em fins de 1980, como supõem alguns, especialmente para criticar a relação dos quadrinhos com a literatura. Uma vez que tal hipótese é comum tanto nos estudos de intermidialidade quanto em outros campos interdisciplinares, vale a pena nos determos um pouco na questão.

Como se procurou mostrar no segundo capítulo desta dissertação, a expressão 'romance gráfico' não surgiu para nomear uma prática inédita de recriação da literatura nos quadrinhos, mas para dar ênfase ao interesse de alguns autores de quadrinhos, de um lado, em romper com certos conservadorismos que predominavam no meio (extensão da obra, seu acabamento editorial, seus temas) e, por outro, em inserir os quadrinhos no grupo dos objetos cujo valor artístico poderia 
ser reconhecido. Will Eisner, como escreve Scott McCloud em seu livro ${ }^{10}$, foi severamente criticado por seus pares quando, já na década de 1930, cogitou a hipótese de aproximar quadrinhos de arte ou literatura. Na década de 90, a recepção não apenas foi diferente como marcou significativa mudança na recepção dos quadrinhos por parte da comunidade crítica: em 1992, como é bem conhecido, o prêmio Pulitzer, dedicado ao jornalismo e à literatura, foi dado aos quadrinhos Maus, de Art Spiegelman.

\section{4}

\section{A montagem nos quadrinhos como remediação da pintura e da literatura}

A relação de intermidialidade entre os quadrinhos e a pintura remonta à relação de intermidialidade histórica entre pintura e literatura. No século XVIII, consideram-se os trabalhos de William Hogarth, pintor e gravador inglês, como cena privilegiada de observação da remediação da literatura pela pintura. Hogarth justapunha imagem e texto em gravuras que guardavam ordem sequencial entre si. Sua atuação profissional mostrou-se política em vários níveis: quando a pintura se ocupava apenas de quem podia pagá-la, Hoggarth foi um dos primeiros a pintar retratos dos trabalhadores pobres e ganhou a reputação de ser um brilhante artista satírico; para findar com a pirataria das suas gravuras mais populares, conseguiu em 1735 a aprovação de uma lei sobre direitos de autor, conhecida por Lei de Hogarth, e oficialmente como Engravers' Copyright Act; e criou a Academia de Saint Martin's Lane, uma escola para jovens gravadores.

Outro marco fundamental na construção do que hoje se chama histórias em quadrinhos foi o suíço Rodolphe Topffer. A obra Histoire de Mr. Jabot, publicada em 1833, de Topffer, é por muitos considerada aquela que inaugura a história em quadrinhos moderna. A grande popularidade dos trabalhos de Töpffer foi fator

\footnotetext{
${ }^{10}$ Scott McCloud, Recriando os Quadrinhos, pág.26
} 
decisivo no estabelecimento das convenções básicas e da "virada" narrativa da forma sequencial. Se a prática de contar histórias com imagens e palavras remonta ao início da prática representativa humana, é possível, contudo, admitir que o que Topffer manifesta traz algo de novo para a montagem de caricaturas, para os quadros e requadros e para a narrativa com alguma unidade de ação. Traz também dinamismo e comicidade próxima do burlesco A sequencialidade dos desenhos, a organização dos quadros, a impressão em álbum, a preocupação em ligar de forma clara texto e imagem mostram que o autor buscou experimentar uma nova linguagem. Um episódio marcante de leitura de Topffer se deu em 1830, envolvendo Johann Wolfgang von Goethe (1749-1832), e seu amigo Frédéric Soret (1795-1865), que lhe mostrou algumas histórias desenhadas recontando as escapadas cômicas de um sujeito em busca de sua noiva imaginária, uma trama em que entram árvores falantes, telescópios voadores e astrônomos de um olho só. Os manuscritos - L'Histoire de M. Cryptogame (1830) e Voyages et aventures du Dr. Festus (1829) - eram de um professor chamado, Rodolphe Topffer, antigo colega de escola de Soret. Eles eram desenhados num estilo solto e rabugento e possuíam uma tendência geralmente irreverente e anti autoritária, repudiando o ideal romântico de perfeita fusão entre homem e mulher e zombando do clero, dos militares e dos homens da ciência. Apesar de sua repulsa declarada à caricatura, Goethe apaixonou-se pelo trabalho provavelmente porque eles - em contraste com o trabalho dos cartunistas que ele criticava, não eram abertamente políticos em seu conteúdo. Em uma carta a Topffer, Soret escreveu:

Goethe manteve os dois álbuns por alguns dias, olhando apenas uma dúzia de páginas de cada vez, descansando depois, porque, disse ele, arriscava ter uma indigestão de idéias. Depois de um tempo, ele os enviou a mim com uma carta, na qual ele escreveu o seguinte, que eu cito por você: Eu lhe envio, com gratidão, os livros pequenos e estranhos. [...] Nos romances caricaturados, só se pode admirar a multidão de motivos que ele [o autor] extrai de um número tão pequeno de caracteres; ele envergonha o mais fértil inventor de combinações, e é preciso elogiá-lo por seu talento inato, claro e sempre pronto. Soret também escreveu que Goethe disse: é realmente muito louco e estranho, mas realmente brilha com talento e inteligência; artisticamente, observa-se como a arte do desenho, o trabalho esboçado, exibe quanto $\mathrm{M}$. Töpffer poderia alcançar, se ele percebesse todo o seu potencial. (WIVEL, 2007)

O trabalho de Topffer foi bem recepcionado pela comunidade crítica da época, embora houvesse ressalvas em relação aos resultados obtidos, a ideia 
reconhecidamente abria caminho para a criação de uma nova linguagem. Os trabalhos de Hogarth e Topffer, contemporâneos entre si, mostram preocupação narrativa clara e constituem um passo significativo no campo das experiências de remediação da pintura pela literatura. Um olhar arqueológico da intermidialidade dos quadrinhos pode neles, encontrar importantes vestígios, sem dificuldade. Nesse aspecto, diferem do igualmente contemporâneo William Blake, cujas obras - a exemplo dos “Trabalhos de Jó” da Bíblia, da "Divina Comédia”, de Dante Alighieri, e do Livro da Inocência e da Experiência - partiam de fontes literárias para ilustrálas. O cunho crítico comparece constante nos três autores, ainda que sob enfoques diferentes.

O caso de William Blake foi examinado em seção anterior, pela leitura de Walter Moser. Já Hoggarth e Topffer trazem o discurso, o logos, a palavra da literatura para a imagem, complexificando-a, satirizando-a. As obras desses dois autores - Topffer e Hoggarth - nos dão exemplos contundentes de investimentos narrativos na pintura e na gravura -e por meio delas temos fortes vestígios de remediação de uma arte por outra como condição de possibilidade para a emergência dos quadrinhos.

Existe, contudo, ainda um outro dado importante a considerar na remediação da pintura pelos quadrinhos para o qual este trabalho gostaria de chamar atenção: as molduras dos quadros. A partir do final do século XIX, como afirma Fabio Luiz Carneiro Mourilhe Silva, em "O quadro nos quadrinhos":

As molduras e a disposição dos quadros, segundo Curry (2000), há muito tempo tem um impacto significante nas experiências do espectador nas galerias. (...) as molduras tradicionais, 'túmulos dourados' na parede, gradualmente foram substituídas por molduras simples, como no trabalho de Whistler onde foi introduzida uma prática de uma moldura mínima para impressões, molduras finas em branco com margens largas para suas águas-fortes e litografias. Esta mudança de concepção da moldura na pintura coincidiu (grifo meu) com o formato simples utilizado nos quadros de tiras de jornais em quadrinhos no começo do século XX. (SILVA, 2010, p. 20)

A história ilustrada de Blake nos mostra que o escrito, como "autoridade estabelecida da lei patriarcal" e o escrito como "processualidade presente e eficaz" 
equilibram-se, sem permitir que se diga se a imagem precede a palavra ou o contrário.

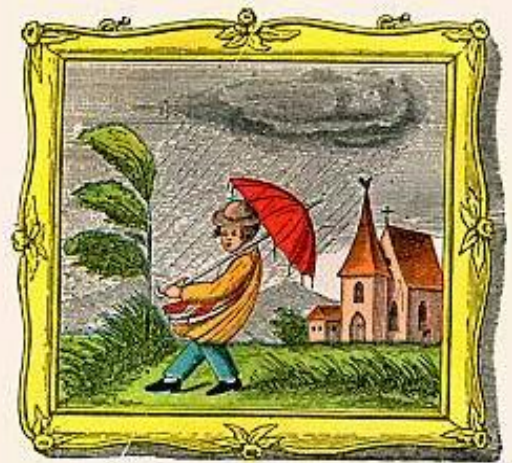

\author{
Dic (5e/dididte \\ vom flicgetion kobert.
}

23ettu ócr Regen nieberbtauft,

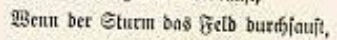

פLetíen MRäbdien ober Mutben

รübid) baljeitn int ilgrent Stuben, -

Mo o bert abee bahte: giein!

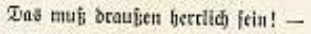

$11 \mathrm{nb}$ im శrelbe patijict et

Mit bem 9ieqcitiditu umber.
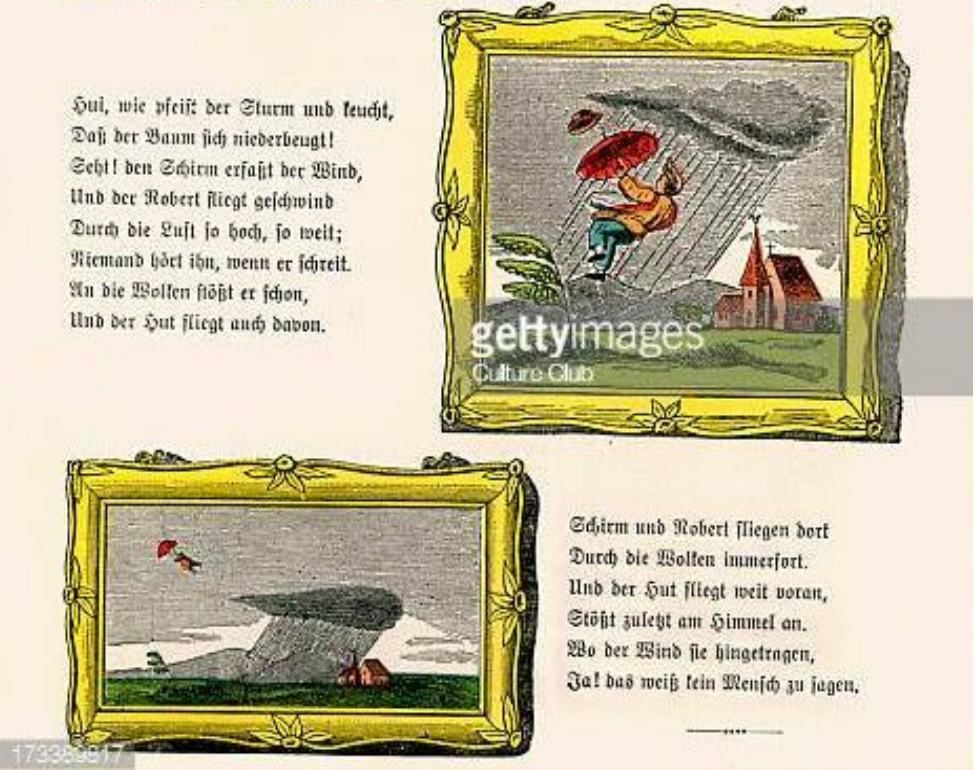

Gdititut utb Mobert filegen bort

Durdi bit 13olten inuterfort.

Unb ber sut filegt woeit vorant,

Etögt zuléft ant 5̧imutet an.

$2 g_{0}$ ber $23 i n d$ fie hilingetrnacti,

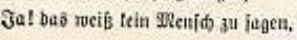

Figura 26 - Struwwelpeter, Heinrich Hoffmann, 1845. S/n

Os dados históricos de que nos informa Fábio Silva são bastante significativos e parecem apontar para uma zona de diálogo entre quadrinhos e quadros. Na visão desta pesquisa não são coincidências, contudo, como afirma o autor, mas experimentos de linguagem que são feitos a partir da remediação proposital de uma arte por outra. Em 1845, Heinrich Hoffmann mantinha o valor da moldura, representando-a nos quadrinhos, o que, por um lado, reforçava a insistente centralidade do texto em relação à imagem, e, por outro, a narratividade da própria pintura. Mantinham-se, contudo, lado a lado na página, sem figurarem justapostos. Outro exemplo interessante que permite contemplar a intermidialidade entre quadrinho e pintura nos remete ao século XX: 
Em trabalhos de Mondrian entre 1916 e 1917, temos a inclusão de painéis retangulares suspensos em fundo branco, indicando uma ruptura dos limites do quadro; e mais tarde, segundo Curry (2000), muitos trabalhos contemporâneos passaram a ser expostos sem moldura, o que corresponde principalmente às pinturas minimalistas da década de 1970, um enfoque com origem em retratos não acadêmicos e abstrações modernistas." (SILVA, 2010, p. 21)

Se os quadrinhos remediaram a moldura como contexto da pintura (e arte é contexto), transpondo sua presença de uma mídia para outra, a pintura, por sua vez, remediou também os quadrinhos e suas sarjetas ao incorporar a ideia de linhas divisórias no campo das telas de pintura. E a pintura os remediou, também, diminuindo o tamanho das molduras.

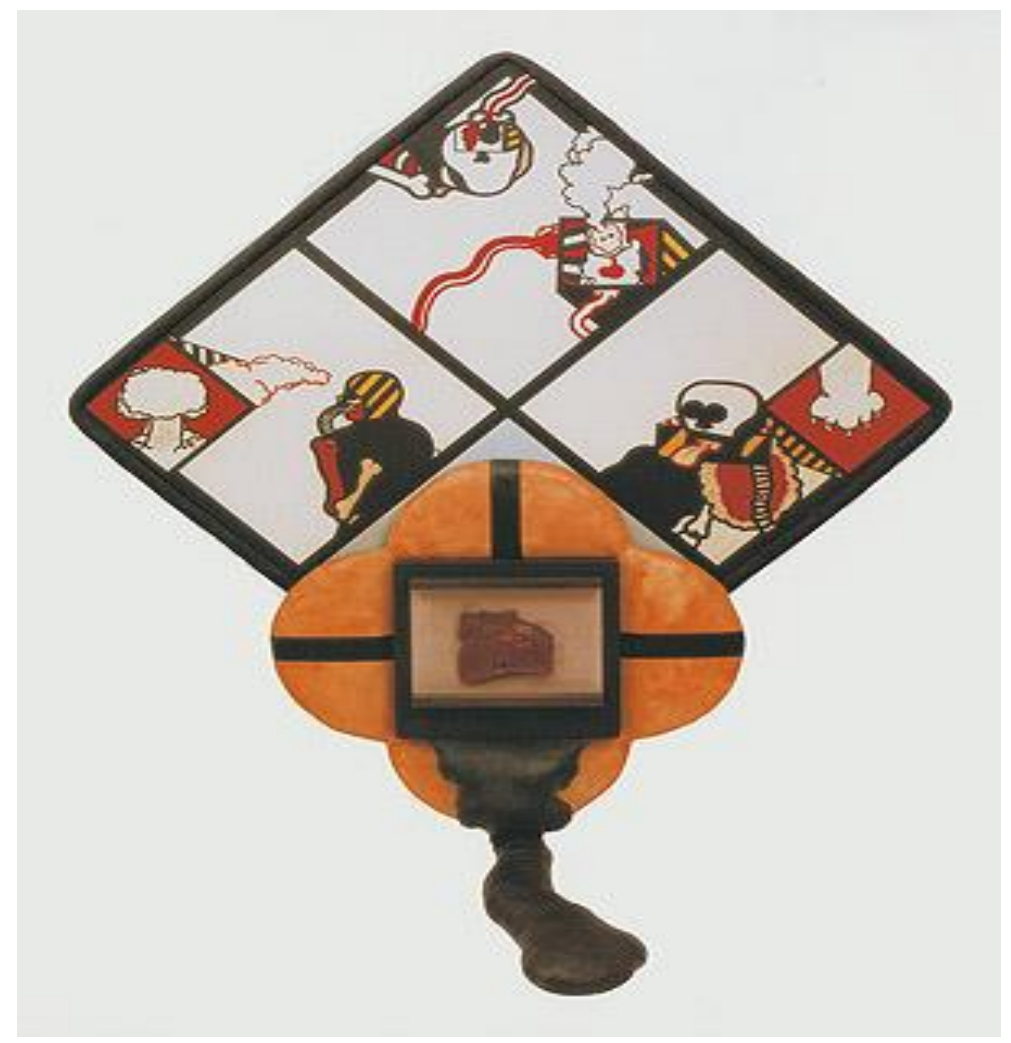

Figura 27. Antônio Dias. Nota sobre morte imprevista. Referências completas na bibliografia.

A obra de Bill Griffith sobre Rosseau, em 1975, recoloca o aspecto da moldura de novo nos quadrinhos, mas dessa vez a remediação se faz para lembrar da moldura e não para obedecê-la. E esta tende a diminuir cada vez mais, até sumir de vez, tornando transparentes as relações dos quadrinhos com a pintura - e opacas 
apenas nos casos em que se deseja lembrá-la. Na década de 1930, com o sucesso dos suplementos dos jornais e das revistas americanas em quadrinhos, a moldura viu-se cada vez mais reduzida até ser limitada a bordas simples.

Devemos pensar em termos de quadros. Não como pinturas emolduradas, mas como um quadro com um conteúdo diverso que é perceptível e comparável simultaneamente e, desta forma, acessível...' (Aicher apud Wildbur \& Burke, 1988, apud Fabio Silva, 2010).

$\mathrm{O}$ requadro uniformizado nas histórias em quadrinhos remediando um recurso da pintura o transforma em recurso quase ausente (transparência) e ao mesmo tempo presente, utilizado na condução da narrativa. 


\section{Ensaio Gráfico Biocêntrico JARDIM DAS SINAPSES}

Quadrinhos

Criação, Direção e Texto: Ana Amado / Conceito e Pintura: Sergio Manon 


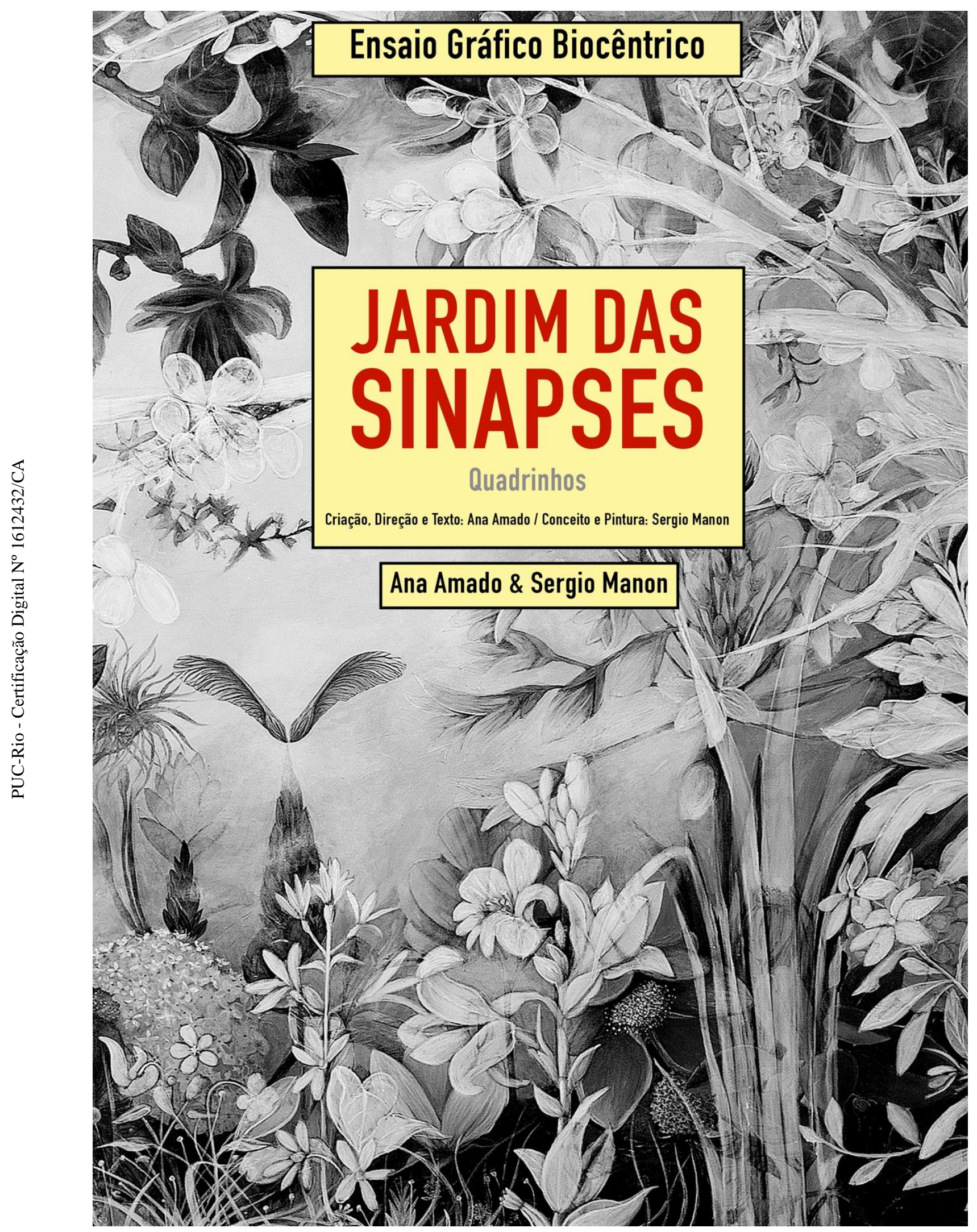




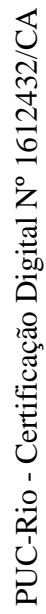

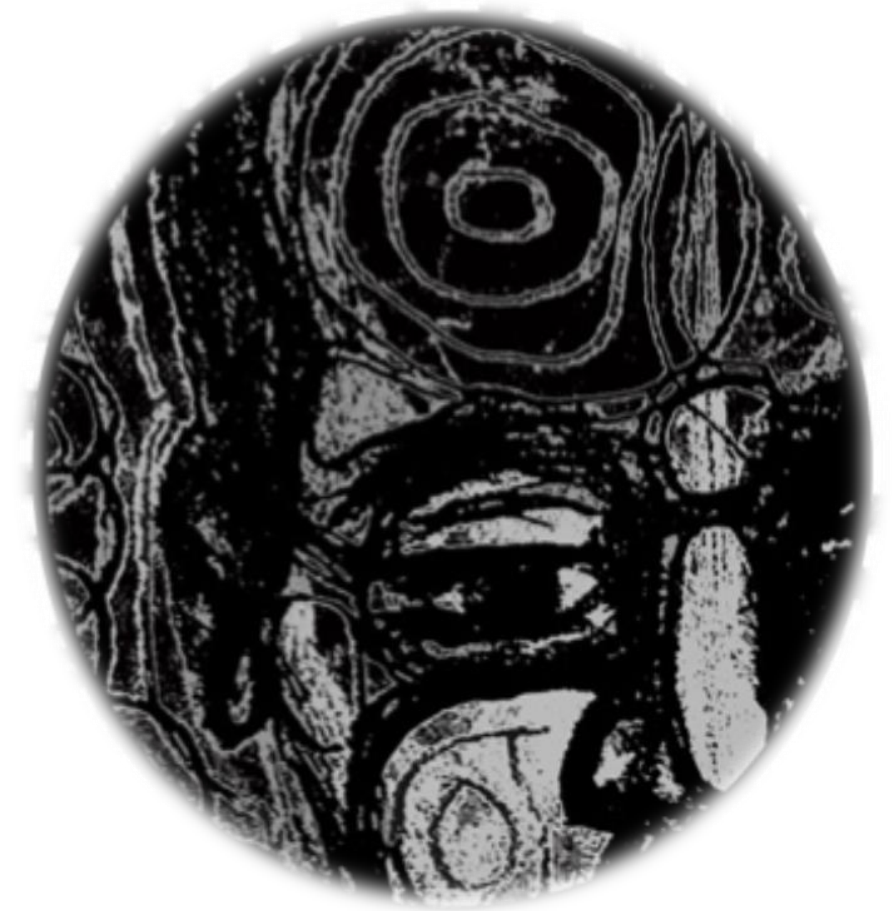


Esta obra em quadrinhos faz apenas um pedido aos leitores: que se abram à escuta do silêncio e se deixem vagar na leitura dos vazios onde floresce a possibilidade de muitos sentidos. No "Jardim das Sinapses", o solo é fertilizado pela intermidialidade que nos convida a ver no diálogo entre quadrinhos, pintura e literatura um outro olhar sobre a pesquisa de Sergio Manon. Temos aqui um ensaio gráfico biocêntrico, uma obra que convoca o leitor a problematizar o antropocentrismo de nosso olhar e a cultivar com a imaginação a perspectiva das plantas. A consciência vegetal, sua cultura e comportamento, temas até então restritos ao discurso da ciência, assumem aqui expressão estética e política, e nos convocam a olhar o mundo como uma grande inteligência, uma grande rede onde cada forma de vida está ligada ao todo em equilíbrio interdependente.

Ana Amado 

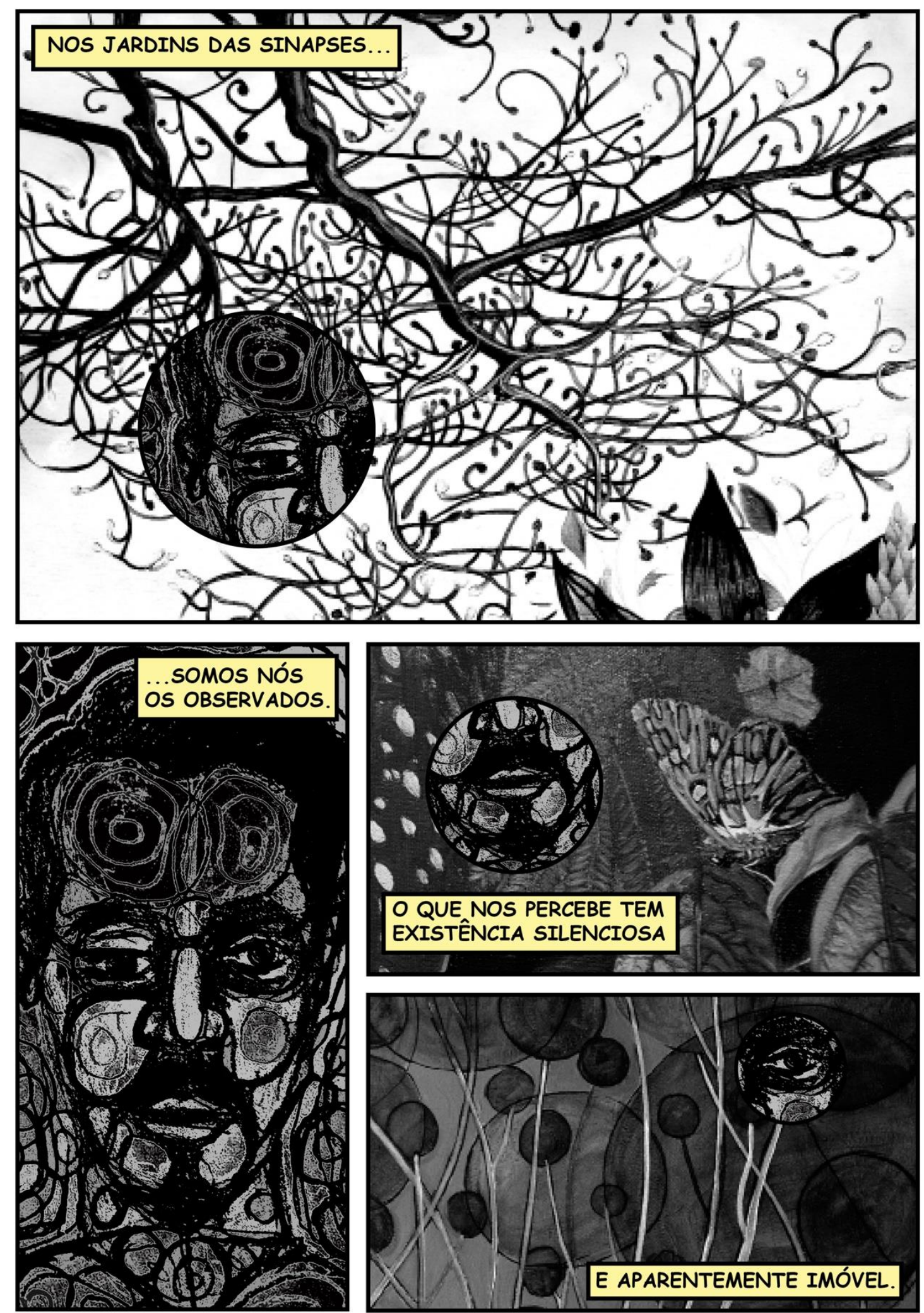

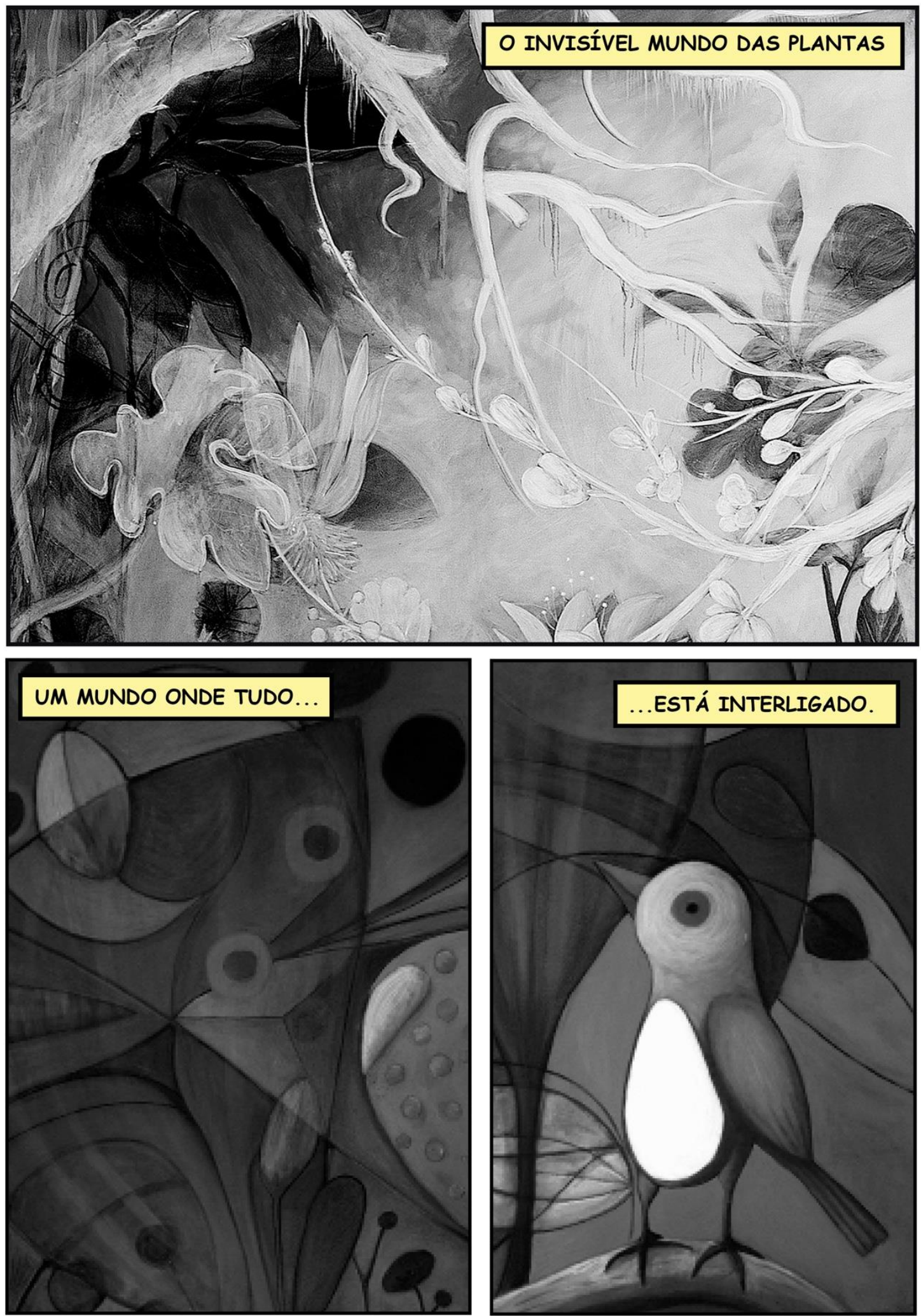

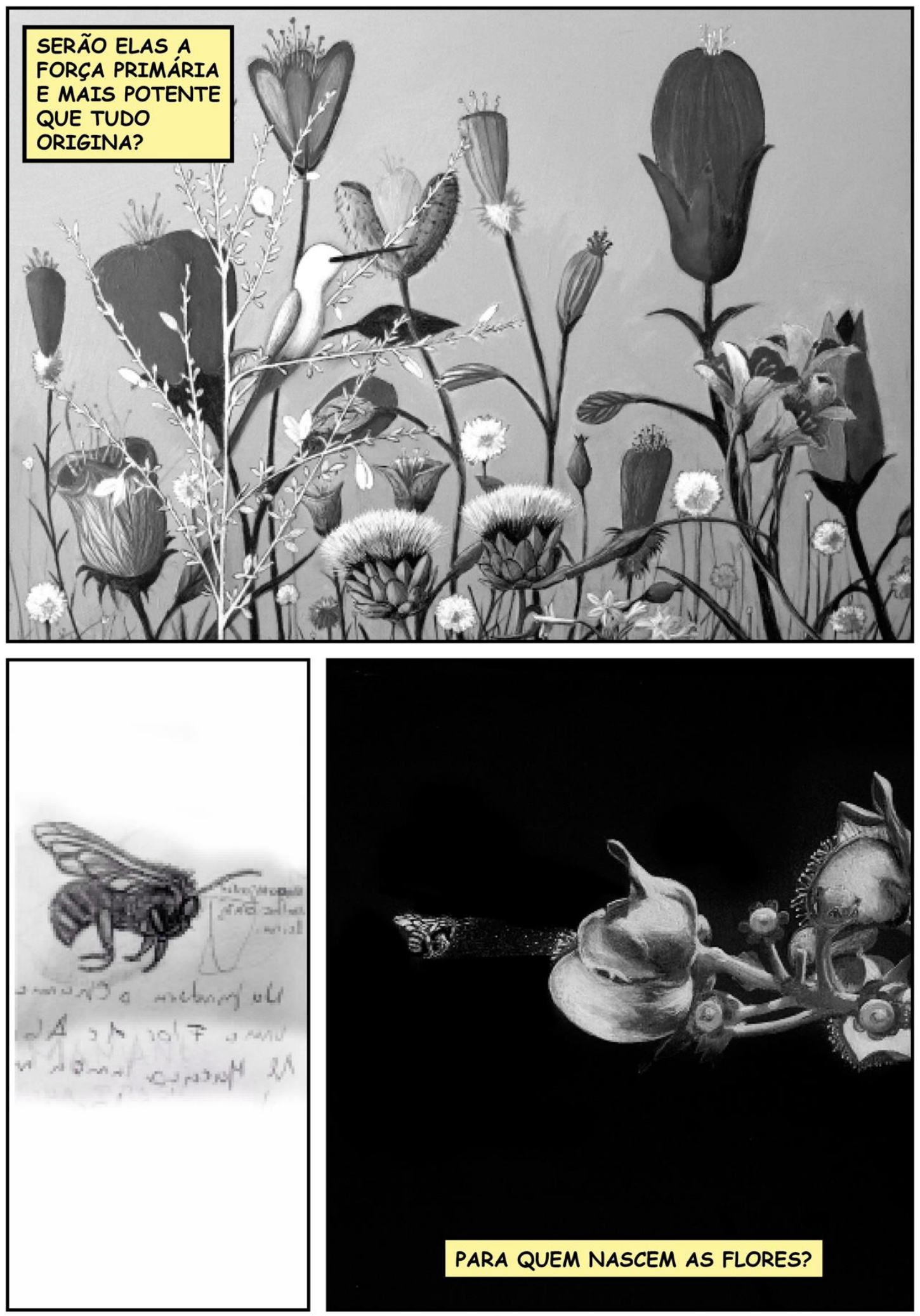

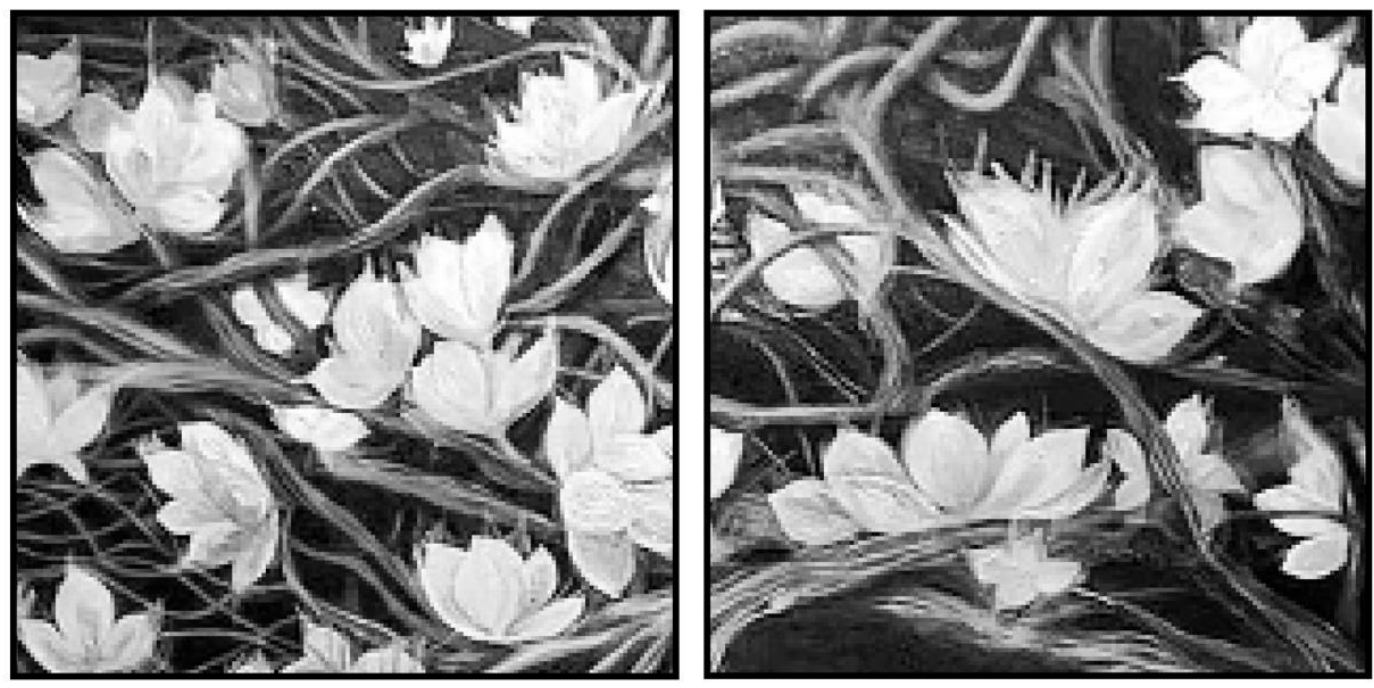

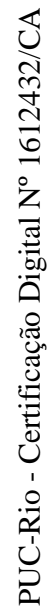
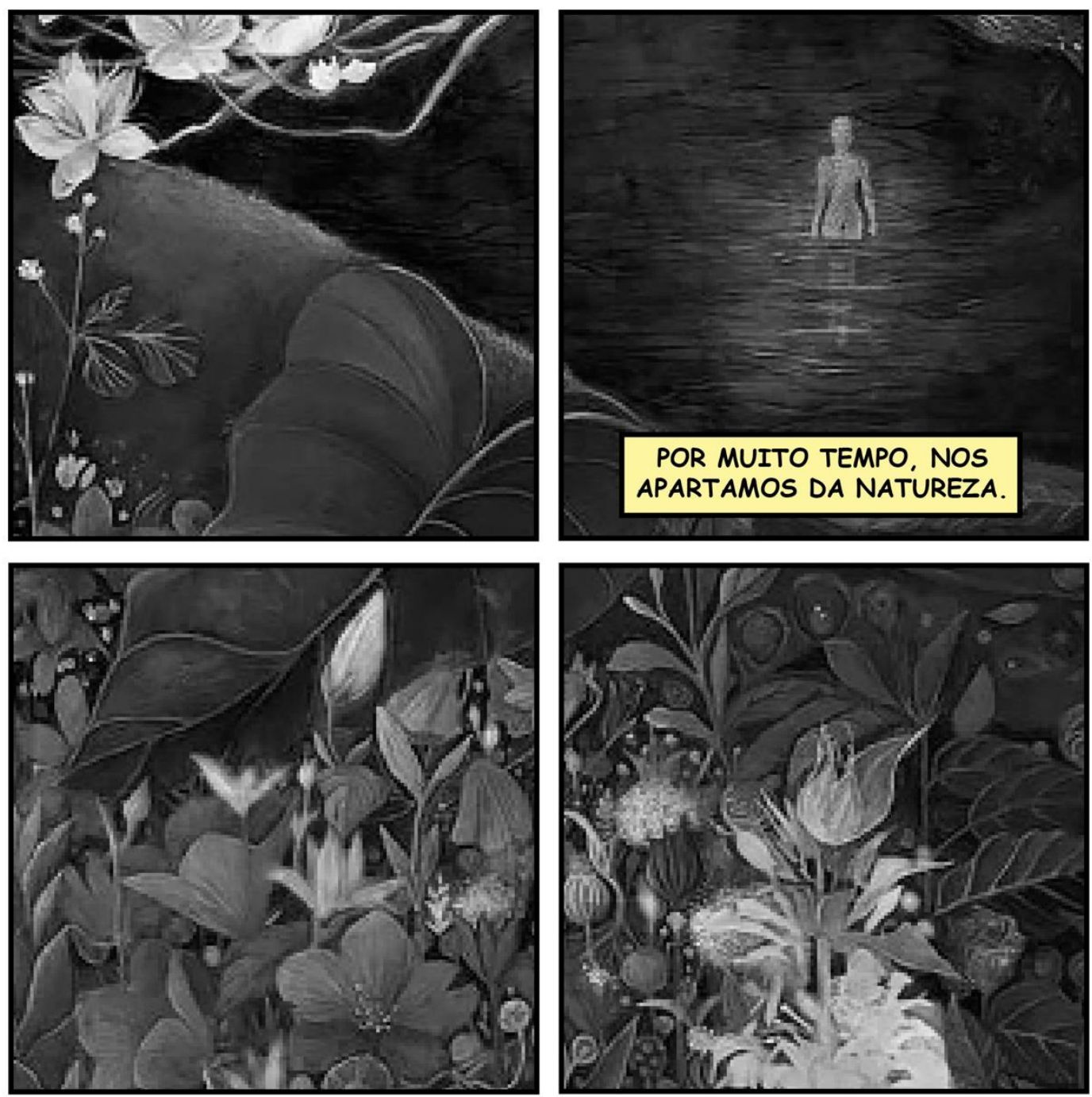

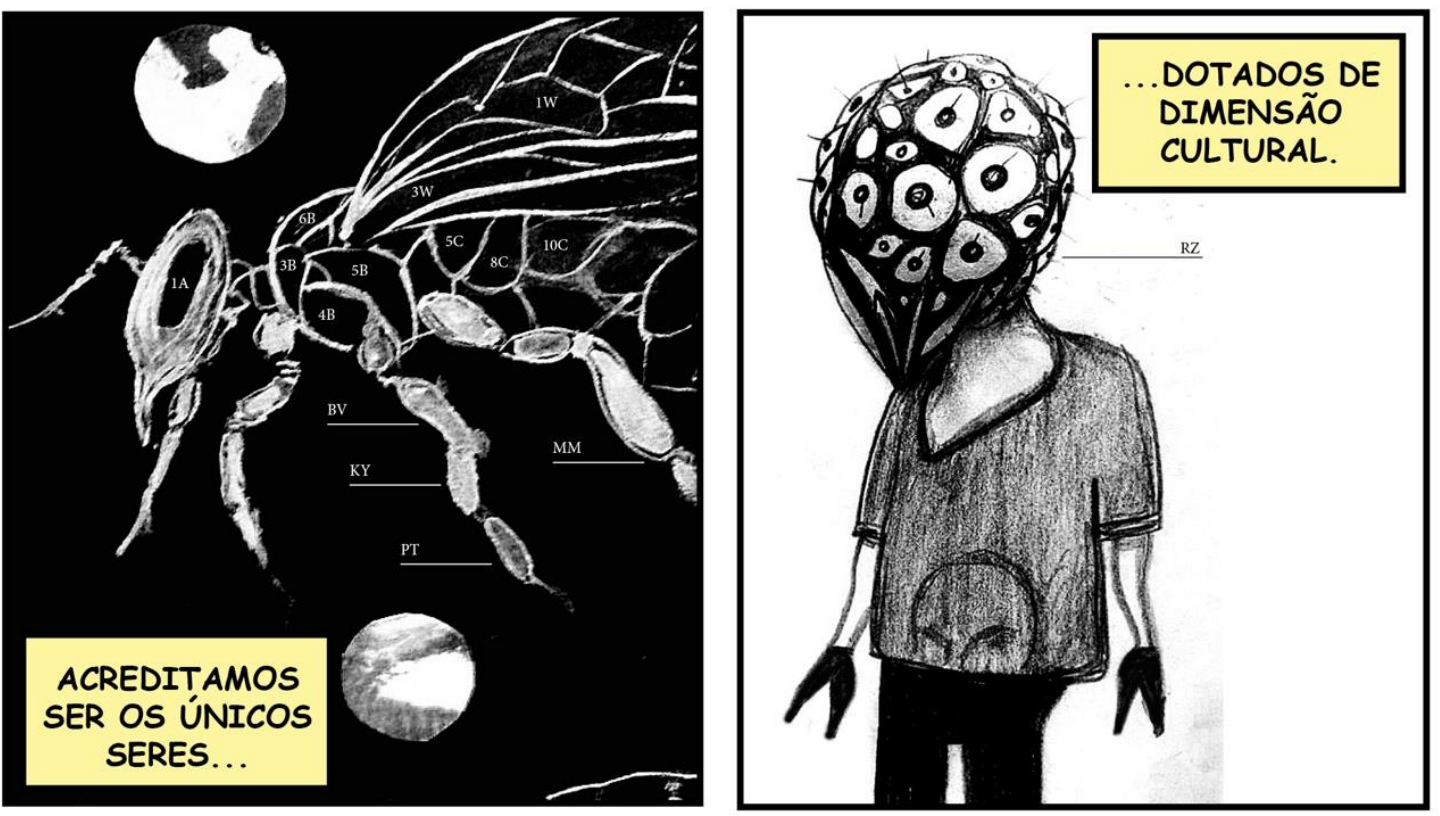

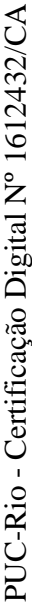

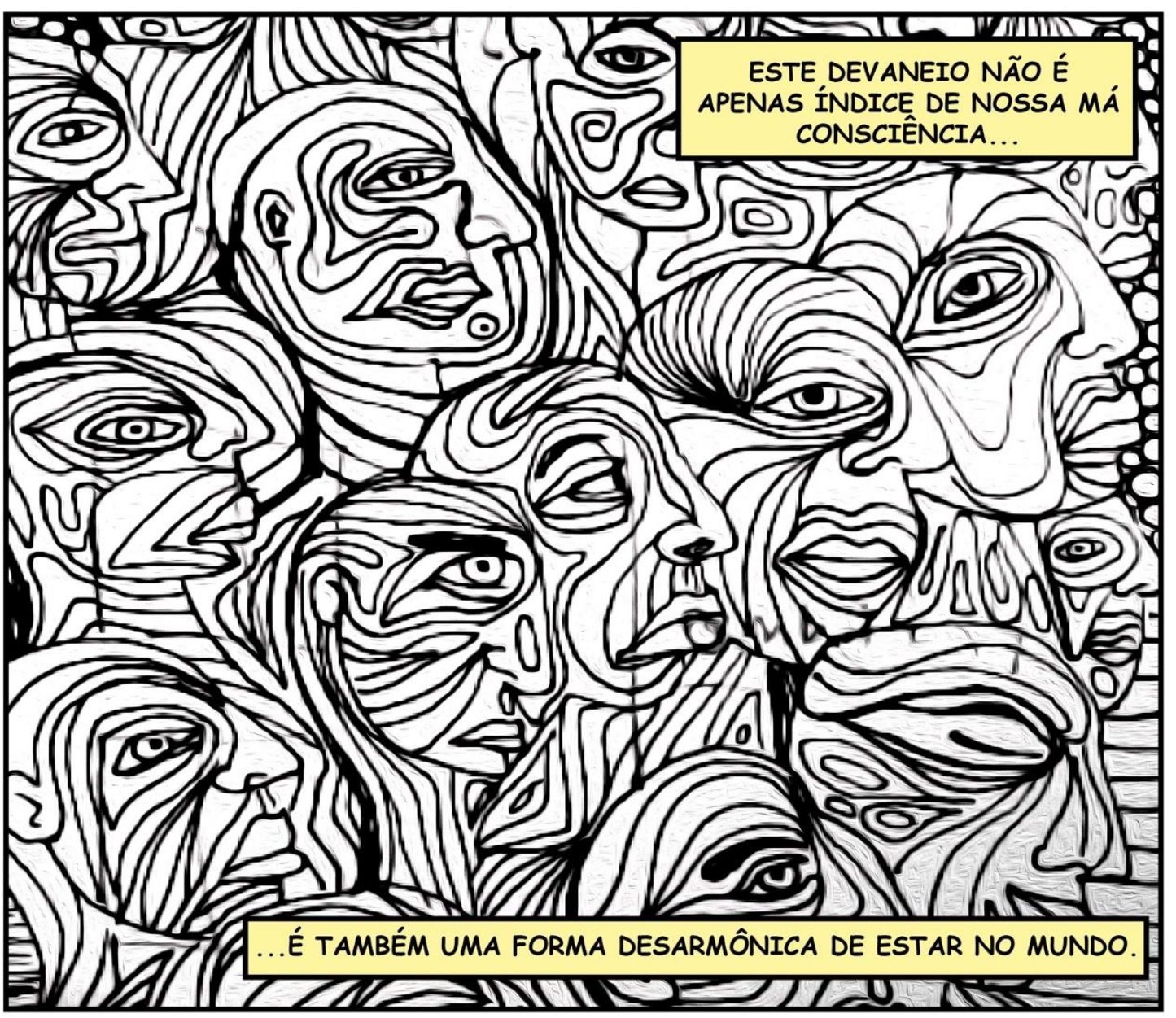




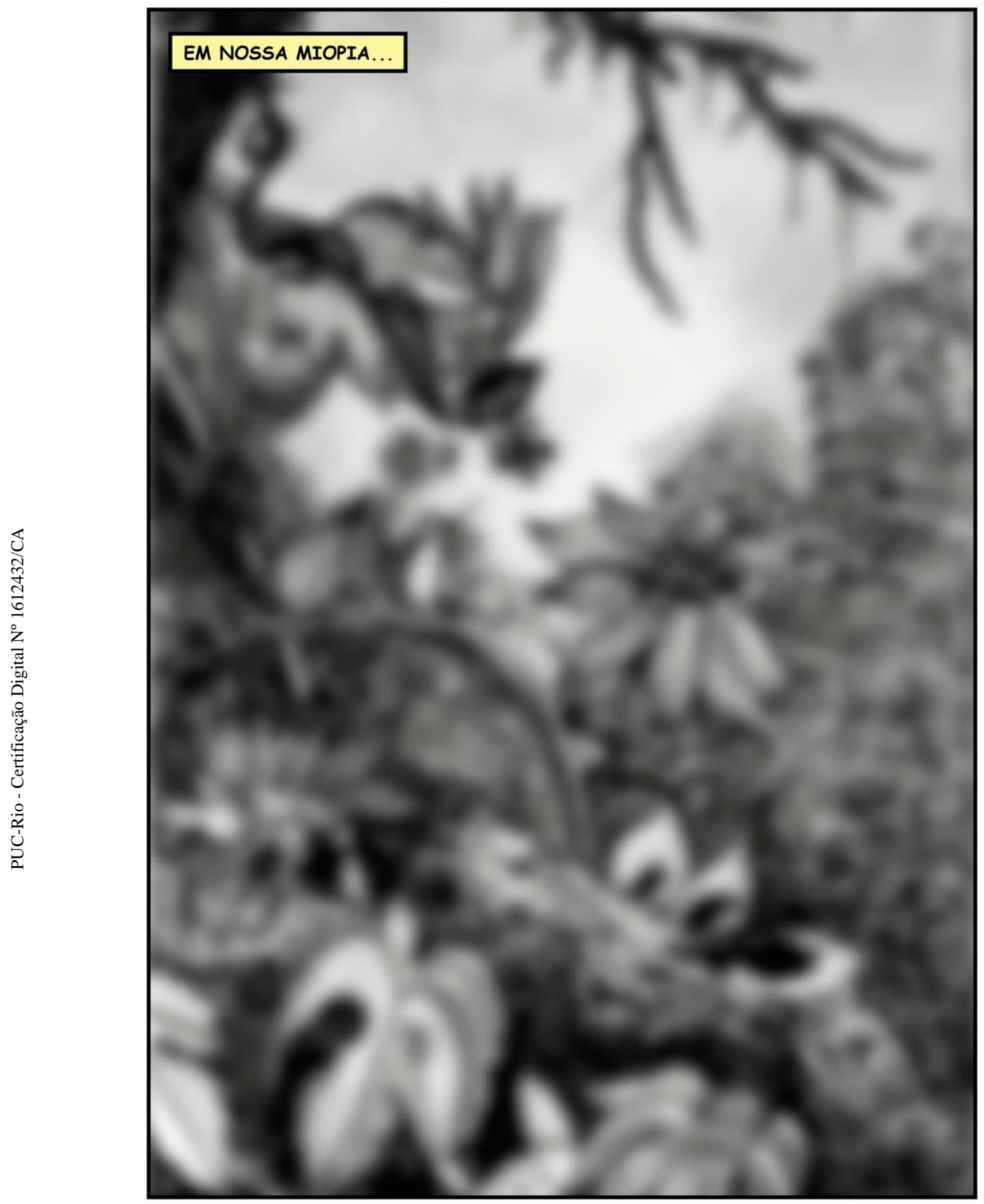




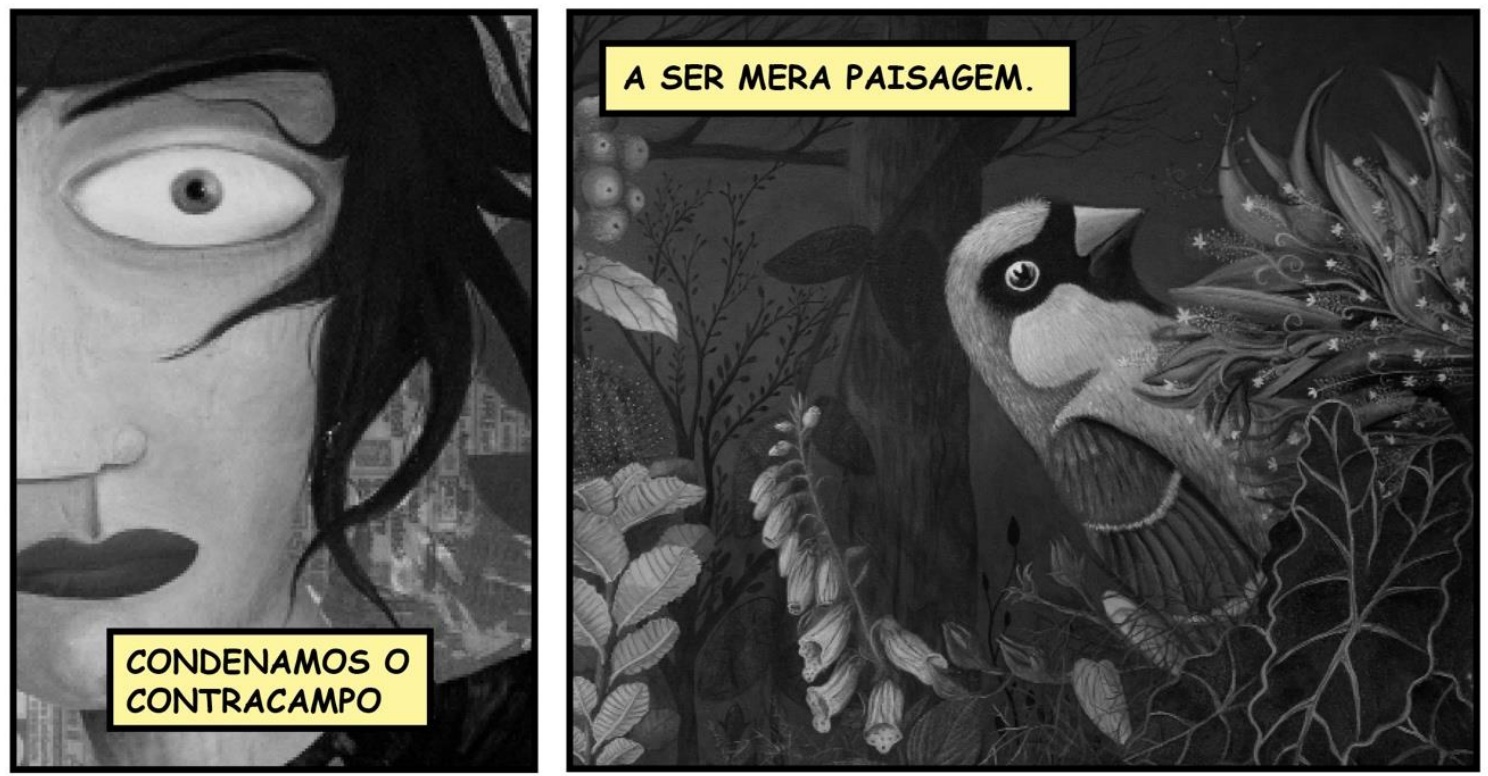

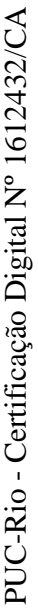

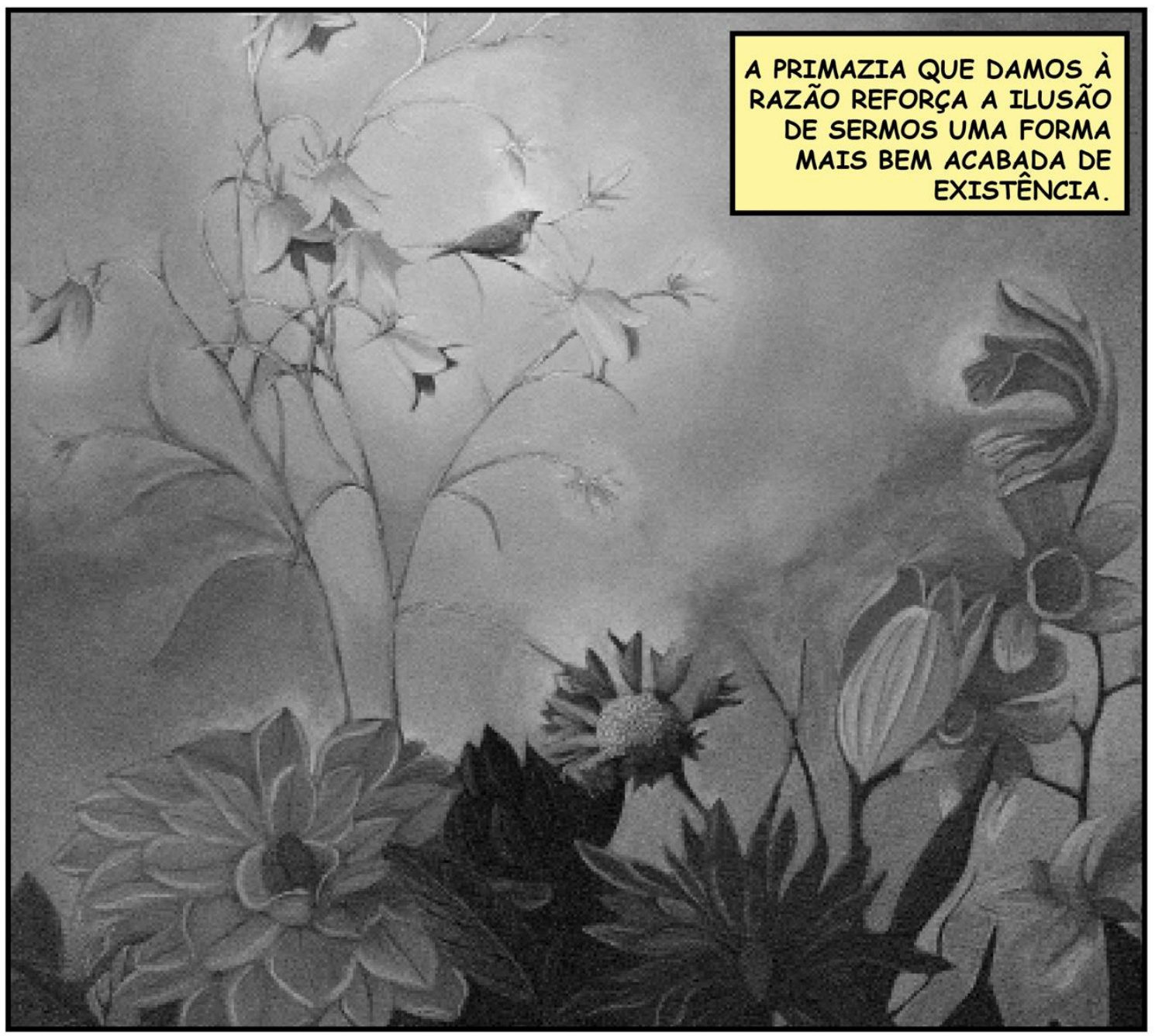



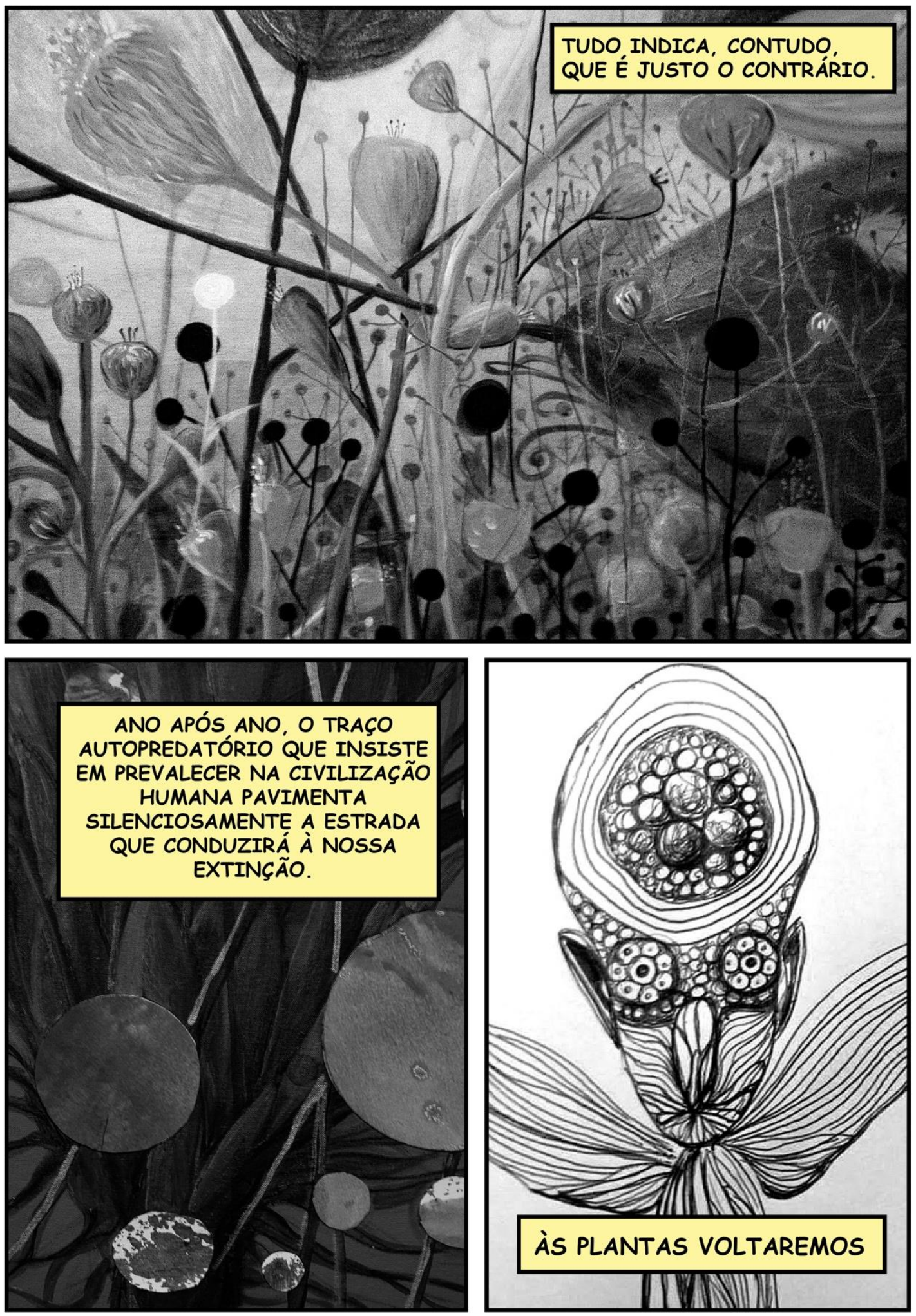


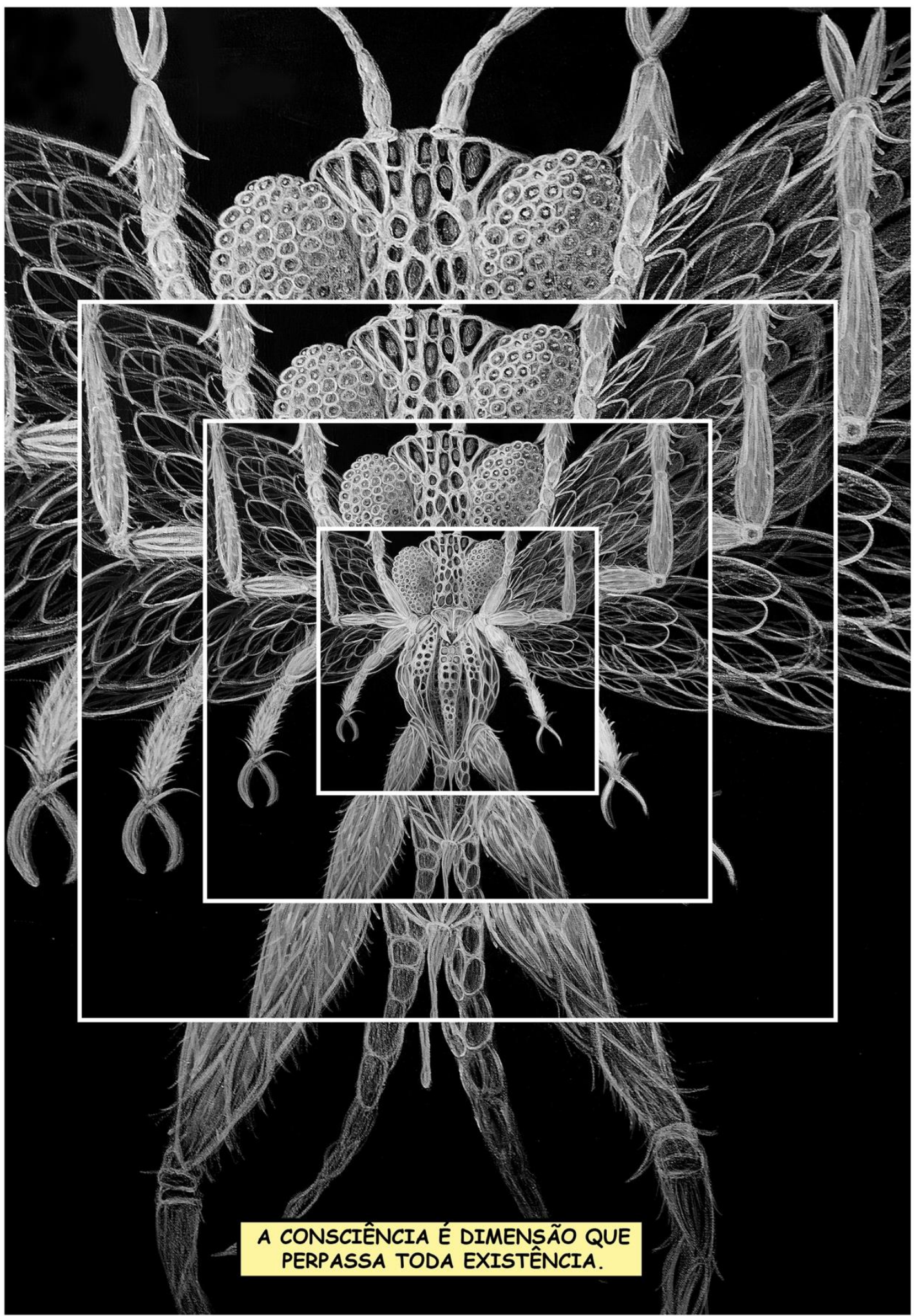



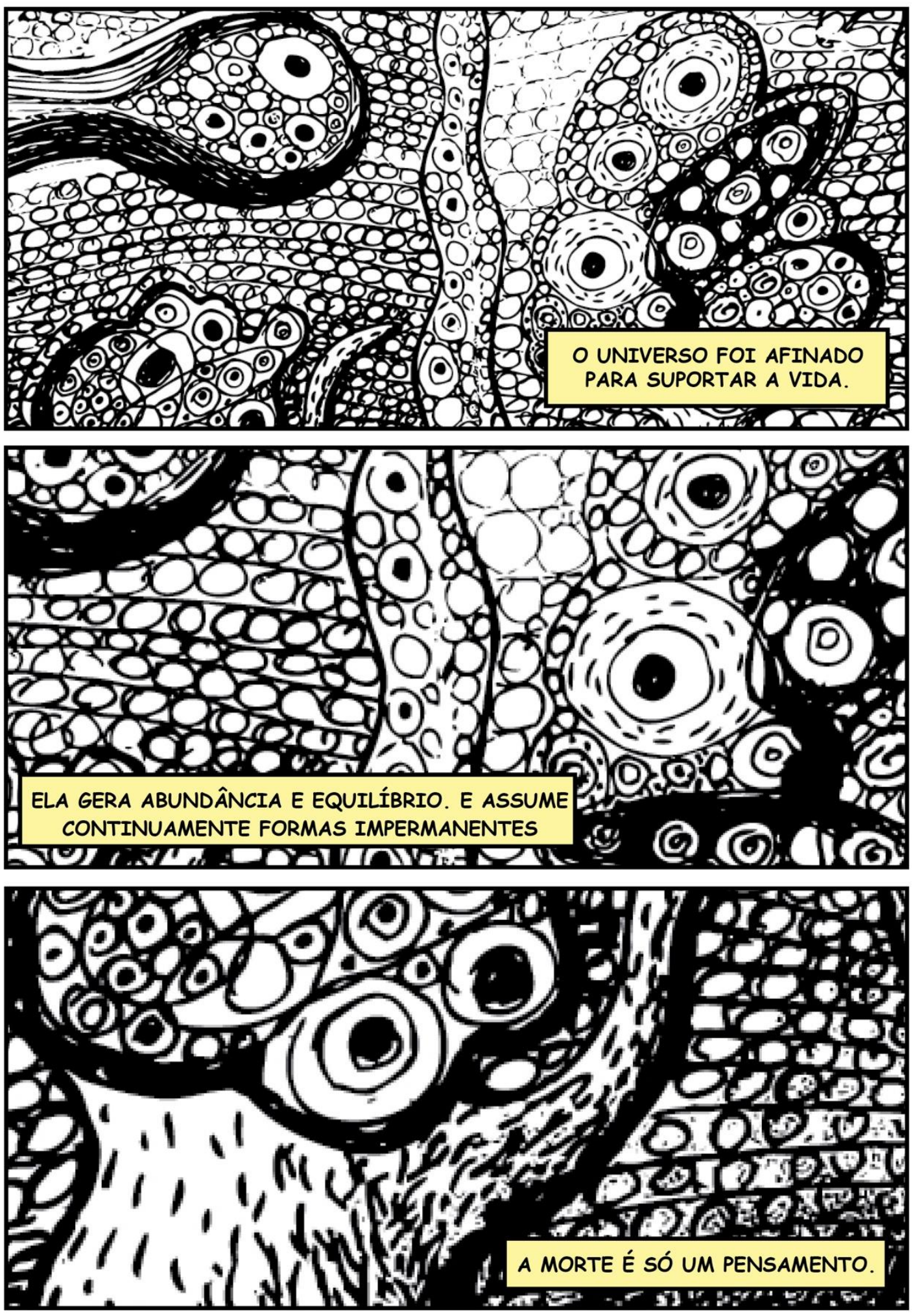
A CONSCIÊNCIA NÃO MORRE.

TRANSFORMA-SE, REAPRESENTA-SE, REMEDIA-SE EM OUTROS CORPOS

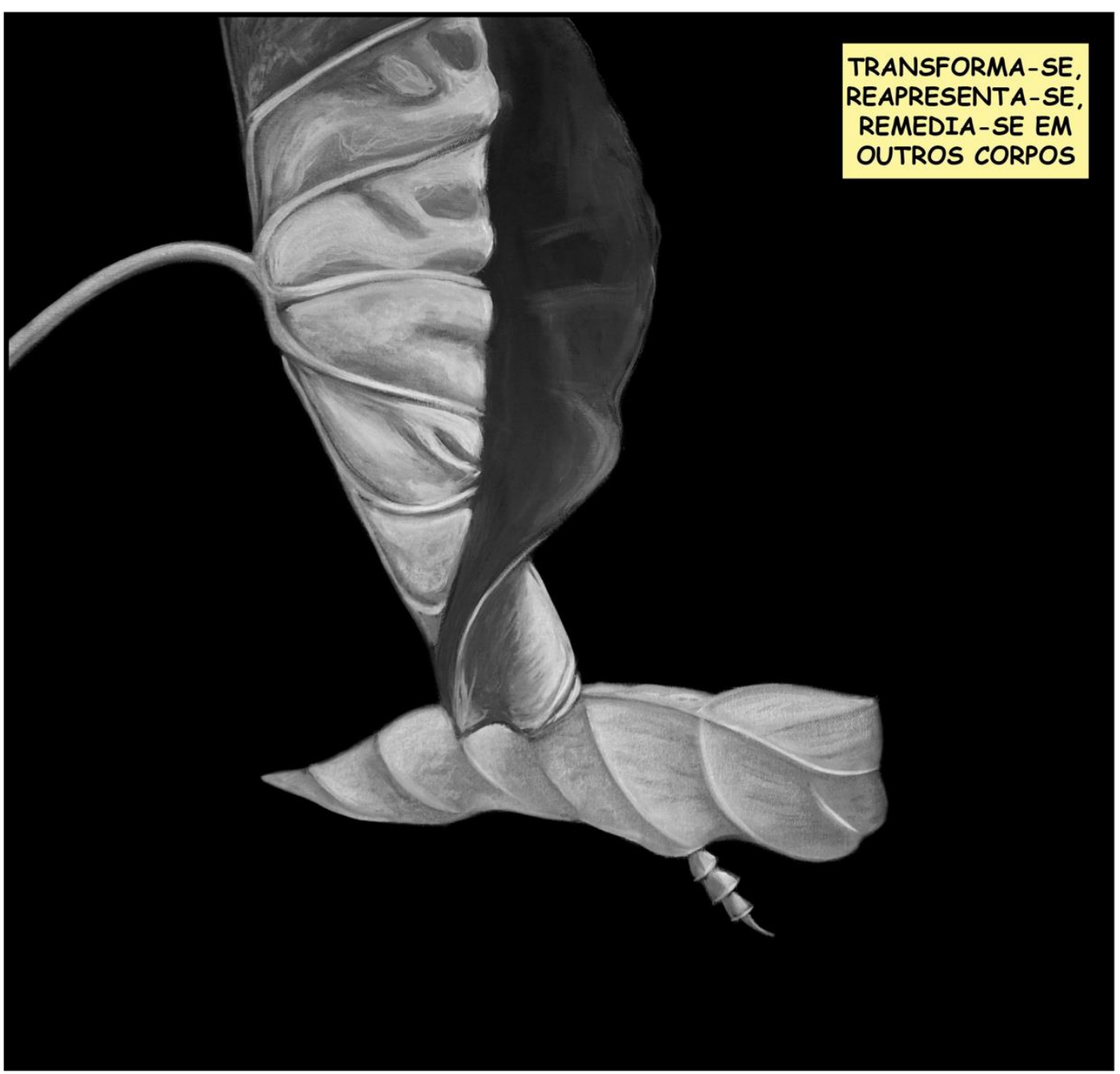




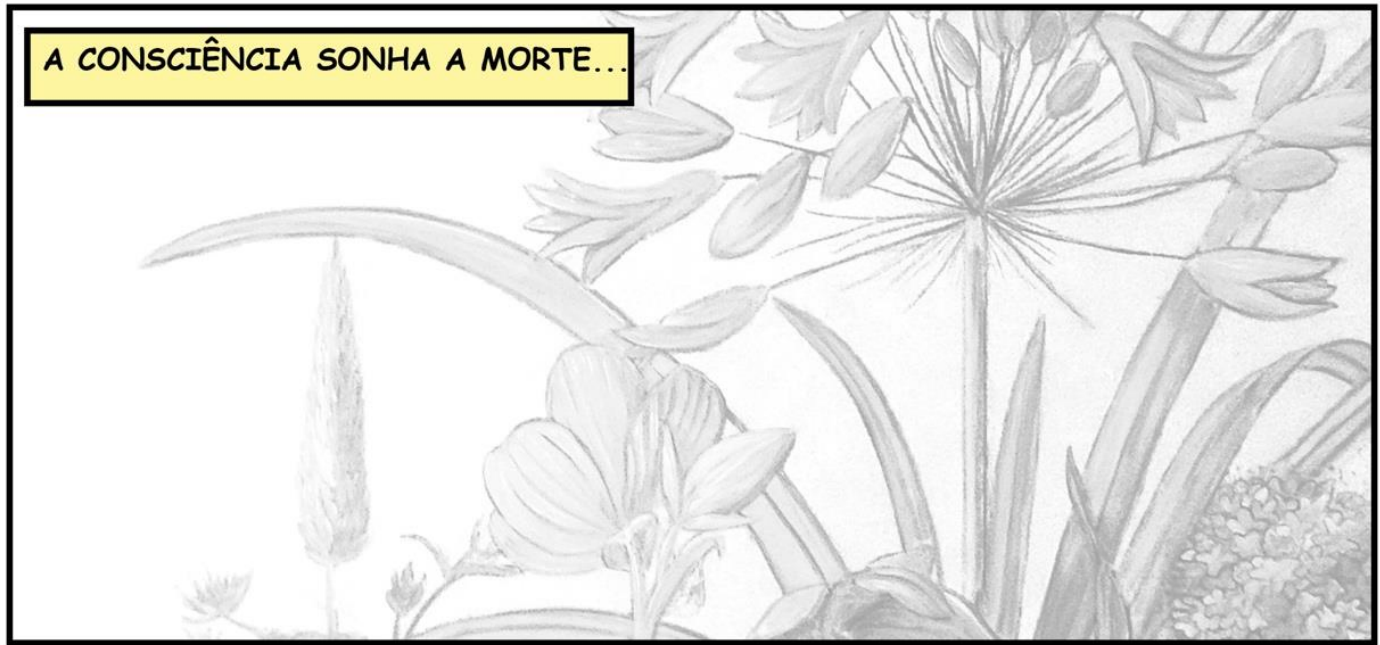

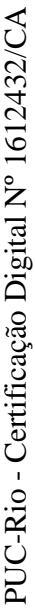
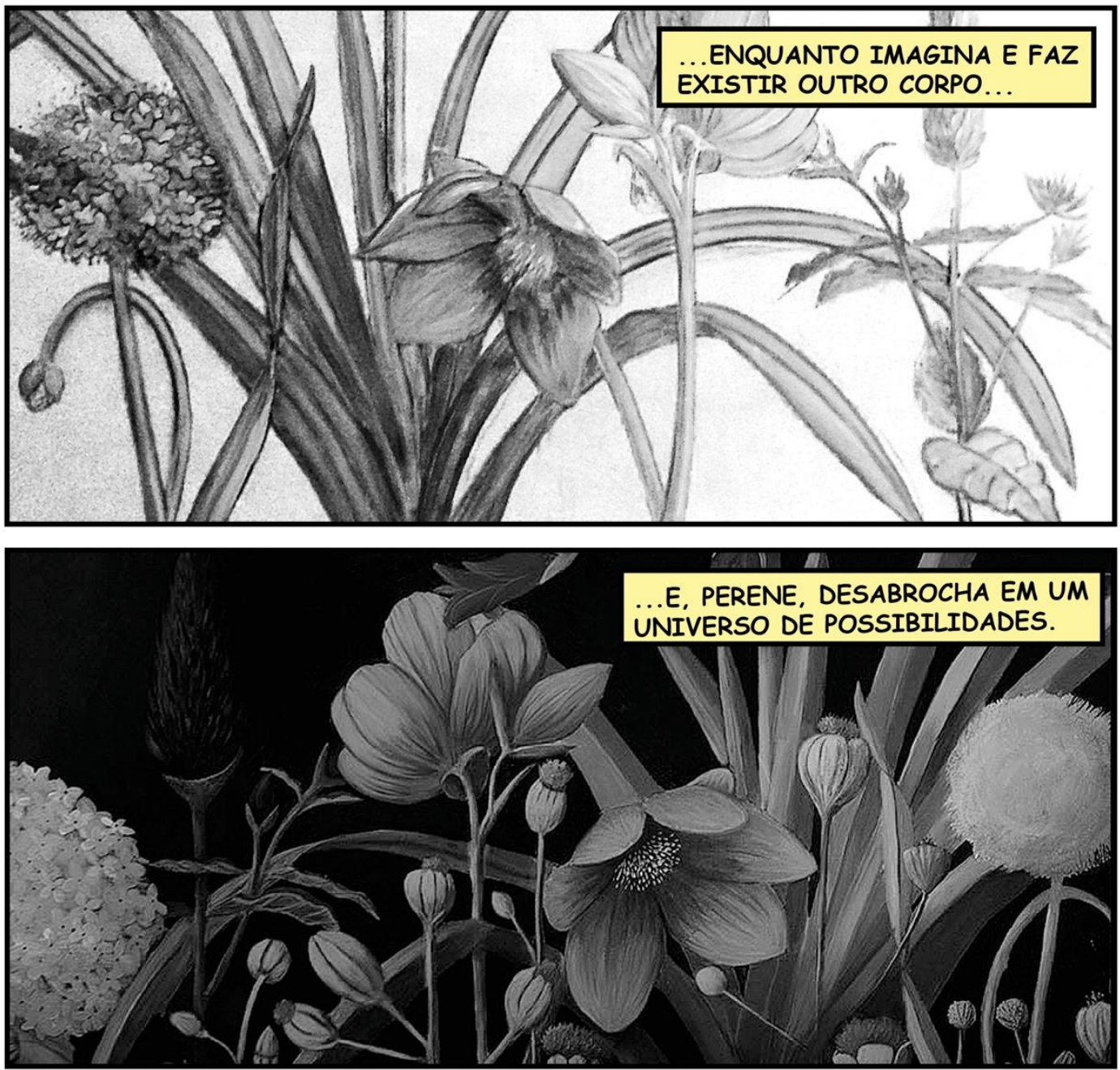

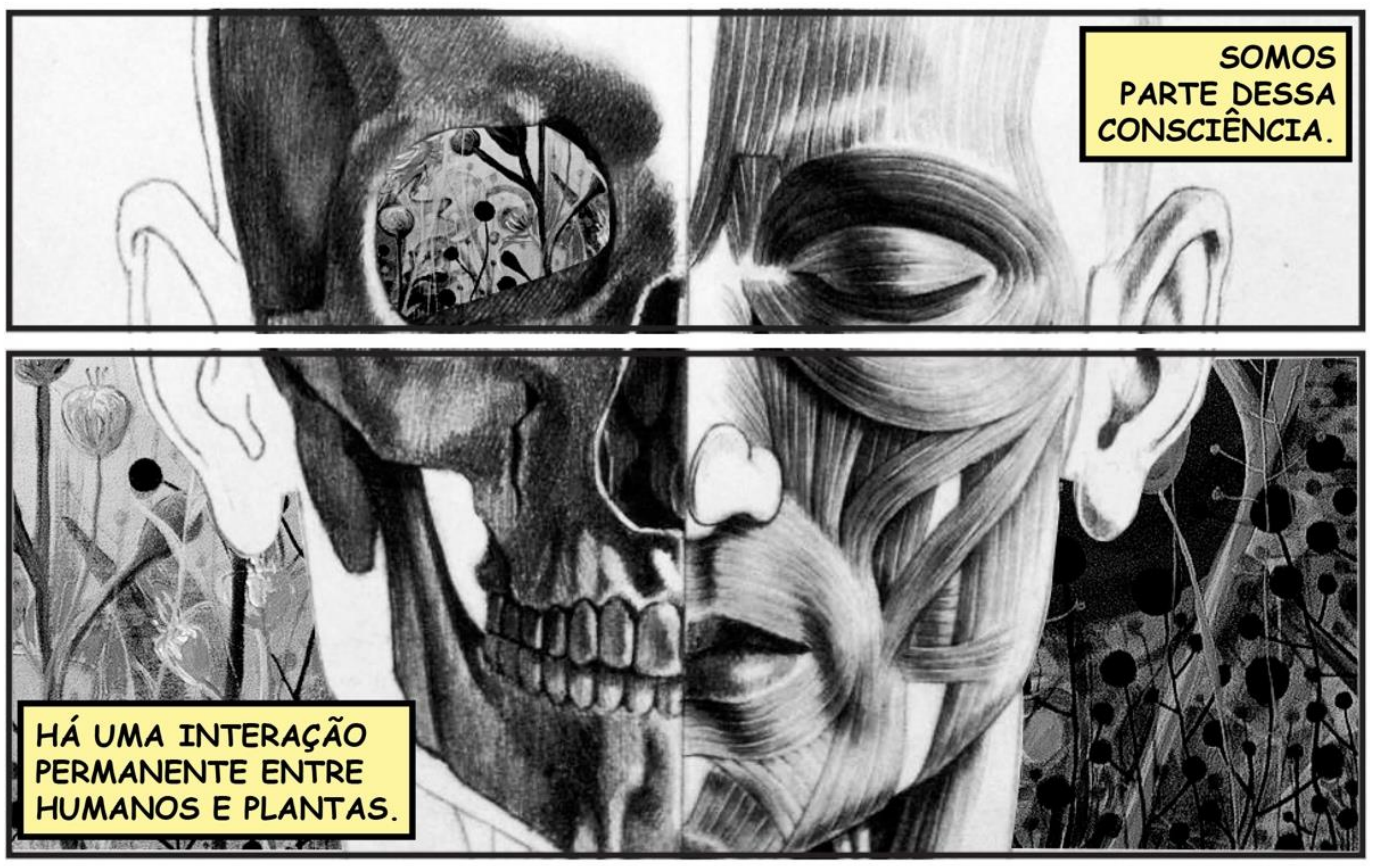

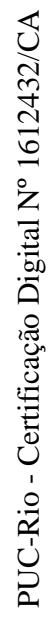

\section{PLANTAS TEM \\ CONSCIÊNCIA, \\ RECONHECEM-SE E \\ COMPETEM COM OUTRAS \\ ESPÉCIES.}

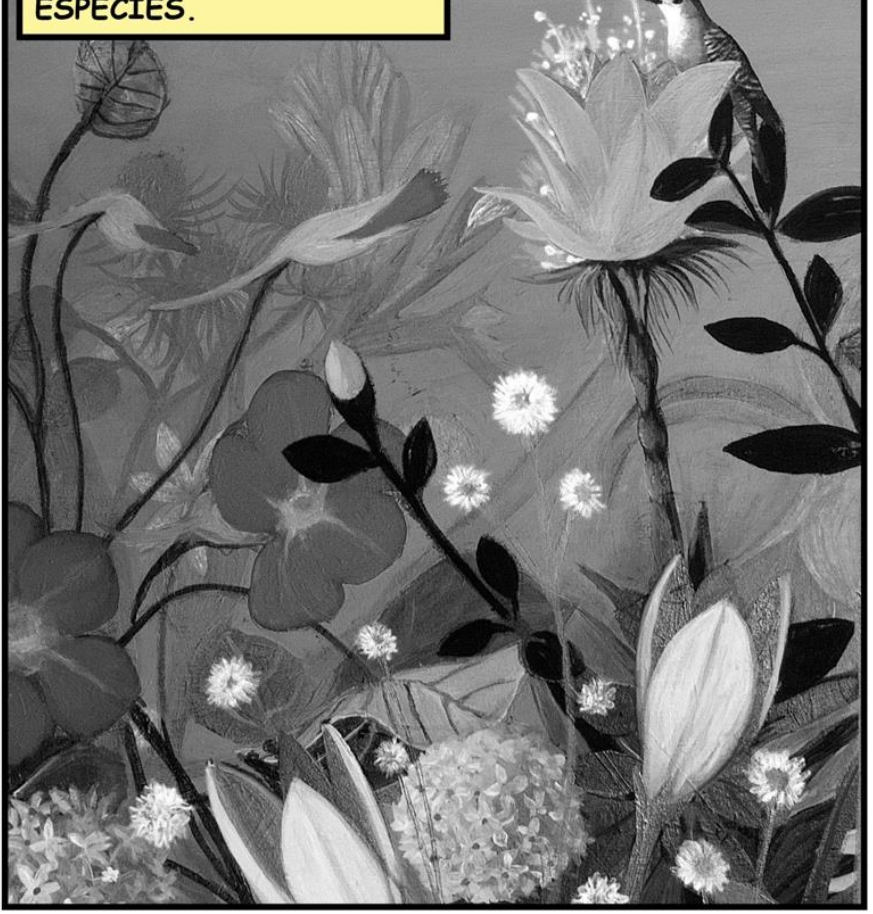

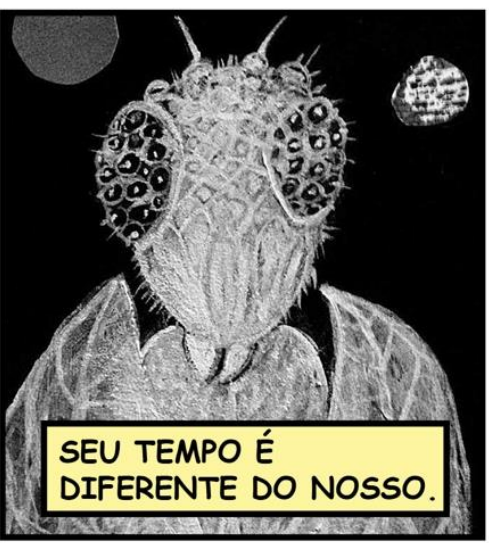

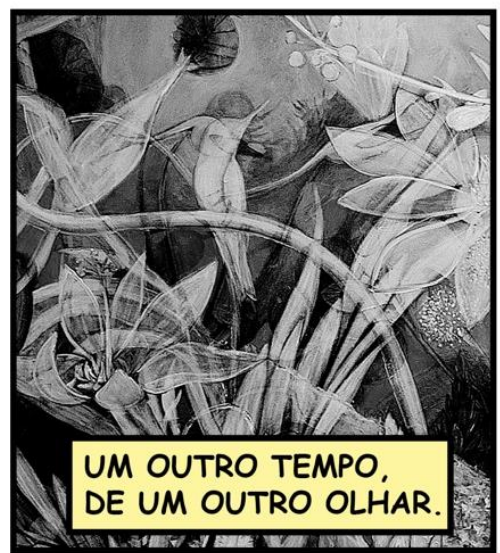


Uิ
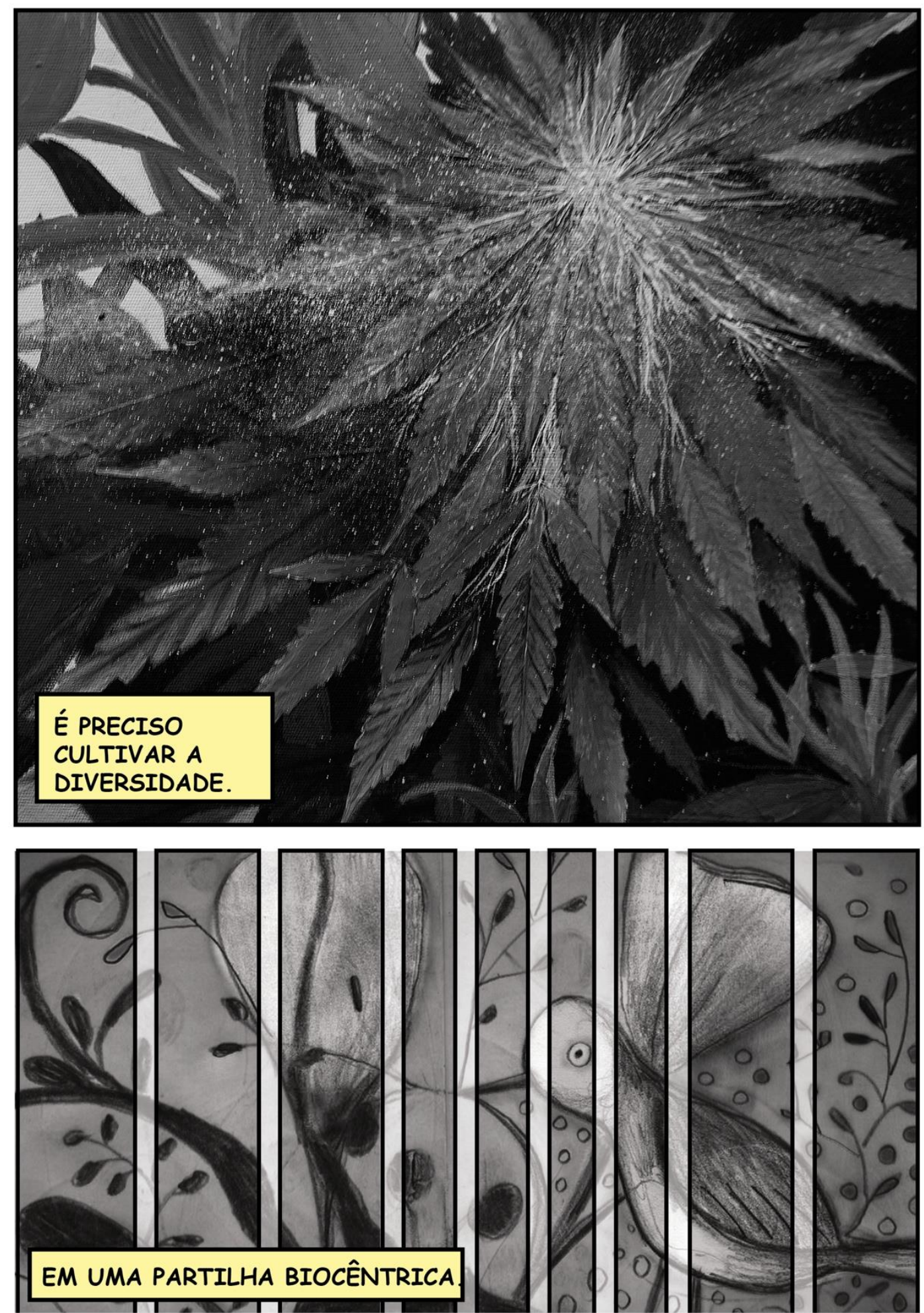

EM UMA PARTILHA BIOCÊNTRICA TI - MIIII 

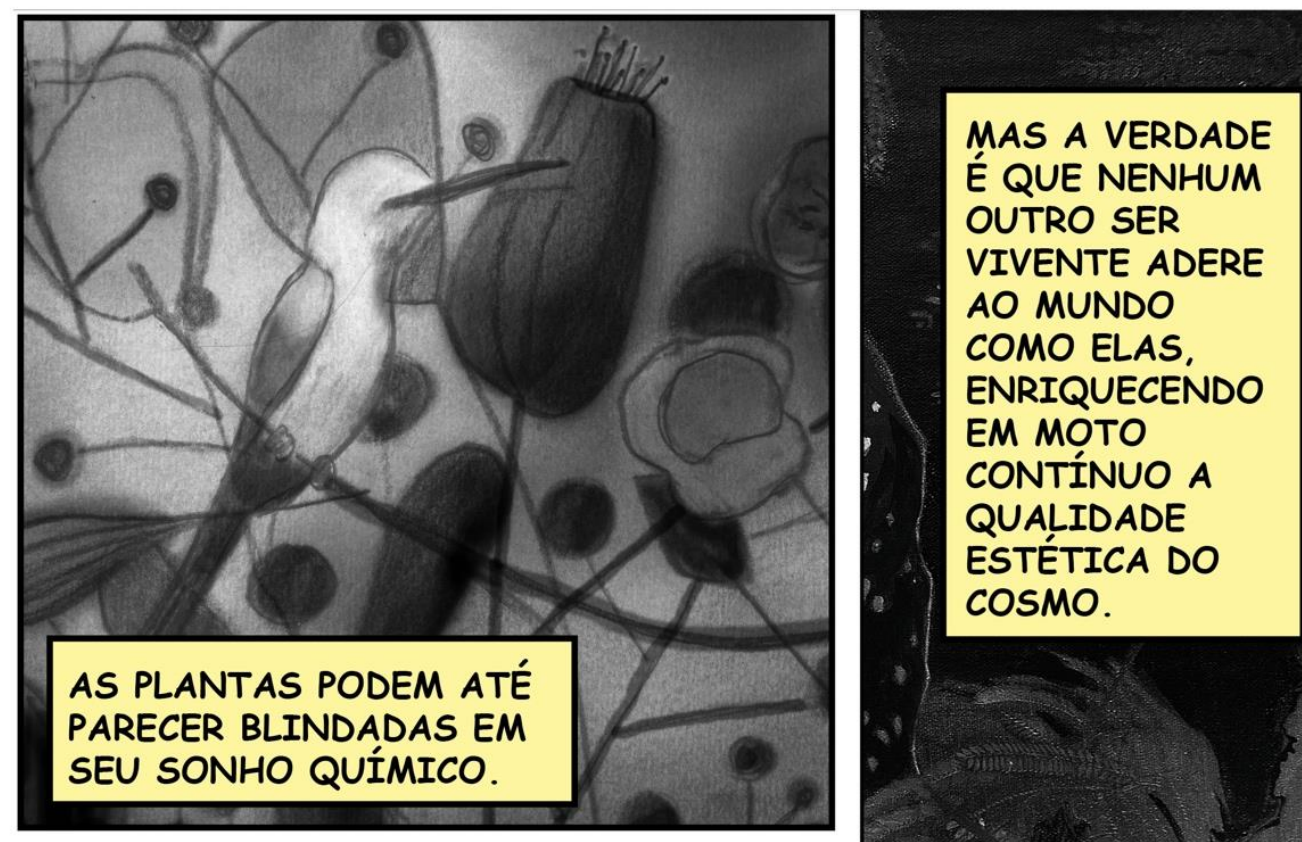

Uิ

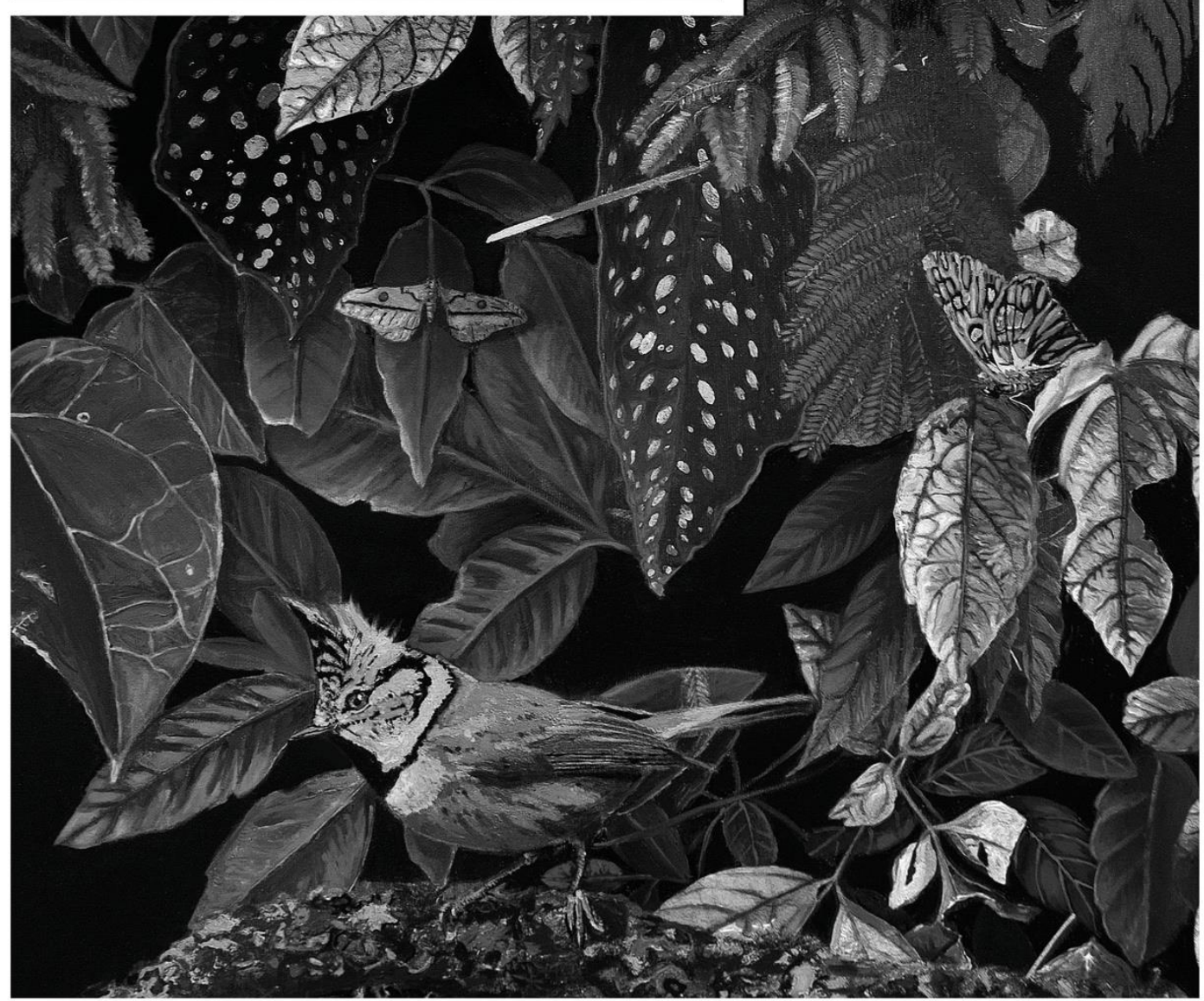




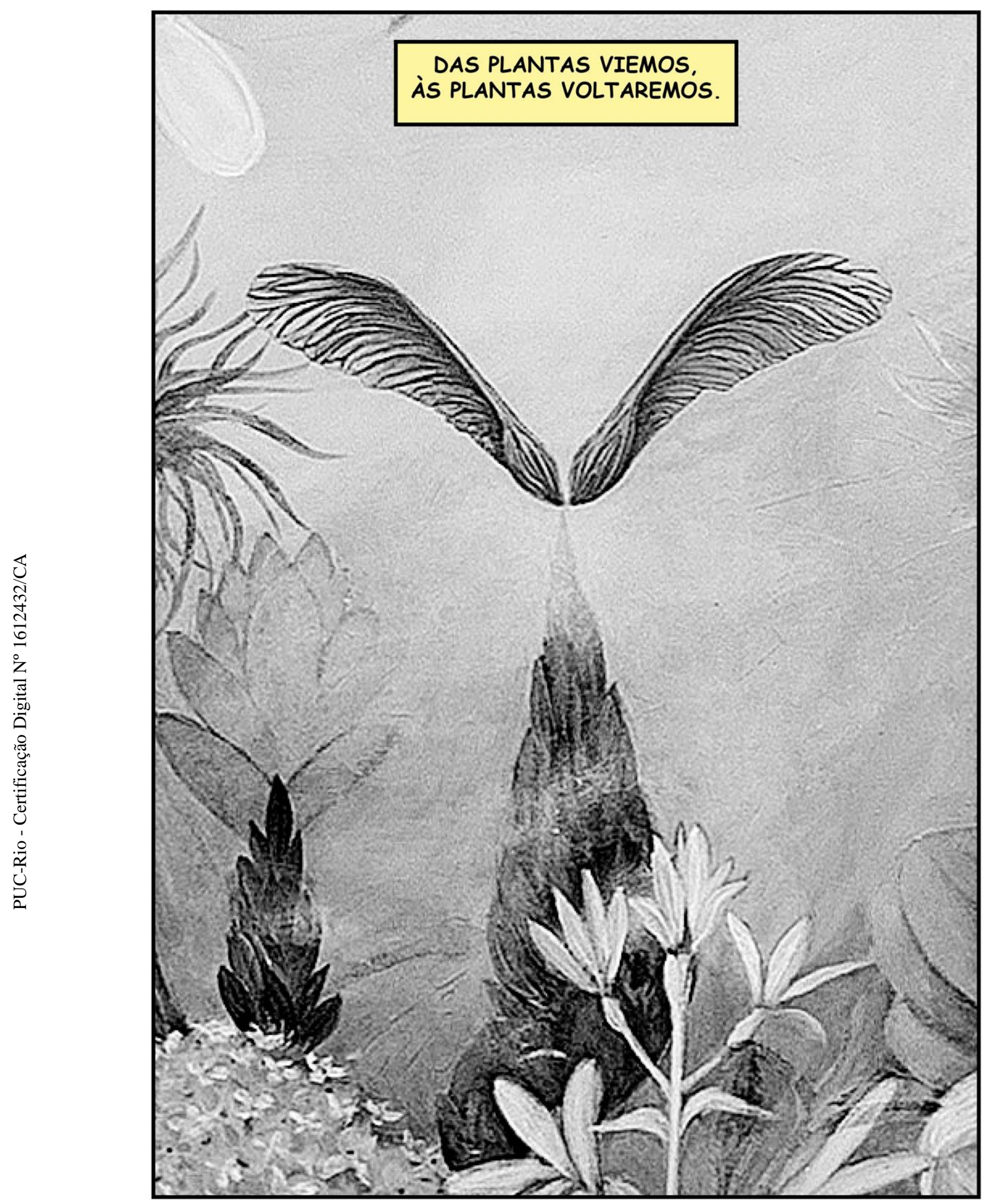




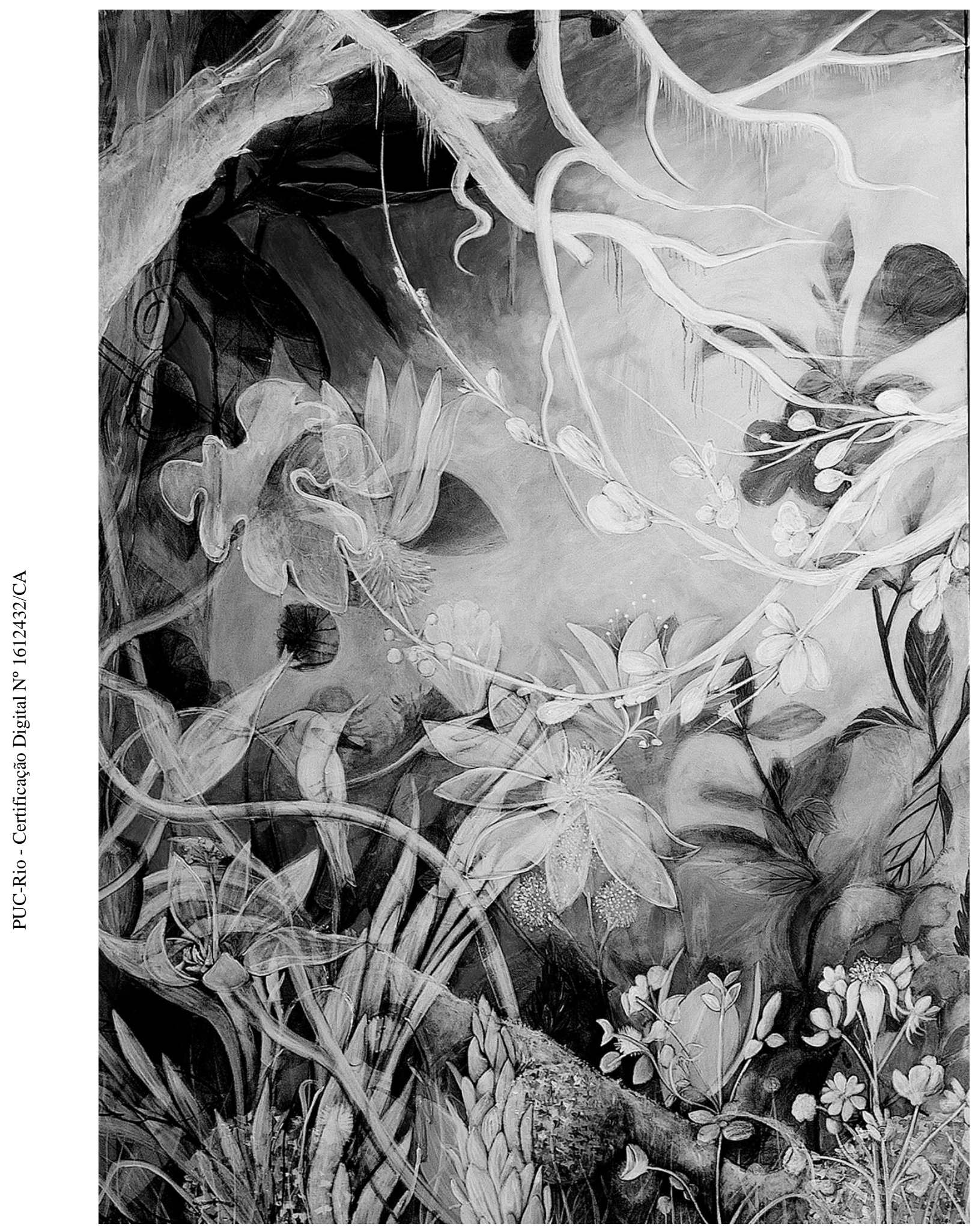




\section{6 \\ Conclusão}

O experimento teórico Jardim das sinapses constitui um exercício de remediação e partiu do desejo de recriar e reapresentar, no contexto gráfico de uma história em quadrinhos, um ensaio que, inicialmente, foi produzido para ter existência dependente - embora não justaposta - das pinturas, da série de mesmo nome, de Sergio Manon.

Escrito sob encomenda, o ensaio Jardim das sinapses logrou oferecer um olhar sobre as pinturas de Manon e talvez acompanhar algumas de suas exposições ou mesmo textos de assessoria de imprensa. A ideia de transpô-lo para os quadrinhos se deu, posteriormente, quando tomei conhecimento do envolvimento de longa data do artista com a linguagem dos quadrinhos. Parte integrante desta pesquisa, o ensaio gráfico biocêntrico só se realiza efetivamente como uma história em quadrinhos ao conseguir tornar transparente ou invisível a midialidade anterior de pintura e de texto ensaístico.

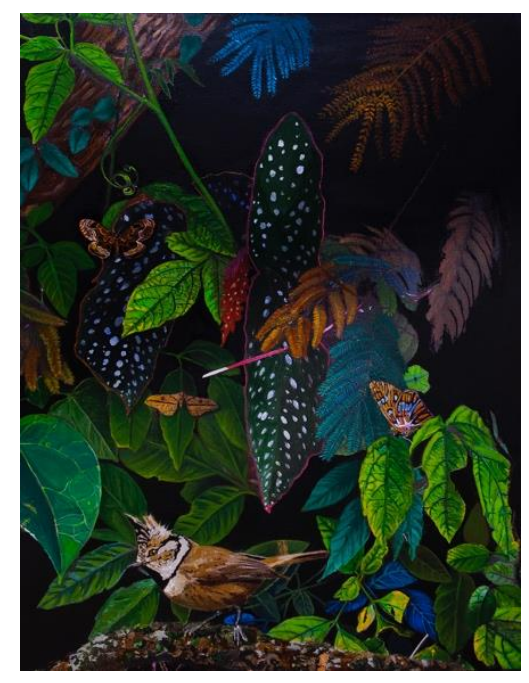

Figura 28 - Selvagem, pintura, técnica mista, acrílica / óleo, 80x60cm. 
Em etapa inicial, desenvolvi pesquisa visual no acervo de obras produzidas pelo artista; algumas delas já se encontravam vendidas e meu acesso a elas se deu apenas virtualmente, por meio de fotografias. Imprimi e recortei as imagens. Decupei o texto em fragmentos e recortei-os do papel espalhando-os sobre a mesa:

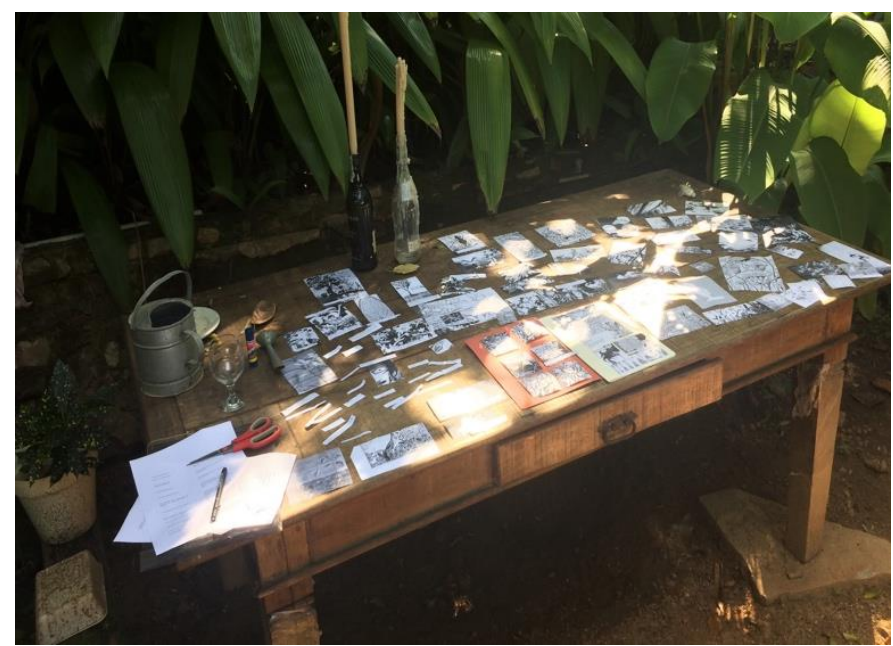

Figura 29- processo de montagem do Jardim das sinapses

O primeiro procedimento de montagem da Hq Jardim das Sinapses foi, portanto o de recorte e colagem, tanto do texto quanto da imagem. A coexistência espacial dos fragmentos - de frases e imagens - deu-me uma visão do todo que foi fundamental na organização do pensamento. Uma vez reunidos todos os fragmentos em um mesmo espaço, eu podia sem dificuldade associar e dissociar imagens e textos.

Em seguida peguei um caderno em branco, de 20 páginas e tamanho A4, e gramatura alta para suportar a cola, e o fui preenchendo, percebendo como os fragmentos se associavam no espaço da página. Essa etapa determinou boa parte das escolhas de montagem dos quadrinhos. 


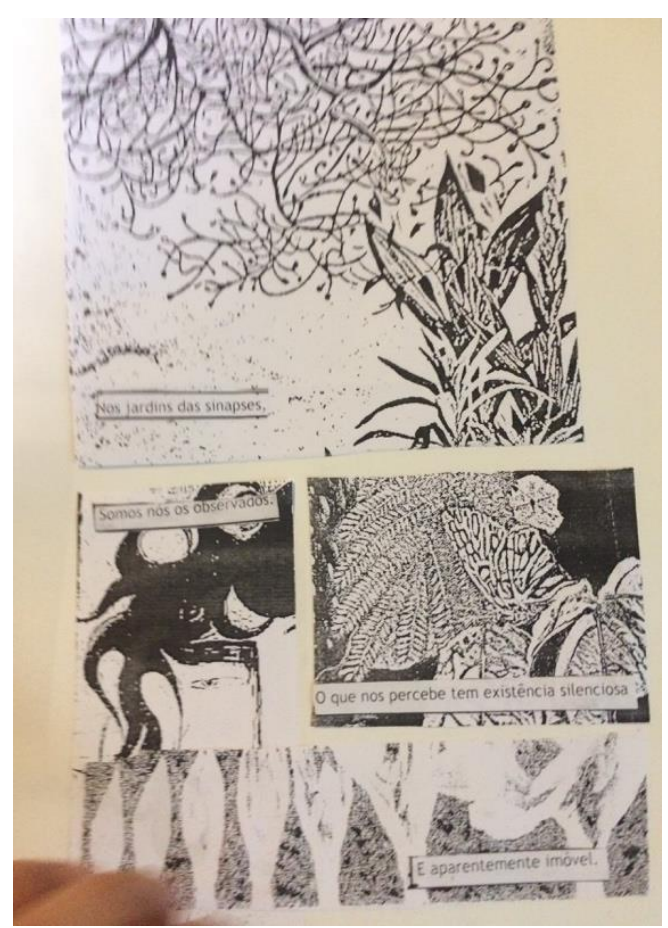

Figura 30 - processo de montagem do Jardim das sinapses

$\mathrm{O}$ uso do recurso digital nos permitiu dar às imagens um tratamento visual gráfico, graças à conversão das cores originais das telas que fotografamos para o preto e branco e ao ajuste de tonalidades.

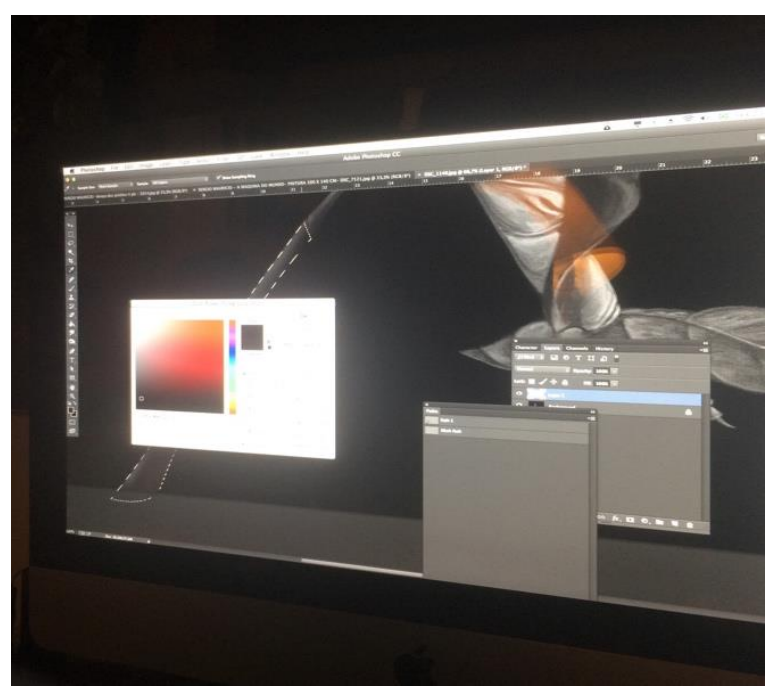

Figura 31 - processo de montagem do Jardim das sinapses 
Além disso, e não menos importante, foi também graças ao recurso de cortes e montagem que conseguimos encadear as imagens a serviço da narrativa que se buscou construir. A remediação das pinturas de Manon nos quadrinhos se deu concomitante à remediação do texto ensaístico para o campo fragmentado dos quadrinhos. A recriação do ensaio para o ambiente dos quadrinhos exigiu, portanto, cortes e edições do texto original. Demandou, sobretudo, que, em diálogo com a imagem, parte do texto fosse posto em silêncio na intenção de fazer falar as imagens. A premissa de que não é necessário (e, menos ainda, desejável) mostrar tudo leva à questão do que é efetivamente importante mostrar, que elementos de uma cena fornecem os detalhes necessários para levar o leitor em direção ao que é mais fundamental afastando do desnecessário e do redundante.

As partes do ensaio que faziam referência direta ao artista visual e seu processo de pesquisa também foram modificadas pois não se adaptavam ao propósito do novo contexto que era criar uma história a partir da narrativa biocêntrica. Na reapresentação (na remediação) do ensaio pelos quadrinhos, não se buscou, contudo, eliminar essas referências, mas, antes, posicioná-las no prefácio e fazer com que falassem indiretamente através da obra tornada sequencial e ficcionalizada.

Assim sendo, a recriação do ensaio e sua justaposição com as imagens em sequência narrativa demandou não uma operação de simples exclusão de textos e edição de imagens, mas, sim, uma operação de reequilíbrio desses elementos, a partir do objetivo que se apresentava. Importante ressaltar que os elementos narrativos não estiveram a serviço da narrativa clássica - a ausência de protagonismo de um único personagem, a ausência de balões de fala ou mesmo a ausência de um objetivo de ação (ou unidade de ação) para os personagens, por exemplo, são indicativos de um caminho que pretendeu acentuar o traço experimental do trabalho, distanciando-o de muitas convenções já consolidadas na linguagem dos quadrinhos.

No Jardim das sinapses, o personagem central são vários, e não um. O protagonista é coletivo, são as plantas. O narrador está entre os humanos e fala em primeira pessoa - "somos nós os observados" - mas destitui-se de um lugar de destaque, para reconhecer-se apenas parte de um todo cuja complexidade intrigante 
e perfeita lhe excede. A natureza - antes, percebida como mera paisagem, uma espécie de contracampo passivo - agora nos observa; enquanto em tom autocrítico o narrador humano (um "nós") faz-nos reconhecer nossas delusões e nossa inserção em um sistema vital (biocêntrico) mais abrangente, no qual somos levados a reconhecer não estarmos no centro.

A justificativa para propor o experimento teórico Jardim das sinapses nesta dissertação apresenta-se em duas instâncias diferentes: a primeira faz claramente referência ao tema desta dissertação, a intermidialidade e a remediação da pintura e seus textos para o contexto gráfico dos quadrinhos. Ao utilizar as pinturas de Manon - que, no contexto das galerias, têm o status e o valor de obra de arte - no contexto de um trabalho gráfico, esta pesquisa traz para o plano prático da experimentação o tema da remediação da pintura e seus textos pelos quadrinhos, pois nos foi necessário repensar a existência dessas imagens, doravante justapostas a fragmentos de textos, modificadas em seu contexto, alteradas em suas cores, em seus tamanhos. O mesmo se pode dizer, embora em outra medida, em relação ao ensaio, cuja totalidade e propósito também sofreu modificações a fim de se adaptar ao contexto narrativo e poético do ensaio gráfico. Interessante notar que, em via de mão dupla, também a visão do artista sobre sua obra foi sensibilizada de um modo diferente. Acentuou-se a relação entre suas telas a partir do exercício constitutivo do ensaio gráfico de tecer um fio narrativo entre seus trabalhos.

A segunda instância revela-se na estratégia de investir em relações de metalinguagem ao longo do ensaio gráfico a fim de relacionar de modo poético o tema do biocentrismo ao tema da intermidialidade. O biocentrismo, como linha de pesquisa de investigação desenvolvida pelo cientista norte-americano Robert Lanza, sustenta entre outras coisas, a hipótese da reencarnação. Segundo Lanza, os corpos são meios a partir dos quais uma grande consciência assume temporariamente uma forma, existindo nesse contexto subordinada a certas condições do corpo que habita. A morte, na visão do cientista seria pura ficção de um estado temporário da consciência. Quando no texto se disse que a vida "assume continuamente formas impermanentes" procurou-se trabalhar de forma poética em associação com a própria ideia de que a expressão artística apresenta formas e recursos distintos conforme a materialidade da mídia em que se manifesta. Da 
mesma forma, a ideia de que a consciência não morre, e, sim, se remedia em corpos diferentes traz o mesmo sentido de um comentário metalinguístico. 


\section{Referências bibliográficas}

AMIEL, Vincent. Estética da montagem. Editora Texto e grafia, 2010.

BARBOSA, João Alexandre Barbosa. A leitura do intervalo. São Paulo: Iluminuras; Secretaria de Estado da Cultura de São Paulo, 1990

Alguma crítica. São Paulo: Editora Atelier, 2002.

BIBE-LUYTEN, Sonia. O que é história em quadrinhos. São Paulo: Brasiliense, 1993.

CAMPBELL, Eddie. Eddie Campbell's Graphic Novel Manifesto. Disponível

em: < http://donmacdonald.com/2010/11/eddie-campbells-graphic-novel-

manifesto/ >

CHINEN, Nobu; RAMOS, Paulo; VERGUEIRO, Valdomiro (orgs). Os pioneiros no estudo de quadrinhos no Brasil. São Paulo: Criativo, 2013

CIRNE, Moacy. Por que ler os quadrinhos. In: MOYA, Álvaro de; CIRNE, Moacy (org.). Literatura em quadrinhos no Brasil: Rio de Janeiro: Nova Fronteira; Fundação Biblioteca nacional, 2002.

CLÜVER, Claus. Intermidialidade. Revista Pós: Belo Horizonte. v. 1, n.2, p. 523, nov 2011.

Intermidialidade e Estudos Interartes. In: NITRINI, Sandra; PEREIRA, et alli (org.). Literatura, artes, saberes. São Paulo, SP: Editora Hucitec, 2008. p. 209 -232 .

Inter textus / inter artes / inter media. Aletria: Revista de Estudos de Literatura, v. 14, dez, 2006.

COCA, Adriana Pierre. As subversões cronotópicas na microssérie Capitu. Revista Temática, v. 14, n. 3 (2018), Ed. UFPB, Paraíba,

COCCIA, Emanuele. A vida das plantas. Florianópolis: Cultura e barbárie, 2018. DINIZ, Thais flores Nogueira; VIEIRA, André Soares. Intermidialidade e estudos interartes. Desafios da arte contemporânea. Belo Horizonte: Editora Rona; FALE UFMG, 2012.

EISNER, Will. Quadrinhos e arte sequencial: princípios e práticas do lendário cartunista. São Paulo: Martins Fontes, 2015.

GORENDER, Mirian. De que são feitos os quadrinhos. In Revista Universitária do Audiovisual. Dezembro, 2008.

GROENSTEEN, Groensteen. O sistema dos quadrinhos. São Paulo: Editora Marsupial, 2015.

GUMBRECHT, Hans Ulrich. Produção de presença - o que o sentido não consegue transmitir. Editora Contraponto. PUC Rio, 2010.

O campo não hermenêutico ou a materialidade. Teresa: Revista de Literatura Brasileira [10|11]; São Paulo, p. 386-407, 2010.

JOST, François. Das virtudes heurísticas da intermedialidade. Cerrados: Revista do Programa de Pós-Graduação em Literatura da UNB, Brasília, n. 21, ano 15. p. 33-45. 2006.

JUNIOR, Gonçalo. A guerra dos gibis. São Paulo: Editora Cia das Letras, 2004. LEFÈVRE, Pascal. Ontologias visuais incompatíveis? A 
adaptação.problemática de imagens desenhadas. In: DINIZ, Thaís Flores Nogueira (. Org.) Intermidialidade e estudos interartes: desafios da arte contemporânea. Belo Horizonte: Editora UFMG, 2012. p. 189-207.

MACHADO, Arlindo. Arte e mídia. 3.ed. Rio de Janeiro: Jorge Zahar, 2010.

MANGUEL, Alberto. Imagem como ausência. In: Lendo imagens. Tradução: Rubens Figueiredo, Rosaura Eichemberg, Cláudia Strauch. São Paulo: Cia da Letras, 2001.

MCCLOUD, Scott. Desvendando os quadrinhos. São Paulo: Ed. M Books, 2004. Reinventando os quadrinhos. São Paulo: Ed M Books, 2006.

MELO, Marques de. Da Gibimania à quadrinhologia. In MELO, Marques de; CHINEN, Nobu; RAMOS, Paulo; VERGUEIRO, Valdomiro (orgs). Os pioneiros no estudo de quadrinhos no Brasil. Ed. Criativo, São Paulo, 2013. P.12-27.

MENDES, João Maria. Introdução às intermedialidades. Centro de Investigação em Artes e Comunicação. Escola Superior de Teatro e Cinema. Universidade de Algarve. Portugal, 2011.

MOSER, Walter. As relações entre as artes: por uma arqueologia da intermidialidade. Aletria: Revista de Estudos de Literatura, [S.1.], v. 14, p. 42-65, dez. 2006. ISSN 2317-2096.

Estudo literários, estudos culturais: reposicionamentos. Literatura e Sociedade, n. 3 (1998). Editora da Universidade de São Paulo. Faculdade de Filosofia, Letras e Ciências Humanas.

MOYA, Álvaro de. História da história em quadrinhos. São Paulo: Brasiliense, 1993.

OLIVEIRA, Solange Ribeiro de. A literatura e as outras artes, hoje: um título, três problemas. Scripta Uniandrade, Curitiba, n. 5, p. 11-21, 2007.

RAJEWSKY, Irina O. Intermidialidade, intertextualidade e "remediação": uma perspectiva literária sobre intermidialidade. In: DINIZ, Thaïs Flores Nogueira (Org.). Intermidialidades e estudos interartes: desafios da arte contemporânea. Belo Horizonte: UFMG, 2012.

RAMOS, Paulo e FIGUEIRA, D - Graphic novel, narrativa gráfica ou romance gráfico? Terminologias distintas para um mesmo rótulo. Anais das II Jornada de Estudos sobre Romance, 2011.

RANCIÈRE, Jacques. Aisthesis: scenes from the aesthetic regime of art. Ed Verso, London, 2013.

SILVA, Fabio Luiz Carneiro Mourilhe. Quadro nos quadrinhos. Editora Multifoco, Rio de Janeiro, 2010.

SMITH, Matthew; DUCAN, Randy. The Secret Origins of Comics Studies. New York. Ed. Routledge, 2017.

STERZI, Eduardo. História, ensaio, intervalo Os lugares da crítica e da literatura em João Alexandre Barbosa. Universidade Estadual de Campinas.

VERGUEIRO, Waldomiro, RAMOS, Paulo e CHINEN, Nobu. Os Pioneiros no Estudo de Quadrinhos no Brasil. São Paulo: Editora Criativo, 2013.

WIVEL, Matthias. Töpffer and the Reinvention of Comics in the First Half of the 19th Century. In Articles and Essays and comics and cartooning, 2007. Disponível em: 〈http://www.metabunker.dk/?p=768> 